Pontifícia U U Uiversidade $\mathrm{C}_{\text {atólica }}$

DO RIO DE JANEIRO Of $A \cap$

Ana Luísa Antunes

Hierarquias de poder de instituições na área da Educação

Tese de Doutorado

Tese apresentada como requisito parcial para obtenção do grau de Doutor pelo Programa de Pósgraduação em Educação do Departamento de Educação do Centro de Teologia e Ciências Humanas da PUC-Rio.

Orientadora: Profa ${ }^{a}$ Rosaly Hermengarda Lima Brandão 
Todos os direitos reservados. É proibida a reprodução total ou parcial do trabalho sem autorização do autor, do orientador e da universidade.

\section{Ana Luísa Antunes}

Possui graduação em Pedagogia pelo Instituto Nacional de Educação de Surdos (2009) e mestrado em Educação pela Pontifícia Universidade Católica do Rio de Janeiro (2013). É membro do Comitê de Ética em Pesquisa do Instituto Nacional de Educação de Surdos (CEP-INES) vinculado a Comissão Nacional de Ética em Pesquisa (CONEP/CNS). Possui experiência como docente no ensino superior e na educação básica na rede pública e privada. Foi consultora da Fundação Getúlio Vargas como professora-autora da disciplina de Libras Online. Desde 2014 é professora da educação básica do Instituto Nacional de Educação de Surdos atuando principalmente nos seguintes temas: educação de surdos, educação básica, ética em pesquisa, Bourdieu em Educação, pesquisa de professores, formação de professores e inclusão.

Ficha Catalográfica

\section{Antunes, Ana Luísa}

Hierarquias de poder de instituições na área da educação / Ana Luísa Antunes ; orientadora: Rosaly Hermengarda Lima Brandão. - 2019.

129 f. : il. color. ; $30 \mathrm{~cm}$

Tese (doutorado)-Pontifícia Universidade Católica do Rio de Janeiro, Departamento de Educação, 2019.

Inclui bibliografia

1. Educação - Teses. 2. Campo científico. 3. Pesquisa em educação. 4. Hierarquias institucionais. 5. Bolsa de produtividade. I. Brandão, Zaia. II. Pontifícia Universidade Católica do Rio de Janeiro. Departamento de Educação. III. Título. 


\section{Agradecimentos}

Agradeço à Deus a oportunidade de estar viva, sonhar e poder lutar para realizar cada etapa deste processo.

Agradeço a minha mãe, minha inspiração de vida, que sempre lutou para me proporcionar uma educação de qualidade. Eu sei que você que me ensinou o valor do trabalho, da perseverança e da luta hoje é um anjinho que guia os nossos sonhos lá do alto, juntinho de Deus. Sigo na missão para realizar cada um deles!

Agradeço ao meu esposo, Felipe, que sempre esteve comigo nos momentos mais felizes e mais difíceis desse processo. Nosso amor incondicional é fundamental para eu querer seguir e acreditar.

Agradeço as amigas muito especiais que me incentivaram desde a graduação a buscar minha realização acadêmica e a desejar cada vez mais estar engajada com o que me faz feliz, Graça e Yrlla vocês são muito importantes para mim, vocês me inspiram!

À minha irmã, Fátima, meu cunhado e meus sobrinhos por terem me ajudado a organizar minhas emoções nos momentos em que não sabia lidar com elas trazendo sempre uma lição de amadurecimento e amor.

À minha cunhada, Daniela, e ao Humberto pelo carinho das trocas sobre os desafios da escrita e realização de um doutorado. Nossos diálogos foram sempre muito importantes para mim.

Aos meus sogros pelos lanchinhos, pelo apoio com o cuidado da casa e as orações e palavras de amor que sempre me transmitem serenidade e sentimento de paz.

À minha orientadora, Zaia, que sempre admirei e que me acolheu com muito amor nessa trajetória. A sua orientação com certeza me fez crescer como profissional e ser humano, me ensinando muito e despertando em mim a autoconfiança.

Aos amigos do SOCED, interlocutores desta pesquisa que doaram seu tempo para ajudar em parte da construção do banco de dados que possibilitaram esta tese. Especialmente à minha amiga Priscila agradeço a parceria, os incentivos e a interlocução.

À minha amiga Giselly que me ensina muito mais do que pode imaginar e à minha amiga Luciana, vocês foram fundamentais nessa caminhada!

Ao INES e aos meus amigos de trabalho que sempre foram compreensíveis comigo. Sem eles não conseguiria realizar esta tese.

Aos amigos e colegas de profissão, que nos diálogos contribuíram para que eu me tornasse a profissional e a pessoa que sou. Minha ex-diretora Silvia e minhas amigas Raquel e Ana Claudia obrigada por me incentivarem vôos maiores e por 
acreditarem no meu compromisso com a educação pública. A SME será para sempre um capítulo importante da minha história!

À PUC-Rio e aos funcionários que me auxiliaram nesta trajetória sempre com muita compreensão, ética e carinho. Em especial as secretárias Nancy e Marnie que sempre foram muito pacientes e amigas.

Agradeço a professora Menga Lüdke que sempre me incentivou e encorajou a tentar ser melhor. Obrigada por me oportunizar muitos aprendizados através de sua generosidade de me ceder livros de sua biblioteca, momentos ricos de conversa e até compartilhar alegrias com sua família e amigos dentro e fora do país.

Agradeço aos professores do programa de pós-graduação em Educação pela escuta atenta, pelos conselhos e pela acolhida nos momentos em que mais precisei ao longo desses quase 10 anos freqüentando a PUC como bolsista de apoio técnico, mestranda e doutoranda. Com carinho agradeço a Deus a vida de cada um e o cuidado que vocês têm com as pessoas!

Agradeço a CAPES pela possibilidade de cursar doutorado numa das melhores instituições do país sem custos. Como sou grata! 


\section{Resumo}

Antunes, Ana Luísa; Brandão, Rosaly Hermengarda Lima. Hierarquias de poder de instituições na área da Educação. Rio de Janeiro, 2019. 129p. Tese de Doutorado - Departamento de Educação, Pontifícia Universidade Católica do Rio de Janeiro.

$\mathrm{Na}$ pesquisa tratamos das dinâmicas do campo científico através da acumulação de capitais e da construção das posições de prestígio institucional a partir dos Bolsistas de Produtividade em Pesquisa do CNPq. Produzindo um recorte da pesquisa do SOCED (Grupo de Pesquisas em Sociologia da Educação), coordenado pela pesquisadora Zaia Brandão, sobre a os bolsistas de produtividade do $\mathrm{CNPq}$, nosso objetivo foi compreender a centralidade de algumas instituições na pesquisa em Educação analisando se existem instituições com o poder de "comandar o jogo" no campo cientifico da área. Quais são as instituições que estão hierarquicamente representadas com poder no campo científico na área da Educação a partir da concessão das bolsas de produtividade? Partindo dos agentes (pesquisadores) traçamos uma configuração das instituições prevalentes nessas trajetórias para conhecer o peso relativo das instituições universitárias na luta por hegemonia no campo da Educação. O objeto da investigação são as instituições na composição das hierarquias científico-acadêmicas a partir das trajetórias institucionais e práticas acadêmicas registradas no Currículo Lattes dos pesquisadores bolsista de produtividade das categorias 1 (A, B, C, D) e Sênior. Trabalhamos em nossa pesquisa com dados de todos os PQ-1 (A, B, C e D) com 170 bolsistas que somado aos PQ-Sr (11) compuseram a amostra de 181 pesquisadores. A análise das variáveis do nosso banco de dados dos PQ-1 e PQ-Sr nos permitiu caracterizar, pela instituição de pertença de cada agente, a hierarquia a partir da: instituição e região da instituição de trabalho dos pesquisadores; instituição de doutoramento; relação entre a instituição de formação (doutoramento) e a instituição de pertença; relação entre os tipos de publicações e as posições ocupadas; a relação entre o poder institucional e os periódicos mais atrativos para os pesquisadores bolsistas e; conhecer as instituições responsáveis pelas revistas mais bem avaliadas, com Qualis A1 e A2. As análises evidenciaram a existência de uma política que reproduz a hierarquia de bolsistas e acabam privilegiando instituições que já possuem razoáveis condições de condução de trabalhos científicos. As instituições do topo da hierarquia revelam o poder de "comando do jogo" no campo científico por meio da definição e manutenção das regras e posse de seus próprios periódicos bem qualificados que contribuem para definir o padrão de cientificidade da área. Tais instituições possuem poder que gera uma dinâmica de maior concessão de bolsas para seus pesquisadores e maior financiamento para as pesquisas realizadas pelas suas instituições.

\section{Palavras-chave:}

Campo científico; Pesquisa em Educação; Hierarquias institucionais; Bolsa de produtividade 


\section{Abstract}

Antunes, Ana Luísa; Brandão, Rosaly Hermengarda Lima. Hierarchies of power of institutions in the field of Education. Rio de Janeiro, 2019. 129p. PhD Thesis. Departamento de Educação, Pontifícia Universidade Católica do Rio de Janeiro.

In this research we deal with the dynamics of the scientific field through the accumulation of capital and the construction of positions of institutional prestige from the Research Productivity Grantees of the CNPq. Within the SOCED (Research Group on Educational Sociology) research, coordinated by the researcher Zaia Brandão, on the CNPq productivity fellows, I chose to understand the centrality of some institutions in the research in Education, analyzing if there are institutions with the power of "Command the game" in the scientific field of Education. What are the institutions that are hierarchically represented with power in the scientific field in Education from the granting of productivity grants? From the agents (researchers) we draw a configuration of the institutions prevalent in these trajectories to know the relative weight of the university institutions in the fight for hegemony in the field of Education. The object of the research is the institutions in the composition of the academic-academic hierarchies from the institutional trajectories and academic practices the of researchers registered in the Lattes Curriculum of the productivity grants program of categories 1 (A, B, C, D) and Senior. We worked on the research with data of all the PQ-1 (A, B, C and D) with 170 that added to the PQ-Sr (11) composed the sample of 181 researchers. The analysis of the variables of our database of PQ-1 and PQ-Sr allowed us to characterize, by the institution of each agent, the hierarchy from the: institution and region of the researchers work institution; $\mathrm{PhD}$ degree institution; relationship between the training institution ( $\mathrm{PhD}$ degree) and the work institution; relationship between types of publications and positions in the field; the relationship between institutional power and the most attractive journals for researchers and; know the institutions responsible for the best evaluated journals, with Qualis A1 and A2. The analyzes showed the existence of a policy that reproduces the hierarchy of productivity grants and end up favoring institutions that already have conditions to do scientific work. Institutions at the top of the hierarchy reveal the power of "command of the game" in the scientific field through the definition and maintenance of the rules and they have own wellestablished journals that contribute to defining the scientific standard of the area. Such institutions have power for a greater grant dynamics for their researchers and greater funding for the research maked by their institutions.

\section{Keywords}

Scientific field; Education research; Institutional hierarchies; Productivity grants 


\section{Sumário}

1 Hierarquias de poder de instituições na área da Educação 16

1.1 Apresentando nosso objeto de pesquisa

2 Contextualizando as relações entre os bolsistas de produtividade do CNPq, a Capes e a pós-graduação em Educação no tratamento das hierarquias institucionais na área da Educação.

2.1 A criação da pós-graduação e a Capes (Coordenação de 20 Aperfeiçoamento de Pessoal de Nível Superior)

2.2 As Bolsas de Produtividade do CNPq e nosso objeto de pesquisa 26

2.2.1 As bolsas de produtividade do CNPq 26

2.2.2 Nosso olhar sobre o objeto 29

2.2.3 A construção do recorte da pesquisa: condução do estudo, 31 hipóteses e objetivos

3 Análises: Como está configurada a hierarquia acadêmica?

3.1 A distribuições dos PQs por instituições e regiões do Brasil 33

3.2 A distribuições dos $P Q s$ por regiões do Brasil 36

3.3 Os PQs e suas instituições de doutorado

4 Publicações dos PQs

4.1 Os tipos de publicações dos PQs por níveis dentro da categoria 1 68 de bolsistas de produtividade do CNPq 4.2 Publicações dos PQs em periódicos Qualis A1, A2 e B1 78

4.3 Publicações em periódicos dos PQs por instituições

50 WebQualis e a hierarquia de instituições: quais as relações 98 possíveis?

6 Considerações Finais 
8 Apêndices

8. 1 Apêndice 1- Relação entre nível do bolsista de produtividade e a 124 publicação em periódicos no triênio (2013-2016) por instituição

8.2 Apêndice 2 - Média da idade científica 


\section{Quadros}

Quadro 1 - Número de Programas de Pós-Graduação por região 38

Quadro 2 - Distribuição de bolsas de pós-graduação por estado em 41 todas as áreas

Quadro 3 - Desempenho das principais universidades brasileiras em 43 pesquisa

Quadro 4 - Desempenho em pesquisa por Estado 45

Quadro 5 - Primeiros cursos de doutorado em Educação no Brasil 48

Quadro 6 - Critérios do CA da Educação (2013-2016) 80 


\section{Gráficos}

Gráfico 1 - Volume da produção distribuído nas respectivas Qualis 107 PQs-Sr

Gráfico 2 - Volume da produção distribuído nas respectivas Qualis 108 PQs-1A

Gráfico 3 - Volume da produção distribuído nas respectivas Qualis 113 PQs-1B

Gráfico 4 - Volume da produção distribuído nas respectivas Qualis 114 PQs-1C

Gráfico 5 - Volume da produção distribuído nas respectivas Qualis 115 PQs-1D 


\section{Tabelas}

Tabela 1 - Bolsistas de Produtividade do CNPq do campo da 30 Educação em 2016.

Tabela 2 - Instituição de cada bolsista de produtividade por 35 categoria

Tabela 3 - Distribuição das Instituições com maior concentração 36 de $\mathrm{PQ} / \mathrm{CNPq}$

Tabela 4 - Instituições dos pesquisadores PQ-1A e PQ-Sr da Educação

Tabela 5 - Bolsistas de Produtividade em Pesquisas por regiões do Brasil

Tabela 6 - Instituições no Brasil de doutoramento dos PQ/CNPq

Tabela 7 - Relação entre instituição atual e instituição na qual cursou o doutorado PQ-1A

Tabela 8 - Instituições de doutoramento dos pesquisadores PQ$1 \mathrm{~A}$ e $\mathrm{PQ}-\mathrm{Sr}$

Tabela 9 - Relação entre instituição atual e instituição na qual cursou o doutorado PQ-Sr

Tabela 10 - Relação entre instituição atual e instituição na qual cursou o doutorado PQ-1B

Tabela 11 - Relação entre instituição atual e instituição na qual cursou o doutorado PQ-1C

Tabela 12 - Relação entre instituição atual e instituição na qual cursou o doutorado PQ-1D

Tabela 13 - Média de publicações em anais por níveis no triênio (2013-2016)

Tabela 14 - Média de capítulos de livro por níveis no triênio (2013-2016)

Tabela 15 - Média de livros organizados por níveis no triênio (2013-2016)

Tabela 16 - Média de publicações em periódicos por níveis no triênio (2013-2016) 
Tabela 17 - Volume total de publicações no triênio (2013-2016) 79 de acordo com o tipo de publicação

Tabela 18- Periódicos A1 com maior número de contribuições 82 dos PQs

Tabela 19- Periódicos A2 com maior número de contribuições 84 dos PQs

Tabela 20- Periódicos B1 com maior número de contribuições 86 dos PQs

Tabela 21 - PQs que publicaram menos do que o mínimo de $6 \quad 89$ artigos em periódicos no triênio (2013-2016)

Tabela 22 - Média aproximada do total de publicações em periódicos no triênio (2013-2016) por instituição

Tabela 23 - Média do total de publicações em periódicos por pesquisador durante toda a carreira por instituição

96

Tabela 24 - Total de publicações em periódicos por Região do 98 país com número médio (aproximado) de publicações e idade científica

Tabela 25 - Número de revistas nacionais e internacionais Web Qualis A1 e A2

Tabela 26 - Instituições nacionais responsáveis pelas revistas Qualis A1

Tabela 27 - Instituições nacionais responsáveis pelas revistas 110 Qualis A2 


\section{Siglas e abreviações}

ANPEd - Associação Nacional de Pós-Graduação em Educação

$\mathrm{CA}(\mathrm{s})$ - Comitê de Assessoramento

CA-Ed - Comitê de Assessoramento da área da Educação

CAPES - Coordenação de Aperfeiçoamento de Pessoal de Nível Superior CE- Centro- Oeste

CNPq - Conselho Nacional de Desenvolvimento Científico e Tecnológico

FCC- Fundação Carlo Chagas

FGV - Fundação Getúlio Vargas

FGV- Fundação Getúlio Vargas

FIOCRUZ - Fundação Oswaldo Cruz

FURG - Universidade Federal do Rio Grande

IBGE - Instituto Brasileiro de Geografia e Estatística

IES - Instituições de Ensino Superior

IESAE - Instituto de Estudos Avançados em Educação

INEP - Instituto Nacional de Estudos e Pesquisas Educacionais Anísio

Teixeira

$\mathrm{N}$ - Norte

NE- Nordeste

NUPES - Núcleo de Pesquisas sobre o Ensino Superior

PG - Pós-graduação

PNPG(s) - Plano Nacional de Pós-Graduação

PQ- Sr - Bolsista de Produtividade em Pesquisa 1 -Sênior

$P Q(s)$ - Bolsista de produtividade

PQ1A - Bolsista de Produtividade em Pesquisa 1-A

PQ1B - Bolsista de Produtividade em Pesquisa 1-B

PQ1C - Bolsista de Produtividade em Pesquisa 1-C

PQ1D - Bolsista de Produtividade em Pesquisa 1-D

PQ2 - Bolsista de Produtividade em Pesquisa

PUC/RS - Pontifícia Universidade Católica do Rio Grande do Sul

PUC/SP - Pontifícia Universidade Católica de São Paulo

PUC-Campinas - Pontifícia Universidade Católica de Campinas 
PUC-Goiás - Pontifícia Universidade Católica de Goiás

PUC-Rio - Pontifícia Universidade Católica do Rio de Janeiro

S- Sul

SBC - Sociedade Brasileira de Cardiologia

SE- Sudeste

SOCED- Grupo de Pesquisa em Sociologia da Educação

UECE - Universidade Estadual do Ceará

UEL - Universidade Estadual de Londrina

UEM - Universidade Estadual de Maringá

UEPG - Universidade Estadual de Ponta Grossa

UEPG - Universidade Estadual de Ponta Grossa

UERJ - Universidade do Estado do Rio de Janeiro

UFAL - Universidade Federal de Alagoas

UFBA - Universidade Federal da Bahia

UFC - Universidade Federal do Ceará

UFES - Universidade Federal do Espírito Santo

UFF - Universidade Federal Fluminense

UFJF - Universidade Federal de Juiz de Fora

UFMA - Universidade Federal do Maranhão

UFMG - Universidade Federal de Minas Gerais

UFMT - Universidade Federal de Mato Grosso

UFPA - Universidade Federal do Pará

UFPB - Universidade Federal da Paraíba

UFPE - Universidade Federal de Pernambuco

UFPEL - Universidade Federal de Pelotas

UFPR - Universidade Federal do Paraná

UFRGS - Universidade Federal do Rio Grande do Sul

UFRJ - Universidade Federal do Rio de Janeiro

UFRN - Universidade Federal do Rio Grande do Norte

UFSC - Universidade Federal de Santa Catarina

UFSCAR - Universidade Federal de São Carlos

UFSM - Universidade Federal de Santa Maria

UFU - Universidade Federal de Uberlândia

UFV - Universidade Federal de Viçosa 
UnB - Universidade de Brasília

UNEB - Universidade do Estado da Bahia

UNESP - Universidade Estadual Paulista

Unicamp - Universidade Estadual de Campinas

UNIEVANGÉLICA - Centro Universitário de Anápolis

UNIFESP - Universidade Federal de São Paulo

UNINOVE - Universidade Nove de Julho

UNISINOS - Universidade do Vale do Rio dos Sinos

UNISO - Universidade de Sorocaba

USP - Universidade de São Paulo

UTP/PR - Universidade Tuiuti do Paraná 


\title{
Hierarquias de poder de instituições na área da Educação
}

\begin{abstract}
O universo "puro" da mais "pura" ciência é um campo social como outro qualquer.(...)enquanto sistema de relações objetivas entre posições adquiridas (em lutas anteriores), é o lugar, o espaço de jogo de uma luta concorrencial. $O$ que está em jogo especificamente nesta luta é o monopólio da autoridade científica definida, de maneira inseparável, como capacidade técnica e poder social. (BOURDIEU, 1983 p.123)
\end{abstract}

\section{1}

\section{Apresentando nosso objeto de pesquisa}

A sociologia construtivista de Pierre Bourdieu mobiliza grande interesse da comunidade científica pelas propriedades dos conceitos que nos permitem integrar dimensões subjetivas e interativas na análise das estruturas sociais.

A obra de Bourdieu nos cerca de conceitos para compreender a dinâmica entre sociedade e agentes. Conjugando objetividade e subjetividade o autor desenvolveu a noção de um ethos construído entre os agentes que partilham de um mesmo campo. Campo este que, enquanto um microcosmo dotado de regras específicas construídas pelos agentes e suas respectivas posições, mobiliza a utilização (e em alguns casos de reestruturação) do habitus nas relações de disputas por posições (nem sempre conscientes) através da estrutura de capitais (econômico, social, cultural, linguístico, científico, simbólico) acumulados que produzem ou mesmo reproduzem estratégias de conservação ou transformação das regras do jogo.

A partir desses conceitos, para compreender o campo científico, elaboramos um estudo exploratório com os bolsistas de produtividade em Educação 1A (PQ1A) e Sênior (PQ-Sr) do CNPq (Conselho Nacional de Desenvolvimento Científico e Tecnológico) que serviu de base para a formulação do problema proposto neste projeto: compreender as hierarquias institucionais na área, 
analisando se existem instituições com o poder de "comandar o jogo" no campo científico da Educação ${ }^{1}$.

O estudo exploratório desenvolvido em uma disciplina de pós-graduação Leituras de Pierre Bourdieu, com o debate coletivo da obra Os usos sociais da ciência - por uma sociologia clínica do campo científico (BOURDIEU, 2004) fundamentou a produção de um banco de dados sobre os bolsistas de produtividade do CNPq a partir de informações registradas no Currículo Lattes $^{2}$ para visualizarmos as instituições e posições dos pesquisadores no campo da Educação.

Os dados empíricos produzidos sobre a posição das instituições dos bolsistas de produtividade suscitaram hipóteses, sobre processos de capitalização de forças internas e externas ao campo universitário, para caracterizar as estratégias e estruturas de capitais que garantem (ou garantiram) as posições de destaque no campo científico da pesquisa em Educação (COCK, et al., 2018).

Considerando a necessidade da ampliação das variáveis que correspondem ao "quadro dos caracteres pertinentes de um conjunto de agentes ou de instituições" sugerido na página 29 do livro "O poder simbólico" (BOURDIEU, 1989), o banco de dados do estudo exploratório (PQ-1A e Sênior) foi expandido incorporando todos os pesquisadores das categorias 1B, 1C e 1D, a fim de obtermos um panorama da distribuição do capital científico na área da pesquisa em Educação, no ano de $2016^{3}$.

\footnotetext{
${ }^{1}$ Em nossa pesquisa nosso objeto de análise serão as instituições. Portanto, não mencionaremos o nome dos pesquisadores bolsistas de produtividade (PQs).

${ }^{2} \mathrm{O}$ Currículo Lattes é um currículo elaborado nos padrões da Plataforma Lattes, gerida pelo $\mathrm{CNPq}$ (Conselho Nacional de Desenvolvimento Científico e Tecnológico). A Plataforma Lattes é resultado da experiência do $\mathrm{CNPq}$ na integração de bases de dados de Currículos, de grupos de pesquisa e de instituições em um único sistema de informação. O Currículo Lattes se tornou um padrão nacional no registro do percurso acadêmico de estudantes e pesquisadores do Brasil. Atualmente é adotado pela maioria das instituições de fomento, universidades e institutos de pesquisa do país. A riqueza de informações, a abrangência e confiabilidade são elementos indispensáveis aos pleitos de financiamentos na área de ciência e tecnologia. O Currículo Lattes é mais abrangente que o Curriculum Vitae. Ele é mais longo, pois deve mencionar detalhadamente tudo o que está relacionado com a carreira do profissional. Todos os dados da Plataforma Lattes estão disponíveis ao público para consulta na internet. Para saber mais acesse: http://lattes.cnpq.br/.

3 A bolsa de produtividade provê uma complementação salarial de acordo com o nível do pesquisador (2, 1D, 1C, 1B, 1A e Sênior). Para receber a bolsa que possui duração de 3 a 4 anos, o pesquisador deve submeter um pedido periodicamente. Para saber maiores detalhes consultar o Regimento da Bolsa de Produtividade disponível em: http://www.cnpq.br/documents/10157/5f43cefd-7a9a-4030-945e-4a0fa10a169a. Acesso em $24 / 09 / 2016$.
} 
A leitura do campo se dará através da distribuição de propriedades entre os indivíduos (BOURDIEU, 1989 p.29). Portanto, incluímos no banco de dados informações referentes à formação acadêmica (graduação e pós-graduação) - ano das titulações, orientador e instituições - , área de atuação (linhas de pesquisa), instituição de atuação, data de ingresso na instituição de atuação, orientações de doutorado, indicadores bibliométricos da produção científica e vinculação a comitês científicos ${ }^{4}$.

Um primeiro levantamento bibliográfico sobre o recorte de nossa pesquisa, evidenciou a carência de investigações sobre os bolsistas de produtividade em pesquisa do $\mathrm{CNPq}$ na área da Educação. Encontramos alguns trabalhos sobre a Grande Área das Humanidades e Ciências Sociais Aplicadas com enfoque bibliométrico (WAINER e VIEIRA, 2013); tratando da área da Sociologia (VICTOR, 2014); sobre bolsistas de produtividade da Psicologia (SACCO et al., 2016); e sobre os pesquisadores bolsistas na perspectiva de gênero abordando todas as áreas das Ciências Humanas (GUEDES, AZEVEDO e FERREIRA, 2015) que indicavam a forte seletividade do sistema de seleção e bonificação.

Especificamente sobre a área da Educação encontramos alguns estudos recentes com questões que tentam desvendar as subjetividades no processo de seleção dos bolsistas de produtividade sendo, uma investigação sobre o perfil de formação e trajetória dos pesquisadores atuantes no ensino de ciências e matemática (SILVA, 2011); outro que analisou através das trajetórias e publicações dos bolsistas de produtividade a relação entre produção, comunicação e distinção científica revelando a grande subjetividade dos critérios de avaliação utilizados pelo CNPq para manutenção e concessão das bolsas (NASCIMENTO, 2016); e um recente estudo descritivo com enfoque sobre gênero, regiões do país e projetos dos bolsistas de produtividade na área da Educação (LEITE e NETO, 2017).

“Os conceitos ou noções são caracterizados não por definições estáticas, mas pelos seus usos e interligações no processo de pesquisa, sendo o ato científico a construção do objeto" (BOURDIEU, PASSERON e CHAMBOREDON, 1968 apud CATANI, 2011 p.191). Portanto, atentando-nos para a necessidade de

\footnotetext{
${ }^{4} \mathrm{O}$ banco de dados possui diversas variáveis considerando as utilizações do SOCED. No entanto, esclareço que não trabalharemos com todos os dados disponíveis nesta pesquisa em virtude do objeto de pesquisa e pela ausência do registro de algumas informações dos PQs no currículo Lattes como, por exemplo, a ausência de informação sobre a participação em comitês de $23 \mathrm{PQs}$.
} 
"prevenção contra o fetichismo dos conceitos e da "teoria",, realizaremos um estudo que, ao invés de considerar os instrumentos "teóricos" (os conceitos de habitus, campo, capital, etc..) em si mesmo, irá colocá-los em ação para a compreensão das hierarquias no campo da Educação.

Para fins de análise trabalharemos com as instituições mais recorrentes entre os bolsistas de produtividade da área da Educação mesmo sabendo que tal campo é, de fato, um microcosmo conectado às estruturas do conjunto do mundo social e seus conflitos.

Operando com alguns conceitos de Pierre Bourdieu, nosso objetivo é compreender a centralidade de algumas instituições na pesquisa em Educação. Quais são as instituições que estão hierarquicamente representadas com poder no campo científico na área da Educação a partir da concessão das bolsas de produtividade?

O campo científico da Educação, não diferente de outros campos, também possui um campo do poder, lugar de relações de força entre as posições sociais ocupadas na luta pela distinção e legitimidade. Trata-se de jogos de poder onde os capitais simbólicos podem constituir distinção de fundamental importância para dominar as regras do jogo e construir vantagens. 
Contextualizando as relações entre os bolsistas de produtividade do $\mathrm{CNPq}$, a Capes e a pós-graduação em Educação no tratamento das hierarquias institucionais na área da Educação

\section{1}

\section{A criação da pós-graduação e a Capes (Coordenação de Aperfeiçoamento de Pessoal de Nível Superior)}

Nossa opção por fazer esta breve abordagem sobre a criação da pósgraduação em Educação está relacionada ao reconhecimento do protagonismo de algumas instituições no processo de criação da pós-graduação e nos movimentos para a organização e institucionalização da política científica no Brasil (HENRIQUES, 1998; GATTI，1983; SAVIANI，2000; FERRARO，2005; CAMPOS e FÁVERO, 1994; MENDONÇA, 1999).

As relações tecidas com a criação da pós-graduação ao longo da pesquisa ${ }^{5}$ ajudam a mostrar as instituições do campo do poder na área, tanto pelo pioneirismo, enquanto universidade/instituição de ensino superior, quanto pela notoriedade diante da presença e produtividade de seus agentes.

As pesquisas em Educação no Brasil começam a ser desenvolvidas a partir da década de 1930 com a criação do Instituto Nacional de Estudos e Pesquisas Educacionais Anísio Teixeira (INEP). Nos anos de 1950, a criação do Centro Brasileiro de Pesquisas Educacionais (CBPE) e os Centros Regionais (São Paulo, Minhas Gerais , Rio Grande do Sul, Pernanbuco e Bahia) também contribuiram para a pesquisa em Educação e o fortalecimento de um espaço específico de produção, formação e estímulo em diversas regiões do país (GATTI, 2001). No entanto, foi com a implementação da pós-graduação que se acelerou o desenvolvimento da área de pesquisa em Educação (SANTOS e AZEVEDO, 2009).

Considerando a criação do INEP (Instituto Nacional de Estudos Pedagógicos), em 1938, marco inicial da trajetória da pesquisa em Educação,

\footnotetext{
${ }^{5}$ Objetivando operar com conceitos e dar ênfase a nossa empiria, optamos por não nos alongarmos em ensaios teóricos sobre a teoria de Bourdieu e nem sobre a história da pós-graduação. Nos propusemos a tecer a teoria em diálogo com a empiria destacando neste item apenas a uma breve contextualização e diálogo com fontes bibliográficas para o aprofundamento do leitor.
} 
Aparecida Joly Gouveia (1971 apud FERRARO, 2005 p.3 e 4 ) examinando as pesquisas em educação até 1970 caracteriza três momentos: um primeiro momento no qual os estudos voltam-se para os aspectos psicopedagógicos; um segundo momento (1956-1964)no qual a criação do CBPE , em 1956, e os Centros Regionais de Pesquisa localizados em diferentes estados do país instigam preocupações de cunho sociológico a partir da incumbência de elaborar pesquisas que subsidiassem uma política educacional para o país e; um terceiro momento (nos primeiros anos da Ditadura Militar) no qual predominam os estudos de natureza econômica (FERRARO, 2005).

A criação da pós-graduação no Brasil se deu no contexto do governo militar mobilizado por uma política desenvolvimentista a partir do Parecer $n^{\circ} 977$ CES/CFE, de 3 de dezembro de 1965, conhecido como Parecer Newton Sucupira, e da Reforma Universitária de 1968, quando educação e desenvolvimento econômico estavam atrelados ao projeto de governo. (SAVIANI, 2008; ALVES e OLIVEIRA, 2014)

No âmbito do aparelho estatal federal em um contexto histórico marcado pelo modelo nacional-desenvolvimentista, a Capes (Coordenação de Aperfeiçoamento de Pessoal de Nível Superior $)^{6}$ tem papel central na elaboração de políticas públicas educacionais no seio do Ministério da Educação. Tal centralidade teve como resultados a construção de um sistema nacional de pósgraduação com parâmetros avaliativos previstos pela entidade.

A legislação nacional estipulava que os programas de pós-graduação deveriam seguir o modelo americano, composto de uma combinação de curso, créditos, exames e uma tese e dissertação supervisionadas. Esta legislação dividiu a pósgraduação em duas categorias, "stricto sensu", voltada para carreira acadêmica, e "lato sensu", para quem trabalha em outras organizações ou outras atividades profissionais, e estabelece as categorias de mestrado e de doutorado, sem que, na época, a primeira seja obrigatoriamente um requisito para a segunda. (MORITZ et al. 2011, p.6)

Com forte influência do modelo americano, reconhecia-se que o governo federal deveria assumir a política de pós-graduação, uma vez que as universidades

\footnotetext{
${ }^{6}$ A Capes foi instituída como Campanha em 1951, mas só foram desencadeadas suas ações dez anos depois, em 1961. A instituição vinculada ao governo federal começou na década de 1970 a participar de uma série de experiências avaliativas dos cursos de mestrado e doutorado existentes no país. Hoje, as atividades da Capes são desenvolvidas através de quatro (04) grandes linhas de ação: o avaliação da pós-graduação "stricto sensu"; o acesso e divulgação da produção científica; o investimentos na formação de recursos de alto nível no país e exterior e; o promoção da cooperação científica nacional e internacional. A Capes, dentro do seu campo de atuação, estabeleceu um padrão para os programas de pós-graduação que muito contribuem para o desenvolvimento e crescimento científico no país. (MORITZ et al. 2011)
} 
não teriam condições para isso. No documento Rumo à Reformulação Estrutural da Universidade Brasileira, editado pelo MEC em 1966 (incorporando trechos do relatório Atcon ${ }^{7}$ (1966)) que indicava a necessidade e dava a Capes a incumbência de criar, em cada universidade, um fundo de aperfeiçoamento aos seus respectivos docentes, assim como a criação de um fundo destinado ao aperfeiçoamento ou formação adicional de professores que ainda não pertenciam aos quadros efetivos de uma universidade (FÁVERO, 2006).

A reforma impulsionou a articulação entre ensino e pesquisa que deveriam compor a organização de toda a universidade. Havia um movimento articulado do estado brasileiro em direção à pós-graduação: normatização, acompanhamento, avaliação, fomento, mas também um planejamento das ações para sua manutenção e expansão.

Até então, o processo de expansão da pós-graduação havia sido "parcialmente espontâneo", mas pressionado por motivos conjunturais e uma retórica desenvolvimentista, os sucessivos governos militares estabeleceram medidas para garantir seu desenvolvimento sistemático dando origem ao Conselho Nacional de Pós-Graduação, em 1974. Este conselho tinha como objetivo formular políticas de implementação e funcionamento da pós-graduação, assim como o I Plano Nacional de Pós-Graduação $(\mathrm{PNPG})^{8}$ para o período de 1975-1977 (SANTOS e AZEVEDO, 2009).

O modelo americano serviu como referência para a implantação da pós-graduação no Brasil, mas a influência européia também foi decisiva, uma vez que a experiência de pós-graduação brasileira resultou, pois, dessa dupla influência: "o modelo organizacional americano que foi articulado, no funcionamento efetivo do processo formativo, com o modelo europeu pautado pela exigência do trabalho teórico autonomamente conduzido. Daí termos chegado a um modelo brasileiro de pós-graduação, sem dúvida bem mais rico do que aqueles que lhe deram origem, pois promoveu a fusão entre uma estrutura organizacional bastante articulada, derivada da influência americana, e o empenho em garantir um grau satisfatório de densidade teórica, decorrente da influência européia." (SAVIANI, 2008 p.310)

\footnotetext{
${ }^{7}$ O Relatório é resultante das visitas de Rudolph P. Atcon às universidades brasileiras em 1968, quando buscava dados para o seu diagnóstico. Atcon foi uma figura bem conhecida no Brasil no período de 1965-1968, prestando serviços ao governo brasileiro. Depois do golpe de 1964, a partir do acordo assinado entre o MEC e a Usaid, em maio de 1965, Atcon foi contratado pela Diretoria do Ensino Superior para "propor as alterações estruturais que julgasse necessárias para as universidades brasileiras" (CUNHA, 2007, p. 188).

${ }^{8}$ Os Planos Nacional de PósGraduação (PNPG), embasados pelas avaliações feitas pela Capes, sintetiza as diretrizes que norteiam as políticas públicas de qualificação de pessoal em nível de mestrado e doutorado. O Plano faz periódicamente um diagnóstico da pós-graduação nacional. A partir dos levantamentos da avaliação da Capes são apresentadas propostas de diretrizes, cenários de crescimento do sistema, metas e orçamento para a execução das ações.
} 
Em 1970 são instituídos os Centros Regionais de Pós-Graduação e a estrutura da Capes é alterada passando a ser órgão central superior, gozando de autonomia administrativa e financeira com poder decisório sobre a política nacional de pós-graduação. Segundo Gatti (1983) entre os anos de 1971/72 forma criados 10 cursos de pós-graduação no país contando com professores qualificados no exterior. Os primeiros programas foram os da PUC-Rio (1965) com 65 alunos e da PUC/SP (1969) com 171 alunos. E em 1975 já eram 16 programas de mestrado funcionando no país.

Os primeiros cursos de doutorado no país começaram a surgir em 1975 na Unicamp e em 1976 na PUC-Rio9. Em 1976, em pleno movimento de qualificação dos professores e implantação da pós-graduação, surge o primeiro processo de avaliação dos Programas de Pós-Graduação pela Capes (em 1976). Neste ano também é instituído pela Capes o PICD (Programa Institucional de Capacitação de Docentes) concedendo bolsas de estudo para professores universitários buscarem titulação nos programas de mestrado e doutorado nos principais centros de pós-graduação do país.

A pós-graduação em nosso país chegou como uma política de Estado contando com a participação/engajamento dos docentes pesquisadores e das entidades científicas das diferentes áreas do campo científico-universitário. (ALVES e OLIVEIRA, 2014)

Gatti (1983) em artigo no qual faz um balanço ainda precoce da pósgraduação, entre 1978 e 1981, ressalta a existência de programas de mestrado em todas as regiões do país, mas destaca maior número de alunos nos programas da região Sudeste e maior número de professores doutores na região Sul. A autora aborda a rentabilidade dos diplomas das regiões Sul e Sudeste seja pela proximidade geográfica, seja pela maior facilidade de conseguir financiamento para estudar em universidades dessas regiões. Ela demonstra preocupação com a ampliação dos programas de pós-graduação nos diferentes Estados como "possibilidade de ampliação das possibilidades de formação pessoal e criação de condições para uma produção científica mais diversificada para discussões mais variadas e menos condicionadas a um ou dois centros aglutinadores" (GATTI, 1983 p.6).

\footnotetext{
${ }^{9}$ Ver dados em Gatti (1983).
} 
O primeiro PNPG, em seu diagnóstico e prospecção para a pós-graduação, já definia como uma das principais necessidades: institucionalizar o sistema nacional de pós-graduação como atividade regular das universidades contando com financiamento estável; elevação dos padrões de desempenho e racionalização da utilização de recursos e; planejamento da expansão do Sistema Nacional de Pós-Graduação para equilibrar a oferta nas diferentes regiões evitando disparidades (FRANÇA, 2014). Para a execução dessas metas foram disponibilizados programas de concessão de bolsas para alunos de tempo integral, para expansão da capacitação docente (PICD) além de um programa de admissão docente nas universidades para a pós-graduação.

Saltando alguns episódios da história da pós-graduação que vão de documentos à melhor estruturação de entidades e associações da área, muito bem analisada por trabalhos como o de França (2014); Campos e Fávero (1994); Saviani (2001); Cury (2005) entre outros já aqui mencionados, consideramos que a constituição do sistema de pós-graduação para o ensino stricto sensu e para a pesquisa produziu um grupo docente bem qualificado.

Ao longo das últimas décadas esse grupo criou mecanismos de seleção/avaliação bastante exigentes e fortemente modelados pelas agências de avaliação e fomento, especialmente Capes e CNPq, tanto para ingresso e avaliação da pós-graduação quanto para manutenção de posições privilegiadas no campo do poder da área e na aquisição de recursos/financiamentos.

Sendo uma das grandes financiadoras e reguladoras da pós-graduação desde sua origem no país, a Capes desfruta de legitimidade junto à comunidade científica. A avaliação elaborada pelos pares da área, no entanto, diante da acirrada concorrência, entre o grande volume de programas (atualmente 178), tem intensificado o trabalho docente e a produtividade intelectual tendo em vista a necessária performance produtiva para conquistas de posições de reconhecimento como as bolsas de produtividade em pesquisa, financiamentos e boa avaliação de seus respectivos programas de pertença.

A autoridade científica é, portanto, um misto de competência técnica e reconhecimento dos pares mediado pelas instâncias oficiais federais $(\mathrm{CNPq}$ e 
Capes), estaduais (as Fundações Estaduais de Pesquisa) e demais entidades financiadoras de pesquisas científicas ${ }^{10}$.

A marca mais profunda da pós-graduação brasileira no contexto atual talvez seja sua profunda vinculação e dependência do Estado, sobretudo por meio do fomento articulado à avaliação dos cursos/programas. Alves e Oliveira (2014) ressaltam os aspectos negativos da competição no campo da pós-graduação destacando a dificuldade de gestão dos cursos/programas que se dedicam permanentemente a atender às exigências avaliativas da Capes.

"O Estado, enquanto espaço de relações de força e de sentido é produtor de princípios de classificação suscetíveis de serem aplicados ao mundo social (...)

é dotado de um trunfo formidável: fazer crer naquilo que dizem". (BOURDIEU, 2014, p.24, negrito nossos).

De fato, a participação de algumas instituições no surgimento da pósgraduação conforme teceremos ao longo de nossa análise e o poder de alguns pesquisadores ao ajudarem a definir as regras do jogo podem constituir diferencial para o alcance de fomento e posições destacadas revelando o poder de instituições.

Bourdieu (1989) revela que uma das dificuldades para compreendermos os espaços sociais é a impossibilidade de apreendermos de outra forma que não através da distribuição de propriedades entre os indivíduos devido às informações acessíveis estarem sempre associadas a estes agentes.

Assim, esta pesquisa visa pensar as dinâmicas do campo científico através da acumulação de capitais e da construção das posições de prestígio institucional a partir das informações que temos sobre os agentes (Bolsistas de Produtividade em Pesquisa do CNPq) de acordo com nosso banco de dados, em especial sobre os dados de formação, produção e pertença institucional.

Entendemos que tratar de instituições universitárias não se constitui propriamente um campo. Concordamos com Cunha (2006) ao afirmar que elas participariam de pelo menos quatro campos: o campo educacional, o profissional, o cultural e o da pesquisa. Todos esses campos funcionam numa cadeia de interdependência. Mas para fins de análise, na nossa pesquisa nos interessa entender as estratégias posicionais para manter-se em posição privilegiada na

\footnotetext{
${ }^{10}$ Para conhecer mais sobre agências de fomento e centros independentes de pesquisa, ver Campos e Fávero (1994).
} 
hierarquia da área da Educação através das instituições mais recorrentes entre os bolsistas de produtividade sabendo que tal campo é, de fato, um microcosmo ${ }^{11}$ conectado às estruturas do conjunto do mundo social e seus conflitos.

Portanto, a seguir, caracterizaremos as bolsas de produtividade, um dos incentivos dado pelo $\mathrm{CNPq}$ aos pesquisadores que se destacam em nosso país apresentando mais detidamente como trataremos nossos dados na pesquisa.

\section{2}

\section{As Bolsas de Produtividade do CNPq e nosso objeto de pesquisa}

\subsection{1}

\section{As bolsas de produtividade do $\mathrm{CNPq}$}

A noção de que "antiguidade é posto" ainda se aplica à hegemonia dos cientistas das ciências exatas na direção das principais agências estatais responsáveis pelas definições de políticas públicas no campo da pesquisa. É longa a história das lutas das ciências humanas e sociais pelo reconhecimento das especificidades de suas práticas científicas.

Criado em 1951 com o nome Conselho Nacional de Pesquisa, o CNPq representou um esforço de estabelecer no país uma política nuclear, posteriormente abandonada por falta de viabilidade política e econômica. O CNPq foi retomado em 1975 conjugando-se a estrutura burocratizada de planejamento como uma entidade jurídica de direito privado, sob a forma de fundação vinculado à SEPLAN (Secretaria de Planejamento) com o nome de Conselho Nacional de Desenvolvimento Científico e Tecnológico. Atualmente o $\mathrm{CNPq}$, enquanto agência do Ministério da Ciência, Tecnologia e Inovação (MCTI), tem como principais atribuições fomentar a pesquisa científica e tecnológica e incentivar a formação de pesquisadores brasileiros.

A criação do CNPq na estrutura do Ministério de Ciência e Tecnologia e da Capes $^{12}$ ligada ao Ministério da Educação conferiu um importante impulso na

\footnotetext{
11 Bourdieu começou elaborara a noção de campo no inicio dos anos 1960 e para ele são um "conjunto de microcosmos sociais dotados de autonomia relativa, com lógicas e possibilidades próprias, específicas, com interesses e disputas irredutíveis ao funcionamento de outros campos". (CATANI, 2011, p.192)

12 A Capes (Coordenação de Aperfeiçoamento de Pessoal de Nível Superior) é uma fundação vinculada ao Ministério da Educação do Brasil que atua na avaliação, expansão e consolidação da pós-graduação stricto sensu em todos os estados do país.
} 
regulamentação e apoio financeiro aos programas de pós-graduação e às atividades de pesquisa nas universidades.

Disponibilizada desde 1976, a bolsa de produtividade adquiriu maior atratividade no meio acadêmico a partir da década de 1990 quando aumentou o dispêndio público em atividades de ciência e tecnologia (C\&T). Se antes as bolsas oferecidas pela agência de fomento já constituíam

um instrumento de diferenciação simbólica entre pares, na atualidade se institucionalizou como um sistema hierarquizado de posições, tipificando um perfil de excelência do que pode ser considerado uma elite científica - a de especialistas e profissionais da pesquisa, a quem se reconhece a liderança na condução das atividades de C\&T no país e se contempla com recursos materiais e simbólicos que lhes são exclusivos. (GUEDES et al.2015 p.369).

Dentre os diversos incentivos do CNPq está a bolsa de produtividade que é organizada nos seguintes níveis: 2, 1D, 1C, 1B, 1A e Sênior. Ela é concedida aos pesquisadores que se destacam entre os seus pares, valorizando a produção científica dos mesmos segundo critérios normativos e específicos, análise comparativa de mérito e classificação das propostas por Comitês de Assessoramento $^{13}$ (CAs) específicos do CNPq de acordo com o regimento de cada área $^{14}$. O desempenho do pesquisador é acompanhado pelo $\mathrm{CNPq}$ mediante análise de relatórios ou outras formas de acompanhamento definidas de acordo com as especificidades da modalidade ${ }^{15}$.

Para estar inserido na categoria 1 (objeto de nosso estudo), distribuída nos níveis $\mathrm{A}, \mathrm{B}, \mathrm{C}$ e $\mathrm{D}$, é necessário que o pesquisador tenham no mínimo 8 anos de doutorado no momento de implementação da bolsa. Para manter-se na categoria 1, a mais alta, o pesquisador é enquadrado nos quatro diferentes níveis com base comparativa entre os seus pares e nos dados dos últimos 10 (dez) anos devendo no todo privilegiar a qualidade e o conjunto da obra do pesquisador que demonstre capacidade de formação contínua de recursos humanos.

\footnotetext{
${ }^{13}$ Os CAs estão organizados por subáreas do conhecimento. Eles são compostos por pesquisadores reconhecidos da subárea, indicados por um conselho deliberativo do CNPq, que seleciona os membros através de consultas às entidades científicas, à comunidade científica, entre outros. Os critérios de julgamento específicos do CA de Educação (COSAE/ED) estão disponíveis em http://cnpq.br/web/guest/view/-/journal_content/56_INSTANCE_0oED/10157/5966303. Acesso em 12/02/2017.

14 Regimento da bolsa de produtividade disponível em : http://www.cnpq.br/documents/10157/5f43cefd-7a9a-4030-945e-4a0fa10a169a. Acesso em $24 / 09 / 2016$

${ }^{15}$ Mais informações e detalhes sobre esses critérios, conferir o Anexo III da Resolução Normativa $\mathrm{RN}-028 / 2015$, disponível em:<http://cnpq.br/view//journal_content/56_INSTANCE_0oED/10157/>. Acesso em 24/09/2016.
} 
Há regras específicas para cada nível. No entanto, todos pesquisadores da categoria 1 devem estar vinculados a grupos de pesquisa inscritos no Diretório de Pesquisa do CNPq; apresentar projeto com relevância científica para a área; apresentar regularidade na produção científica e ter publicações em periódicos científicos classificados como A1, A2 e B1 no Qualis; orientar com regularidade dissertações e teses de doutorado; participar da gestão acadêmico-científica em órgãos internos e/ou externos à instituição à qual está vinculado; coordenar projetos nucleadores de diferentes grupos de pesquisa no país; além de ter inserção acadêmica internacional ${ }^{16}$.

Sênior é uma distinção concedida aos pesquisadores que, situados no topo da hierarquia, comprovam posse anterior de bolsa de produtividade na categoria 1 nos níveis A e B por, no mínimo 15 anos, consecutivos ou não.

Ser bolsista de produtividade do CNPq, seja em qualquer nível, já confere diferencial no meio acadêmico em se tratando da acumulação de capital científico. Os níveis representam a gradação hierárquica no campo, uma forma de capital simbólico (distinção no campo).

A bolsa de produtividade em pesquisa não é distribuída apenas baseandose na qualidade de um projeto submetido, mas principalmente na "qualidade do pesquisador", definida por uma distinção entre categorias "de natureza quantiqualitativa" de acordo com os perfis estabelecidos pelo Comitê Assessor (CA) da área de Educação e a disponibilidade de recursos existentes na área.

Ao analisar as trajetórias acadêmicas, no que concerne a produção científica dos bolsistas de produtividade (PQ 1, PQ 2, PQ-Sr) do $\mathrm{CNPq}$ da área da Educação, entre 1990 a 2015, Nascimento (2016 p.106) denuncia os critérios de avaliação/concessão de bolsas enquanto "enunciados vazios de sentido objetivo, mas repleto de subjetividade relativizada". Ainda sobre os critérios de concessões das bolsas de produtividade a pesquisadora afirma que são palavras e enunciados "carregados de subjetividades interpretativas que não refletem o que, de fato, distingue um PQ 1A de outro PQ 2" (NASCIMENTO, 2016 p.109)

\footnotetext{
${ }^{16}$ Para maiores detalhes sobre critérios do CA da área da educação para cada nível dos bolsistas de produtividade da categoria 1 e sobre categoria 2, consultar: http://cnpq.br/web/guest/view//journal_content/56_INSTANCE_0oED/10157/5966303. Acesso em: 03/10/2017.
} 
Para a construção de nossa empiria levantamos no CNPq o número total de pesquisadores por categoria e nível que pertencem à modalidade Bolsa de Produtividade (PQ) para a área de Educação em 2016 (Tabela 1).

Tabela 1 - Bolsistas de Produtividade do CNPq do campo da Educação em 2016.

\begin{tabular}{|l|c|c|}
\hline \multicolumn{2}{|c|}{ CATEGORIAS } & $N^{\circ}$ DE BOLSISTAS \\
\hline \multirow{2}{*}{ Sênior } & $11(2,8 \%)$ \\
\hline \multirow{3}{*}{} & A & $30(7,6 \%)$ \\
\cline { 2 - 3 } & B & $25(6,3 \%)$ \\
\cline { 2 - 3 } & C & $34(8,6 \%)$ \\
\cline { 2 - 3 } 2 & D & $81(20,5 \%)$ \\
\hline \multicolumn{2}{|c|}{ Total } & $214(54,2 \%)$ \\
\hline
\end{tabular}

Fonte: banco de dados SOCED / Plataforma Lattes - CNPq, 2016.

Trabalhamos inicialmente em nossa pesquisa com dados de 41 bolsistas $^{17}$, sendo 11 PQ-Sr e 30 bolsistas PQ-1A dentro de um universo de 395 bolsistas e, em seguida, ampliamos a nossa análise para todos os PQ-1 (A, B, C e D) com 170 bolsistas que, somado aos PQ-Sr (11), compuseram a amostra de 181 pesquisadores.

Levando-se em conta que os bolsistas de produtividade formam um grupo de elite em nível nacional, os 181 PQs que analisamos aqui representam a elite dentro desta elite, um grupo que tem não só um acúmulo de capital acadêmico, mas também de capital simbólico, o qual aufere posicionamento privilegiado dentro do campo da Educação. A maior concentração de bolsistas está, respectivamente, nas categorias PQ 2 (214) e PQ-1D (80), o que sugere a seletividade nas mudanças para categorias e níveis mais elevados.

\section{2 .2}

\section{Nosso olhar sobre o objeto}

Produzindo um recorte da pesquisa do SOCED (Grupo de Pesquisas em Sociologia da Educação), coordenado pela pesquisadora Zaia Brandão, o estudo sobre a hierarquia das instituições a partir dos bolsistas de produtividade do $\mathrm{CNPq}$ emerge da releitura da pesquisa de doutorado "ANPEd e a preocupação da

17 Os dados dessa pesquisa exploratória com os bolsistas de produtividade $1 \mathrm{~A}$ e $\mathrm{Sr}$ estão publicados na Revista Educação e Pesquisa (USP-on-line) com o título "Operando com conceitos de Bourdieu: produtividade em pesquisa e hierarquias acadêmicas no campo da Educação"(COCK et al., 2018). 
autonomia: em busca de reconhecimento e consagração" (HENRIQUES, 1998) que retoma o histórico da criação da ANPEd (Associação Nacional de PósGraduação e Pesquisa em Educação) ${ }^{18}$ e do CNPq revelando o jogo de lutas concorrenciais entre as instituições e seus agentes na mobilização de uma política de desenvolvimento da pós-graduação e do fomento à pesquisa na área de Educação no final da década de 1990.

Utilizando como principal referencial teórico Pierre Bourdieu, a autora destaca as estratégias ${ }^{19}$ dentro do campo científico na criação da ANPEd que também estão imbricadas na (re)criação do CNPq compreendendo tais entidades como campo de forças que traziam a retórica pela autonomia como o reconhecimento do campo como instância de produção de conhecimento.

Cobrindo as primeiras décadas da vida da entidade, a Vera Henriques (1998) analisou a luta da ANPEd pela autonomia interna, através da participação nas definições das normas e políticas de avaliação dos órgãos oficiais (Capes e CNPq), contingenciando os recursos e o reconhecimento dos programas de pósgraduação em Educação.

A pesquisadora ressalta em sua tese o protagonismo de algumas instituições de ensino superior, públicas e privadas, que objetivaram ao longo das reuniões de criação da ANPEd e, posteriormente, do CNPq manter posições ou conjugar interesses com outras instituições para a divisão/alternância na ocupação de cadeiras nas reuniões de criação assim como nas funções de gestores da ANPEd revelando uma autonomia relativa com relação aos próprios agentes/pesquisadores inscritos na dinâmica de construção.

Vera Henriques (1998 p.142) destaca instituições das regiões Sul e Sudeste como predominantes nas dinâmicas de criação e representação na diretoria da ANPEd. PUC-Rio, IESAE, UFF e UFRJ são as instituições que coordenaram as duas reuniões de criação da ANPEd e UFRGS, IESAE, UFF e UFMG são as instituições com maior representação na diretoria da ANPEd no período de 1978 a 1995.

\footnotetext{
${ }^{18}$ ANPEd é uma sociedade civil, sem fins lucrativos, fundada em 1976 pela iniciativa de alguns programas de pós-graduação da área da Educação. Ela basicamente tem como finalidade a busca do desenvolvimento e da consolidação do ensino de pós-graduação e da pesquisa, na área da Educação, no Brasil.

${ }^{19}$ Bourdieu (2004a) entende que estratégia como produto do sentido prático. Para ele a noção de estratégia é o instrumento de ruptura com o ponto de vista objetivista e com a ação sem agente, suposta pelo estruturalismo (noção de inconsciente).
} 
Percebendo o jogo de disputas por poder político no interior da ANPEd (inclusive na formação dos Grupos de Trabalho - GTs ) e posteriormente na formação das CAs no CNPq, a autora faz um desenho da dinâmica do campo científico na área da Educação.

Hoje, passados mais de 30 anos da construção da ANPEd, como se encontra o campo científico na área da Educação? Quais foram as principais modificações nas hierarquias do campo científico na área? Quais instituições estão "predominando/dominando" o campo da Educação?

\subsection{3}

\section{A construção do recorte da pesquisa: condução do estudo, hipóteses e objetivos}

Visamos construir um desenho das hierarquias acadêmicas no campo da Educação através dos agentes, pois entendemos que "um cientista é o campo científico feito pessoa, cujas estruturas cognitivas são homólogas às estruturas do campo e, por essa razão, constantemente ajustadas às expectativas inscritas no campo" (BOURDIEU, 2005 p.35).

Partindo dos PQs nosso objetivo será traçar uma configuração das instituições ${ }^{20}$ prevalentes nessas trajetórias, para conhecer o peso relativo das instituições universitárias na luta por hegemonia no campo da Educação. A semelhança da pesquisa de Henriques (1998), o objeto da investigação são as instituições na composição das hierarquias científico-acadêmicas a partir das trajetórias institucionais e práticas acadêmicas registradas no Currículo Lattes dos pesquisadores bolsista de produtividade das categorias 1 (A, B, C, D) e Sênior.

A instituição investe naqueles que investiram nela e há um momento em que, pela dedicação, investimento de tempo, de trabalho e de "devoção a instituição", o agente torna-se instituição autorizado por esta a representá-la constituindo possibilidades de construção de capitais que possibilitam maior mobilidade no campo, como por exemplo, o capital político. (BOURDIEU, 1989)

A delegação do capital político pressupõe a adjetivação desta espécie de capital em instituições permanentes. A objetivação do capital político garante uma independência relativa, uma dominação imediata que permite que se mantenha

\footnotetext{
${ }^{20}$ Da mesma forma que Vera Henrique, em sua tese de doutorado (Henrique: 1998), a identidade dos pesquisadores 1 e Sêniors serão substituídas pelas instituições onde trabalham (ou se aposentaram, no caso dos Sêniors)
} 
duradouramente a posição de distinção de seus agentes e logo dos seus postos. Para Bourdieu (1989) quanto mais o capital político se institucionaliza em forma de posições ocupadas, maiores são as vantagens em entrar no aparelho.

Organizamos nossos dados no Excel e utilizamos o tratamento de dados do Excel e do SPSS para a análise ${ }^{21}$ das variáveis do nosso banco de dados dos PQ-1 e PQ-Sr caracterizando, pela instituição de pertença de cada agente, a hierarquia a partir da:

- Instituição e região ${ }^{22}$ da instituição de trabalho dos pesquisadores, considerando a hipótese da concentração do incentivo à pesquisa em Educação mais presente em algumas regiões do país;

- Instituição de doutoramento, considerando a hipótese da concentração de formação em algumas instituições e o capital simbólico incutido nessa pertença durante a formação para a pesquisa;

- Relação entre a instituição de formação (doutoramento) e a instituição de pertença, queremos compreender se existe uma mobilidade dentro da área científica em Educação preocupada em expandir a pesquisa educacional para todas as regiões do país;

- Relação entre os tipos de publicações e as posições ocupadas, para identificarmos se existe correlação entre as instituições que estão no topo da hierarquia com o volume das publicações;

- Conhecer as instituições responsáveis pelas revistas avaliadas com Qualis A1 e A2, visando conhecer se as hierarquias na manutenção do campo do poder se reproduzem também no que diz respeito às responsabilidades de gestão de periódicos relevantes na área da Educação;

- Relacionar a publicação em periódicos dos PQ1 e PQ-Sr e instituição de pertença das revistas, visando conhecer se existe um ciclo de legitimidade/autorização científica delegado a determinadas instituições através de seus periódicos.

\footnotetext{
${ }^{21}$ Para construção de nossas tabelas utilizamos a realização de tabulações cruzadas entre as variáveis que desejávamos relacionar ou frequência de determinada ocorrência conforme apontamos ao longo da apresentação da empiria.

22 Utilizaremos neste estudo a divisão regional do IBGE. Disponível em: http://www.ibge.gov.br/home/geociencias/geografia/default_div_int.shtm?c=1
} 


\section{3}

\section{Análises: Como está configurada a hierarquia acadêmica?}

Os dados empíricos produzidos são utilizados para o desenvolvimento de algumas hipóteses explicitadas anteriormente para nos ajudar a compreender a hierarquia no campo científico da pesquisa em Educação.

\subsection{A distribuições dos PQs por instituições e regiões do Brasil}

A Tabela 2 apresenta o quadro dos bolsistas PQ/CNPq e suas instituições por categoria. 
Tabela 2 - Instituição de cada bolsista de produtividade por categoria

\begin{tabular}{|c|c|c|c|c|c|c|}
\hline INSTITUIÇÃO & SR & $1 \mathrm{~A}$ & 1B & $1 \mathrm{C}$ & 1D & TOTAL \\
\hline USP & 2 & 5 & 3 & 7 & 5 & 22 \\
\hline UERJ & 0 & 2 & 3 & 2 & 7 & 14 \\
\hline UFMG & 1 & 5 & 2 & 1 & 5 & 14 \\
\hline UNESP & 0 & 3 & 2 & 3 & 6 & 14 \\
\hline UFRGS & 2 & 2 & 2 & 4 & 4 & 14 \\
\hline UFSCAR & 2 & 2 & 1 & 3 & 4 & 12 \\
\hline UFRJ & 1 & 2 & 2 & 1 & 3 & $\overline{9}$ \\
\hline Unicamp & 0 & 0 & 1 & 4 & 3 & 8 \\
\hline UNISINOS & 0 & 2 & 1 & 1 & 3 & 7 \\
\hline PUC/SP & 0 & 0 & 0 & 0 & 5 & 5 \\
\hline PUCRS & 0 & 2 & 1 & 0 & 2 & 5 \\
\hline PUC-Rio & 0 & 3 & 0 & 0 & 1 & 4 \\
\hline UFF & 0 & 1 & 0 & 1 & 2 & 4 \\
\hline UFPR & 0 & 1 & 1 & 0 & 2 & 4 \\
\hline UFSC & 0 & 0 & 1 & 1 & 2 & 4 \\
\hline UFU & 0 & 0 & 1 & 2 & 1 & 4 \\
\hline UFBA & 0 & 0 & 2 & 0 & 1 & 3 \\
\hline UFC & 1 & 0 & 0 & 0 & 2 & 3 \\
\hline UFRN & 0 & 0 & 0 & 0 & 3 & 3 \\
\hline UnB & 0 & 0 & 1 & 0 & 2 & 3 \\
\hline UNIFESP & 1 & 0 & 0 & 0 & 2 & 3 \\
\hline UEL & 0 & 0 & 0 & 1 & 1 & 2 \\
\hline UFPB & 0 & 0 & 0 & 0 & 2 & 2 \\
\hline UFPE & 0 & 0 & 0 & 0 & 2 & 2 \\
\hline UEM & 0 & 0 & 0 & 1 & 1 & 2 \\
\hline UFSM & 0 & 0 & 0 & 0 & 2 & 2 \\
\hline FURG & 0 & 0 & 0 & 1 & 0 & 1 \\
\hline PUC-Campinas & 1 & 0 & 0 & 0 & 0 & 1 \\
\hline PUC-Goiás & 0 & 0 & 0 & 0 & 1 & 1 \\
\hline UECE & 0 & 0 & 1 & 0 & 0 & 1 \\
\hline UEPG & 0 & 0 & 0 & 0 & 1 & 1 \\
\hline UFAL & 0 & 0 & 0 & 0 & 1 & $\overline{1}$ \\
\hline UFES & 0 & 0 & 0 & 0 & 1 & 1 \\
\hline UFJF & 0 & 0 & 0 & 0 & 1 & 1 \\
\hline UFPA & 0 & 0 & 0 & 0 & 1 & 1 \\
\hline UFPEL & 0 & 0 & 0 & 0 & 1 & 1 \\
\hline UNEB & 0 & 0 & 0 & 0 & 1 & 1 \\
\hline UTP/PR & 0 & 0 & 0 & 1 & 0 & \\
\hline & 11 & 30 & 25 & 34 & 81 & 181 \\
\hline
\end{tabular}

Fonte: banco de dados SOCED / Plataforma Lattes - CNPq, 2016.

Apesar de observarmos a presença de 38 instituições com bolsistas de produtividade, observamos que há concentração de pouco mais de $50 \%$ desses bolsistas em apenas 7 instituições, conforme a tabela 3 .

A leitura desses dados nos suscitou pensar nas estratégias que são utilizadas para a manutenção da posição relativa de quem está, ou sempre esteve, no topo 
das hierarquias e das que se pode ter para chegar lá. No campo intelectual, independentemente das hierarquias de bolsas PQs, sempre existem hierarquias de posições no tocante à legitimidade que nunca se manifestam inteiramente ao nível da consciência dos agentes por não terem seu princípio globalmente situado dentro do próprio campo.

Tabela 3 - Distribuição das Instituições com maior concentração de $\mathrm{PQ} / \mathrm{CNPq}^{23}$

\begin{tabular}{|l|c|c|c|c|c|c|}
\hline INSTITUIÇÃO & SR & 1A & 1B & 1C & 1D & TOTAL E \% \\
\hline USP & 2 & 5 & 3 & 7 & 5 & $22(12,3 \%)$ \\
\hline UERJ & 0 & 2 & 3 & 2 & 7 & $14(7,7 \%)$ \\
\hline UFMG & 1 & 5 & 2 & 1 & 5 & $14(7,7 \%)$ \\
\hline UNESP & 0 & 3 & 2 & 3 & 6 & $14(7,7 \%)$ \\
\hline UFRGS & 2 & 2 & 2 & 4 & 4 & $14(7,7 \%)$ \\
\hline UFSCAR & 2 & 2 & 1 & 3 & 4 & $12(6,6 \%)$ \\
\hline UFRJ & 1 & 2 & 2 & 1 & 3 & $9(5 \%)$ \\
\hline $\begin{array}{l}\text { Total parcial (cerca } \\
\text { de 50\% da } \\
\begin{array}{l}\text { concentração de } \\
\text { bolsistas) }\end{array}\end{array}$ & 8 & 21 & 15 & 21 & 34 & $99(54,7 \%)$ \\
\hline OUTRAS & 3 & 9 & 10 & 13 & 47 & $82(45,3 \%)$ \\
\hline TOTAL & 11 & 30 & 25 & 34 & 81 & $181(100 \%)$ \\
\hline
\end{tabular}

Fonte: banco de dados SOCED / Plataforma Lattes - CNPq, 2016.

Conforme a tabela 3, as instituições universitárias que abrangem o maior número de bolsistas situam-se nas regiões Sudeste e Sul, como resultado do acúmulo de recursos econômicos, sociais e políticos que tradicionalmente caracterizam estas instituições e estas regiões.

As sete primeiras instituições da tabela (USP, UERJ, UFMG, UNESP, UFRGS, UFSCar e UFRJ) concentram 54,7\% (99) dos PQs. Ao analisarmos as categorias, especialmente dados sobre os bolsistas de produtividade Sêniors e 1A, observamos que essas sete instituições possuem pelo menos dois bolsistas nessas categorias e percebemos quatro instituições (USP (7), UFMG (6), UFRGS (4), UFSCAR (4)) que concentram 51, 4\% (21) dos PQ-Sr e 1A.

O fato desses 21 pesquisadores estarem concentrados na USP, UFMG, UFRGS, UFSCAR nos trazem pistas da representatividade do poder simbólico destas instituições na construção das hierarquias acadêmicas. Tais instituições

23 A categoria OUTRAS, na tabela 3, agrupa 31 instituições que apresentavam número reduzido de $\mathrm{PQ} / \mathrm{CNPq}$, num total de 82 pesquisadores. 
parecem ter exercido um pioneirismo, especialmente por ter alguns pesquisadores titulados no exterior, conforme veremos adiante na tabela 8. Podemos dizer que, por serem as mais representadas entre os pesquisadores da elite do campo acadêmico-científico da Educação, tais instituições se encontram no topo da hierarquia neste campo.

Tabela 4 - Instituições dos pesquisadores PQ-1A e PQ-Sr da Educação

\begin{tabular}{|c|c|c|c|}
\hline $\begin{array}{c}\text { INSTITUIÇÕES } \\
\text { ATUAIS }\end{array}$ & $\begin{array}{c}\text { N DE } \\
\text { PESQUISADORES }\end{array}$ & \% & $\begin{array}{c}\text { \% } \\
\text { CUMULATIVO }\end{array}$ \\
\hline USP & 7 & 17,1 & 17,1 \\
\hline UFMG & 6 & 14,6 & 31,7 \\
\hline UFRGS & 4 & 9,7 & 41,4 \\
\hline UFSCar & 4 & 9,7 & 51,1 \\
\hline UFRJ & 3 & 7,4 & 58,5 \\
\hline PUC-Rio & 3 & 7,4 & 65,9 \\
\hline UNESP & 3 & 7,4 & 73,3 \\
\hline UERJ & 2 & 4,9 & 78,2 \\
\hline UNISINOS & 2 & 4,9 & 83,1 \\
\hline PUC-RS & 2 & 4,9 & 88 \\
\hline PUC-Campinas & 1 & 2,4 & 90,4 \\
\hline UFC & 1 & 2,4 & 92,8 \\
\hline UFF & 1 & 2,4 & 95,2 \\
\hline UFPR & 1 & 2,4 & 97,6 \\
\hline UNIFESP & 1 & 2,4 & 100 \\
\hline Total & $\mathbf{4 1}$ & $\mathbf{1 0 0}$ & \\
\hline
\end{tabular}

Fonte: banco de dados SOCED / Plataforma Lattes - CNPq, 2016.

Conforme a tabela 4, sobre as instituições dos PQ-1A e PQ-Sr, inferimos o poder da tradição e da consolidação da pesquisa nessas instituições, que estão entre as pioneiras na criação da pós-graduação e da $\mathrm{ANPEd}^{24}$, ocupando ainda hoje, lugar de destaque na área da pesquisa em Educação.

\subsection{A distribuição dos $\mathrm{PQs}$ por regiões do Brasil}

Observando a representatividade das instituições da região Sudeste e Sul, resolvemos seguir nossas análises observando a quantidade de bolsistas de produtividade distribuídos por categoria entre as regiões do Brasil.

${ }^{24}$ O primeiro curso de mestrado em Educação foi criado na PUC-Rio em 1965. Ver a respeito da criação da ANPED a tese de doutorando de Vera Henriques (1998), membro do SOCED. 
Tabela 5 - Bolsistas de Produtividade em Pesquisas por regiões do Brasil

\begin{tabular}{|c|c|c|c|c|c|c|}
\hline $\begin{array}{c}\text { REGIÕES } \\
\text { DO } \\
\text { BRASIL }\end{array}$ & SR & 1A & 1B & 1C & 1D & TOTAL e \% \\
\hline SE & 8 & 23 & 15 & 24 & 46 & $116(64 \%)$ \\
\hline S & 2 & 7 & 6 & 10 & 19 & $44(24,5 \%)$ \\
\hline NE & 1 & 0 & 3 & 0 & 12 & $16(8,8 \%)$ \\
\hline CE & 0 & 0 & 1 & 0 & 3 & $4(2,2 \%)$ \\
\hline N & 0 & 0 & 0 & 0 & 1 & $1(0,5 \%)$ \\
\hline Total & 11 & 30 & 25 & 34 & 81 & $181(100 \%)$ \\
\hline
\end{tabular}

Fonte: banco de dados SOCED / Plataforma Lattes - CNPq, 2016.

$\mathrm{Na}$ tabela 5 quase totalidade dos bolsistas $(88,5 \%)$ encontra-se nas regiões Sudeste e Sul. As outras três regiões do país concentram apenas 11,5\% dos bolsistas. Esta disparidade entre as regiões tende a permanecer, inclusive em função das bolsas de pós-graduação solicitadas pelos candidatos para se qualificarem nos programas de pós-graduação que obtêm as melhores avaliações pela Capes e possuem capital simbólico de distinção.

O capital simbólico enquanto elemento de distinção, assim como todas as formas de identidade coletiva reconhecida, são produtos de longa e lenta elaboração coletiva, lutas internas na construção e participação de uma história que no caso do campo da pesquisa em Educação pode ser materializada na criação da pós-graduação, da ANPEd e outras entidades de poder e/ou regulação da área, em especial, CNPq e Capes.

Considerando a necessidade de atentarmos as assimetrias regionais criamos o Quadro 1 com o atual quantitativo de programas de pós-graduação em Educação por região.

\section{Quadro 1 - Número de Programas de Pós-Graduação por região}

\begin{tabular}{|c|c|c|c|c|c|}
\hline NORTE & NORDESTE & CENTRO-OESTE & SUDESTE & SUL & TOTAL \\
\hline 14 & 34 & 16 & 70 & 44 & 178 \\
\hline
\end{tabular}

Fonte: Plataforma $\quad$ Sucupira $\quad$ Disponível em:
https://sucupira.capes.gov.br/sucupira/public/consultas/coleta/programa/listaPrograma.jsf. Acesso em: $5 / 11 / 2018$.

Embora possamos ver no Quadro 1 que todas a regiões do país possuem programas de pós-graduação reconhecidos em funcionamento, dentre os 178 apenas 64 estão nas regiões Norte, Nordeste e Centro-Oeste sendo inferior até mesmo ao número total de programas de pós-graduação concentrados na região Sudeste, com 70 programas. 
De certo, a proximidade entre as regiões Sul e Sudeste e a participação destas na criação da ANPEd, instituição de presença forte e ativa no momento inicial de criação dos órgãos reguladores e financiadores da pós-graduação e da pesquisa no país, como a Capes e o CNPq, podem ter contribuído para fortalecer e ampliar os programas de tais regiões em detrimento de outras.

Apesar dos Planos Nacionais de Pós-Graduação (PNPGs) estipularem, desde o primeiro documento, a necessidade capacitar e qualificar os profissionais e evitar desigualdades regionais parece que a forma de distribuir recursos contribui para que tais desigualdades persistem até hoje (FRANÇA, 2014).

As delegações de poder para algumas instituições pioneiras na criação da ANPEd e da pós-graduação pode ter contribuído para aquilo que o autor chama de "o mistério do ministério" 25 , no qual a instituição do poder e da tradição da área torna-se referência e aspiração para acumulação de capitais (BOURDIEU, 1989).

No Quadro $2^{26}$ temos um levantamento divulgado pela Capes com o quantitativo de bolsas distribuídas para todos os estudantes de pós-graduação stricto-sensu do Brasil. Ao observarmos a distribuição por estados vemos que apesar de todos receberem bolsas, há uma grande quantidade investida nos grandes estados da região Sul (com 11.133 bolsas de PG) e Sudeste (43.496 bolsas de PG), especialmente em São Paulo que concentra 22.635 bolsas (10.265 bolsas de mestrado e 12.370 bolsas de doutorado).

A concentração e o volume de recursos nas duas regiões do país derivam da densidade populacional do Sudeste (de pouco mais de 80 milhões de habitantes) e dos recursos disponibilizados a este grande contingente populacional assim como do fato da região Sul ser a segunda região mais rica do país. A região Sul com 26 milhões de habitantes possui o maior IDH (Índice de Desenvolvimento Humano), a maior taxa de alfabetização e os melhores níveis de Educação, saúde e bem-estar social do país, logo há maiores chances de alcançar os níveis mais elevados de Educação.

\footnotetext{
${ }^{25}$ Para Bourdieu (1998 p.158) "O mistério do ministério é um desses casos de magia social em que uma coisa ou uma pessoa se torna uma coisa diferente daquilo que ela é (...).”.

${ }^{26}$ Apesar de não reproduzir neste trabalho, considero relevante o quadro elaborado por Gatti (1993) com os dados da Capes em 1982 ainda no processo inicial da pós-graduação mostrando as disparidades regionais na concessão de bolsas e afirmando sobre a distribuição desigual que "Compreende-se que haja programas privilegiados por terem tradição e competência, mas uma análise mais detalhada quanto aos procedimentos de concessão de bolsas parece necessária". (GATTI, 1983, p.10)
} 
Durante toda nossa pesquisa não perdemos de vista que as disparidades regionais possuem uma raiz estrutural relacionada a investimentos de outras ordens e dentre tais de oportunidade e qualidade de ensino que requerer análises que ultrapassaria os limites do objeto tratado nesta pesquisa. 
Quadro 2 - Distribuição de bolsas de pós-graduação por estado em todas as áreas

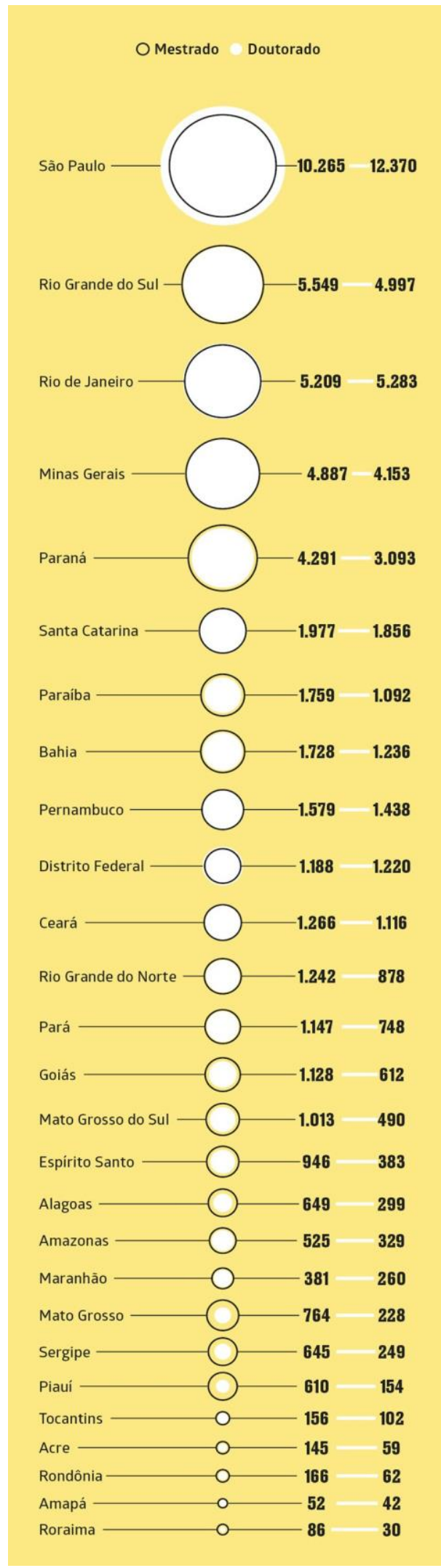

Fonte: Capes - 2015 Disponível em: https://revistagalileu.globo.com/Revista/noticia/2017/08/oque-voce-precisa-saber-sobre-pos-graduacao-no-brasil.html. Acesso em: 28/12/2018. 
As distâncias físicas e econômicas entre o Sul/Sudeste e o restante do país dificilmente serão superadas nas próximas décadas; sobretudo pela tendência do poder atrair mais poder, no caso da ciência, conforme assinalou Merton, ao definir o "Efeito Matheus"27 fazendo uma analogia à passagem bíblica: "A todo aquele que tem, será dado mais, e terá em abundância. Mas ao que não tem, até o que tem lhe será tirado." (MATEUS, 25, 28-29) ${ }^{28}$. Trata-se de uma existência simbólica dessas instituições dotada de sentido e valor dentro do campo seja pelo poder simbólico, seja pelo capital político acumulado.

O poder simbólico é um poder que aquele que lhe está sujeito dá àquele que o exerce, um crédito com que ele o credita, uma fides, uma auctoritas, que ele lhe confia pondo nele a sua confiança. É um poder que existe porque aquele que lhe está sujeito crê que ele existe. (BOURDIEU, 1989 p.188)

Ao observarmos a tabela 5 é perceptível um filtro até os níveis mais elevados da hierarquia de PQ/CNPq (Sênior e $1 \mathrm{~A}^{29}$ ). Podemos notar a baixa expressividade de bolsistas das regiões Norte, Nordeste e Centro-Oeste, menos apoiadas com recursos para a pesquisa. Essas regiões contam com apenas 11,6\% (21) bolsistas do total de 181 PQs. Destes, 16 pesquisadores estão na categoria 1D, nível inicial dos $\mathrm{PQ} / \mathrm{CNPq}$ da categoria 1; quatro pesquisadores na categoria 1B; e apenas um na categoria SR, representante da primeira geração de pesquisadores do $\mathrm{CNPq}$, com o doutorado no exterior, antes da criação das pósgraduações em Educação no Brasil.

Convergindo com nossas hipóteses, o site da Carta Campinas $^{30}$ apresenta o relatório Research in Brazil $^{31}$, disponibilizado pela Clarivate Analytics à Coordenação de Aperfeiçoamento de Pessoal de Nível Superior (Capes) apresentando gráficos que permitem visualizarmos o cenário da produção científica no país afirmando que a produção científica nacional é dependente das universidades públicas.

\footnotetext{
${ }^{27}$ Ver a respeito: Merton, R. (1968) The Matheus Effect.

${ }^{28}$ Disponível em: https://www.bibliaonline.com.br/acf/mt/25/28,29+. Acesso em: 2/02/2018.

${ }^{29}$ Mesmo tendo vagas para o nível 1A (das 395 vagas apenas 30 estão ocupadas e tendo em vista o calculo de $10 \%$ do total de pesquisadores em todas as categorias, sobram 9 vagas) há uma dificuldade de penetração dos agentes dessas regiões do país na "elite da elite".

30 Disponível em: http://cartacampinas.com.br/2018/01/xrelatorio-internacional-mostra-queuniversidade-particular-no-brasil-nao-produzem-conhecimento/. Acesso em: 5/02/2018.

31 Para acessar o relatório completo "Research in Brazil: A report for CAPES by Clarivate Analytics" ver: http://www.capes.gov.br/images/stories/download/diversos/17012018-CAPESInCitesReport-Final.pdf. Acesso em: 5/2/2018.
} 
$\mathrm{O}$ documento que apresenta o desempenho da pesquisa brasileira em um contexto global entre os anos 2011 e 2016 mostra o papel das universidades públicas para o desenvolvimento científico e faz críticas as universidades privadas no que se refere à produção do conhecimento. Sem debater as questões implícitas e polêmicas da matéria, olhando para nosso objeto de estudo poderemos ver que, em todas as áreas de conhecimento, as regiões Sul e Sudeste ainda apresentam posições de destaque no cenário acadêmico. As instituições que apresentamos como as principais instituições do campo do poder na área da pesquisa em Educação estão entre as principais instituições de produção de conhecimento do país, conforme quadro 3 e 4 .

\section{Quadro 3 - Desempenho das principais universidades brasileiras em pesquisa $^{32}$}

\section{Desempenho das principais universidades brasileiras em pesquisa}

\section{Período 2011-2016}

\begin{tabular}{|l|r|}
\hline Universidade & \multicolumn{1}{|c|}{$\begin{array}{c}\text { Documentos na } \\
\text { Web of Science }\end{array}$} \\
\hline Univ. de Săo Paulo (USP) & 54.108 \\
\hline Univ. Estadual Paulista & 20.023 \\
\hline Univ. Estadual de Campinas & 17.279 \\
\hline Univ. Federal do Rio de Janeiro & 16.203 \\
\hline Univ. Federal do Rio Grande do Sul & 14.611 \\
\hline Univ. Federal de Minas Gerais & 13.294 \\
\hline Univ. Federal de São Paulo & 10.667 \\
\hline Univ. Federal do Paraná & 8.233 \\
\hline Univ. Federal de Santa Catarina & 7.908 \\
\hline Univ. do Estado do Rio de Janeiro & 6.433 \\
\hline Univ. Federal de Pernambuco & 6.420 \\
\hline Univ. Federal de Viçosa & 6.373 \\
\hline Univ. de Brasilla & 6.218 \\
\hline Univ. Federal de Săo Carlos & 5.794 \\
\hline Univ. Federal de Santa Maria & 5.750 \\
\hline Univ. Federal do Ceará & 5.621 \\
\hline Univ. Federal Fluminense & 5.441 \\
\hline Univ. Federal de Golás & 4.217 \\
\hline Univ. Federal da Bahia & 4.198 \\
\hline Univ. Estadual de Maringa & 4.067 \\
\hline & \\
\hline
\end{tabular}

\begin{tabular}{|c|c|c|c|c|}
\hline $\begin{array}{c}\text { Impacto } \\
\text { da citação }\end{array}$ & & $\begin{array}{l}\text { Artigos no } \\
\text { Top } 1(\%)\end{array}$ & $\begin{array}{l}\text { Artigos no } \\
\text { Top } 10(\%)\end{array}$ & \\
\hline & 0,93 & & & 7,96 \\
\hline & 0,79 & & & 6,10 \\
\hline & 0,94 & 1. & & 8,35 \\
\hline & 0,93 & & & 8,18 \\
\hline & 0,89 & 0, & & 6,6 \\
\hline & 0,88 & 0, & & 6,24 \\
\hline & 0,93 & 1. & & 6,15 \\
\hline & 067 & & & 5,31 \\
\hline & 0,91 & 0, & & 6,79 \\
\hline & 1,01 & & & 8,98 \\
\hline & 0,73 & & & 5,51 \\
\hline & 0,63 & & & 4,33 \\
\hline & 0,89 & & & 6,10 \\
\hline & 0,72 & & & 6,28 \\
\hline & 0,65 & & & 4,96 \\
\hline & 0,76 & & & 6,12 \\
\hline & 0,71 & & & 5,99 \\
\hline & 0,74 & 0. & & 5,90 \\
\hline & 0,81 & 0, & & 6,77 \\
\hline & 0,61 & & & 4,50 \\
\hline
\end{tabular}

Fonte: Research in Brazil - A report for CAPES by Clarivate Analytics - 2017

Fonte: http://cartacampinas.com.br/2018/01/xrelatorio-internacional-mostra-que-universidadeparticular-no-brasil-nao-produzem-conhecimento/ Acesso em: 5/2/2018.

\footnotetext{
${ }^{32}$ Os dados foram obtidos do InCites, plataforma baseada nos documentos (artigos, trabalhos de eventos, livros, patentes, sites e estruturas químicas, compostos e reações) indexados na base de dados multidisciplinar Web of Science - editada pela Clarivate Analytics (anteriormente produzida pela Thomson Reuters).
} 
Andrea Dias Victor em pesquisa sobre os bolsista de produtividade da área de Sociologia desenvolve, logo no início de seu trabalho, uma discussão sobre o efeito Mateus e acumulação de vantagens. Ela define a representatividade como parte da estratificação social da ciência visto "as avaliações por pares levarem em conta os resultados do passado mais do que os do presente denunciando uma desigualdade entre os cientistas engendrada pelo próprio sistema de reconhecimento" (VITOR, 2014 p.36).

Neste sentido, a notoriedade de tais instituições na produção do conhecimento científico do país, assim como maior número de citações conforme apresentado no quadro 3, representa credibilidade dos capitais simbólicos acumulados.

O quadro 4 apresenta o volume da produção por estados evidenciando onde estão concentrados os recursos para realização de pesquisas em diversas áreas de conhecimento. .

Podemos comparar a dinâmica de citações apresentadas nos quadros 3 e 4 com as solidariedades nos campos das quais nos fala o sociólogo francês. As solidariedades podem ser concebidas como a engrenagem de alianças que fazem funcionar o jogo que se joga nos campos. O "prazer" de estar no jogo pelas vantagens e o jogo de solidariedades para manter posições é um jogo político (BOURDIEU, 1998). 


\section{Quadro 4 - Desempenho em pesquisa por Estado}

\section{Desempenho em pesquisa por estado}

Período 2011-2016

\begin{tabular}{|c|c|c|c|c|}
\hline Estado & $\begin{array}{l}\text { Documentos na } \\
\text { Web of Science }\end{array}$ & $\begin{array}{l}\text { Impacto } \\
\text { da citaçâo }\end{array}$ & $\begin{array}{l}\text { Artigos no } \\
\text { Top } 1(\%)\end{array}$ & $\begin{array}{l}\text { Artigos no } \\
\text { Top } 10(\%)\end{array}$ \\
\hline São Paulo & \begin{tabular}{l|l} 
& 111.029 \\
\end{tabular} & 0,88 & 0,99 & 7,27 \\
\hline Rio de Janeiro & 39.996 & 0,93 & 1,15 & 7,80 \\
\hline Minas Gerais & 36.660 & 0,76 & 0,64 & 5,61 \\
\hline Rio Grande do Sul & 30.240 & 0,84 & 0,85 & 6,61 \\
\hline Paraná & 21.858 & 0,66 & 0,54 & 5,14 \\
\hline Santa Catarina & 12.312 & 0,84 & 0,63 & 6,08 \\
\hline Pernambuco & 10.589 & 0,71 & 0,54 & 5,18 \\
\hline Distrito Federal & 10.584 & 0,94 & 1,22 & 6,68 \\
\hline Bahia & 9.189 & 0,73 & 0,78 & 5,27 \\
\hline Ceará & 7.559 & 0,76 & 0,73 & 5,97 \\
\hline Paraiba & 6.276 & 0,64 & 0,45 & 4,70 \\
\hline Goisás & 5.929 & 0,73 & 0,78 & 5,45 \\
\hline Rio Grande do Norte & 5.474 & 0,75 & 0,62 & 5,06 \\
\hline Pará & 5.148 & 0,81 & 0,99 & 5,94 \\
\hline Espirito Santo & 3.837 & 0,63 & 0,60 & 4,56 \\
\hline Amazonas & 3.735 & 0,81 & 1,12 & 6,93 \\
\hline Mato Grosso do Sul & 3.541 & 0,56 & 0,34 & 3,33 \\
\hline Mato Grosso & 3.209 & 0,62 & 0,87 & 3,99 \\
\hline Sergipe & 2.658 & 0,72 & 0,56 & 5,38 \\
\hline Piauí & 2.066 & 0,53 & 0,15 & 3,87 \\
\hline Alagoas & 1.819 & 0,71 & 0,38 & 6,05 \\
\hline Maranhăo & 1.715 & 0,73 & 0,52 & 4,14 \\
\hline Tocantis & 900 & 0,49 & 0,22 & 2,56 \\
\hline Rondônia & 620 & 0,65 & 0,48 & 5,32 \\
\hline Acre & 452 & 0,83 & 1,99 & 8,41 \\
\hline Amapa & 391 & 0,68 & 0,51 & 5,37 \\
\hline Roraima & 349 & 0,74 & 1,15 & 4,87 \\
\hline
\end{tabular}

Fonte: Research in Brazil - A report for CAPES by Clarivate Analytics - 2017

Fonte: http://cartacampinas.com.br/2018/01/xrelatorio-internacional-mostra-que-universidadeparticular-no-brasil-nao-produzem-conhecimento/ Acesso em: 5/2/2018.

Os quadros 3 e 4 exprimem solidariedade entre as elites na qual as relações de poder e de interesse entre os cientistas "influenciam o processo de diferenciação e de acumulação de vantagens na ciência e no próprio conceito de notoriedade" (VICTOR, 2014, p.38).

\subsection{Os PQs e suas instituições de doutorado}

Nosso olhar para o pioneirismo das regiões Sudeste e Sul na qualificação dos pesquisadores levou-nos à construção da tabela 6 para identificar em quais instituições esses pesquisadores se doutoraram no Brasil e no exterior.

O capital, em estado incorporado, enquanto produto acumulado do trabalho passado e do pioneirismo científico destas instituições, é desfrutado por elas como um poder garantido no campo que gera vantagens em relação as outras que aos poucos entram no jogo. 
Para Bourdieu (1998), o título é capital simbólico que, dependendo do valor no campo, pode vir a representar o monopólio da violência simbólica legítima. A raridade simbólica do título confere capital que tende a se converter em vantagens e retribuições do campo pelo "mérito" na conquista dos títulos.

Ao olharmos para o nosso campo de estudo e pensarmos a relação entre as instituições que credenciaram como doutores os bolsistas de produtividade do CNPq, buscamos conhecer qual o poder das instituições e dos títulos no comando das regras do jogo e na construção das hierarquias acadêmicas da área da Educação.

Sobre o poder dos títulos nas lutas simbólicas, eles funcionam como capital simbólico institucionalizado, um nome que confere ao seu detentor todas as espécies de ganhos simbólicos.

Conforme observamos na tabela 2, enquanto, sete instituições estão no topo da representatividade entre os bolsistas, outras 31 instituições apesar de possuírem bolsistas talvez não tenham seus mecanismos de diferenciação situados propriamente no prestígio de suas instituições, mas nas relações construídas durante sua formação para a pesquisa, como no curso de doutoramento, por exemplo. Mais da metade dos pesquisadores (92) se formaram em três instituições da região Sudeste (tabela 6). 
Tabela 6 - Instituições no Brasil de doutoramento dos PQ/CNPq

\begin{tabular}{|l|c|c|c|c|c|c|}
\hline $\begin{array}{c}\text { INSTITUIÇÃO DO } \\
\text { DOUTORADO }\end{array}$ & 1A & SR & 1B & 1C & 1D & TOTAL \\
\hline USP & 8 & 1 & 7 & 13 & 19 & $48(26,6 \%)$ \\
\hline PUC/SP & 5 & 4 & 3 & 1 & 9 & $22(12,2 \%)$ \\
\hline UNICAMP & 1 & 0 & 3 & 9 & 9 & $22(12,2 \%)$ \\
\hline UFRGS & 3 & 1 & 2 & 6 & 3 & $15(8,3 \%)$ \\
\hline PUC-Rio & 4 & 0 & 0 & 0 & 5 & $9(5 \%)$ \\
\hline UNESP & 1 & 2 & 1 & 0 & 4 & $8(4,5 \%)$ \\
\hline UFRJ & 0 & 0 & 0 & 1 & 6 & $7(3,9 \%)$ \\
\hline UFMG & 0 & 0 & 1 & 0 & 3 & $4(2,2 \%))$ \\
\hline PUC/RS & 1 & 0 & 0 & 0 & 1 & $2(1,1 \%)$ \\
\hline UFBA & 0 & 0 & 0 & 0 & 2 & $2(1,1 \%)$ \\
\hline UFRN & 0 & 0 & 0 & 0 & 2 & $2(1,1 \%)$ \\
\hline Escola Superior de & 0 & 0 & 0 & 0 & 1 & $1(0,5 \%)$ \\
\hline Teologia & 0 & 0 & 0 & 0 & 1 & $1(0,5 \%)$ \\
\hline FGV & 0 & 0 & 0 & 0 & 1 & $1(0,5 \%)$ \\
\hline UFF & 0 & 0 & 1 & 0 & 0 & $1(0,5 \%)$ \\
\hline UFPR & 0 & 0 & 0 & 0 & 1 & $1(0,5 \%)$ \\
\hline UFSC & 23 & 8 & 18 & 30 & 67 & $146(80,7 \%)$ \\
\hline $\begin{array}{l}\text { Doutorado no País } \\
\text { (total) }\end{array}$ & 7 & 3 & 7 & 4 & 14 & $35(19,3 \%)$ \\
\hline $\begin{array}{l}\text { Doutorado no Exterior } \\
\text { (total) }\end{array}$ & & &
\end{tabular}

Fonte: banco de dados SOCED / Plataforma Lattes - CNPq, 2016.

Conforme a tabela 3 temos atualmente 38 instituições com bolsistas de produtividade e ao olharmos para as instituições de formação desses bolsistas, na tabela 6, observamos que 16 instituições no país formaram esses pesquisadores.

Nossos dados indicam que $51 \%$ dos bolsistas de produtividade em pesquisa do $\mathrm{CNPq}$ se doutoraram em apenas três universidades do país, e todas elas no Estado de São Paulo - USP (26,6\%), UNICAMP (12,2\%) e PUC/SP (12,2\%). Esta hegemonia paulista é compreensível não só pela tradição e pioneirismo da USP, criada em 1934 e formadora do primeiro grupo de sociólogos que se dedicaram à pesquisa da Educação no Brasil, mas sobretudo pela centralidade do desenvolvimento econômico e social do Estado de São Paulo, que até hoje concentra o dinamismo do mercado financeiro no país.

... a primeira e mais bem-sucedida universidade da década de 1930 não foi a Universidade Nacional no Rio de Janeiro, mas a universidade do Estado de São Paulo, conhecida até hoje como Universidade de São Paulo (USP), fundada em 1934. Durante muitas décadas, o Estado de São Paulo foi o mais importante pólo de crescimento econômico do país, primeiro como a principal região de plantio e exportação de café, mais tarde como um dinâmico centro industrial, que tirou proveito das habilidades empreendedoras do grande número de imigrantes europeus e de brasileiros oriundos de outras regiões.(SCHWARTZMAN, 2006, p.163) 
Ainda hoje, apesar de toda a ampliação dos programas de pós-graduação em Educação e das tentativas de deslocar o poder central do Sudeste do Brasil, com a criação de Brasília como capital do país, o poder não só econômico, como também científico, encontra-se fortemente ancorado no Sudeste e Sul, como nossos dados indicam.

Em artigo sobre a pós-graduação e a pesquisa em Educação no Brasil, Gatti (1983) realizou um levantamento (utilizando dados da Capes do ano de 1982) com os primeiros programas de pós-graduação a titularem doutores no país conforme podemos ver no quadro 5 .

Quadro 5 - Primeiros cursos de doutorado em Educação no Brasil

\begin{tabular}{|c|c|c|c|c|c|c|}
\hline INSTITUIÇÕES & ÁREAS & $\begin{array}{l}\text { ANO DE } \\
\text { INÍCIO }\end{array}$ & $\begin{array}{c}\mathrm{N}^{\mathbf{0}} \\
\text { ALUNOS } \\
(\mathbf{1 9 8 1 )} \\
\end{array}$ & ABANDONO & $\begin{array}{c}\text { BOLSA } \\
\text { ESTUDO }\end{array}$ & $\begin{array}{c}\text { TESES } \\
\text { DEFEND. }\end{array}$ \\
\hline UFRJ & $\begin{array}{l}\text { Educação } \\
\text { Brasileira }\end{array}$ & 80 & 16 & - & 3 & - \\
\hline PUC-Rio & $\begin{array}{l}\text { Psicologia } \\
\text { Educacional }\end{array}$ & 76 & - & - & 1 & - \\
\hline USP & $\begin{array}{l}\text { Hist. e Fil. da } \\
\text { Educação } \\
\text { Didática } \\
\text { Adm. Escolar }\end{array}$ & 78 & 26 & - & - & 2 \\
\hline UNICAMP & $\begin{array}{l}\text { Fil. E Hist. da } \\
\text { Educação }\end{array}$ & 75 & 7 & - & 1 & - \\
\hline $\mathrm{PUC} / \mathrm{SP}$ & $\begin{array}{l}\text { Filosofia da } \\
\text { Educação }\end{array}$ & 77 & 35 & 1 & 11 & 3 \\
\hline UFRGS & $\begin{array}{l}\text { Ensino- } \\
\text { aprendizagem }\end{array}$ & 76 & 7 & - & 1 & 2 \\
\hline TOTAL & & & 91 & 1 & 16 & 7 \\
\hline
\end{tabular}

Fonte: Reproduzido de Gatti (1983)/CAPES/82.

O quadro 5 revela que o pioneirismo na pós-graduação agregou capitais para as instituições que compõe nossa hierarquia dentre as instituições formadoras e de pertença dos bolsistas de produtividade. As instituições do quadro 3 são as principais formadoras do doutoramento dos PQs que analisamos.

Entendemos que o funcionamento e as funções sociais do campo de produção científica têm a seu cargo a conservação do capital de bens simbólicos legados pelos produtores do passado e consagrados pela sua conservação (instituição de formação e o reconhecimento dos pares principalmente) e, de outro lado, as instâncias qualificadas (instituições de ensino de pertença, por exemplo) que reproduzem os esquemas de percepção de apreciação dos bens simbólicos.

A lei que rege as permutas entre os agentes e as instituições pode enunciar-se assim: a instituição dá tudo, a começar pelo poder sobre a instituição, àqueles que 
tudo deram à instituição, mas porque fora da instituição e sem a instituição eles nada seriam, e porque não podem negar a instituição sem se negarem a si mesmo pura e simplesmente privando-se de tudo o que eles são pela instituição e para a instituição à qual tudo devem. (BOURDIEU, 1989 p.192)

Analisando o sistema de concessão de bolsas de produtividade em pesquisa (PQs) na área de Sociologia, Victor (2014) observa a tendência de concentração de recursos e benefícios para os pesquisadores que são ou que tenham sido bolsistas, resgatando assim a ideia da notoriedade e "consagração" através da bolsa de PQ, ou seja, o poder que gera poder, elucidando o Efeito Mateus da Sociologia Mertoniana. Para a autora $(2014$, p.42) a notoriedade adquirida a partir de determinados "capitais" podem constituir elementos de distinção simbólica que, em algum momento, desencadearão um "automatismo nas avaliações e concessões de recursos e outras premiações.".

Sobre a expressão do pioneirismo paulista, podemos mencionar que a USP, com seus 22 bolsistas, foi responsável pelo doutoramento de outros $26,6 \%$, ou seja, 48 bolsistas em produtividade da categoria 1 do CNPq. Os dados até o momento indicam a manutenção do potencial de produção de novos pesquisadores -pelas instituições que se destacam na estrutura hierárquica do mundo acadêmicoequipados para a disputa por posições de destaque no campo da pesquisa, compatíveis com o prestígio e poder consolidado por esses agentes institucionais.

Sobre a criação da ANPEd estudos de Henriques (1998) e Hey (2008) mostram a ausência da USP dentre as instituições com cursos de mestrado em Educação que se reuniram para a criação da entidade ${ }^{33}$. Hey (2008, p.140) ressalta "a ausência de professores da USP e de outras universidades estaduais de São Paulo no fomento à criação da ANPEd, apesar de estas universidades já possuírem cursos de doutorado na área" inferindo que "isto pode ser um indicador de conflitos entre este grupo e aqueles envolvidos com a CAPES e a organização da associação.”.

A USP ao longo do tempo conquistou seu espaço e construiu relações que a levou a posicionar-se no campo. A pesquisa de Hey (2008) em determinado momento destaca o papel científico e político da USP, especialmente por meio do

\footnotetext{
${ }^{33}$ Coordenadores dos programas de mestrado da UFC, UFPe, UFRJ, UFMG, UFF, UFSCar, UFBa, UnB, UFRGS, PUC-RS, PUC-Rio e FGV-IESAE se reuniram no Rio de Janeiro para discutir organização, funções e funcionamento da entidade elaborando em 1977 um anteprojeto de estatuto para a ANPEd que foi encaminhado para a CAPES e ficou engavetado até 1978. Ver mais em HEY (2008); HENRIQUES (1998).
} 
NUPES (Núcleo de Pesquisas sobre o Ensino Superior, atualmente NUPPs), no cenário brasileiro na década de 1970. Entendemos que a manutenção das posições destacadas da USP visam garantir a distinção e o poder político de tal instituição nas instâncias decisórias do campo.

As posições legitimadas pelo Estado permitem aos agentes participarem da esfera decisória das "regras do jogo" (comissões e similares) que por sua vez possibilitam a manutenção e ampliação das posições de poder dentro do campo (efeito Matheus).

O conceito (Efeito Mateus) retrata uma situação em que alguns indivíduos ou grupos se beneficiam e continuam a se beneficiar ao longo do tempo de reconhecimento, no sentido de credibilidade que se converte em habilidades instrumentais, e premiações em função de um reconhecimento passado, que envolve características acumuladas, adquiridas, como, filiação institucional, especialidades, quantidade e qualidade de premiações, que acaba por se tornar uma característica atribuída, julgada, quase que automaticamente, como meritória. (VICTOR, 2014 p.39)

Merton (1968) desenvolveu a preocupação em analisar o ethos científico colocando como problemática a "diferenciação a partir do sistema de premiação e dos critérios utilizados para a distribuição do reconhecimento" (VITOR, 2014, p.6). Segundo a mesma autora (op. cit p.7) "a notoriedade e o reconhecimento tendem a atrair mais notoriedade e mais reconhecimento e, em alguns casos esse reforço independe do desempenho dos cientistas no momento de avaliações" (negrito nossos).

Afirmações como essas situam-se na perspectiva de Bourdieu (2004) de que "a ciência é um campo como os outros quaisquer" em que há interesse em parecer desinteressado, ou seja, a serviço exclusivamente do conhecimento científico. Em que pese nossa concordância de que não há "ciência "pura", estamos convencidos de que há o interesse da ciência em produzir conhecimento válido para o campo específico, mas que este conhecimento não é nunca desprovido do objetivo de interessar os pares e concorrentes e, portanto, produzir efeitos positivos para o campo e para a sua própria posição dentro dele.

A PUC/SP possui entre seus pesquisadores nomes bastante conhecidos na área seja pela atuação científica seja pela atuação política ou ambas que, inegavelmente, confere capital simbólico para os agentes e instituição. "A ciência e a política andam juntas, sendo contrários aparentes. “(HEY, 2008, p.164) 
$\mathrm{Na}$ edição comemorativa dos 40 anos de institucionalização da pósgraduação em educação a Revista Brasileira de Educação traz um artigo de Dermeval Saviani (2005) sobre o protagonismo do professor Joel Martins ${ }^{34}$ na criação da pós-graduação no Brasil. Demonstrando a articulação política do pesquisador e sua participação em diferentes esferas do processo de institucionalização e funcionamento da pós-graduação no país, Saviani (2005) relata que, preocupado com a qualificação do quadro docente, Joel foi o principal articulador e incentivador dos estudos pós-graduados e do desenvolvimento de pesquisas na PUC/SP. É inegável que tal protagonismo criou uma rede na qual as universidades paulistas foram privilegiadas por ser uma das primeiras a atender o parecer Newton Sucupira ${ }^{35}$ e poder formar quadros de universidades e programas de pós-graduação.

Saviani (2005, p.29) relata que, com seu orientador Joel Martins, "a pósgraduação da PUC/SP tornou-se uma referência nacional, que rapidamente atraiu a atenção do governo federal" e ainda completa falando da atuação de Joel Martins em programas paulistas como o da Unicamp (que está entre as três instituições que mais formaram PQs 1) onde recebeu título de professor emérito. De fato, é inegável a importância de Joel para a história da pós-graduação e especialmente para a consolidação dos programas das instituições paulistas.

Conforme a tabela 6 , dos 22 pesquisadores bolsistas de produtividade titulados pela PUC/SP, seis tiveram como orientador Dermeval Saviani. Podemos inferir que o reconhecido papel de Dermeval Saviani na área e sua vinculação institucional a PUC/SP tenha importância para entendermos a quantidade de pesquisadores que buscaram esta instituição e este pesquisador para a titulação de doutorado. Talvez o capital simbólico e relacional para a formação com este pesquisador tenha pesado bastante para a construção da posição de tais pesquisadores em suas respectivas universidades e também como bolsista de

\footnotetext{
${ }^{34}$ Joel Martins a convite de Anísio Teixeira integrou o grupo que criou os Centros Regionais de Pesquisas Educacionais, foi diretor do braço paulista do Centro Brasileiro de Pesquisas Educacionais (CBPE); atuou como especialista na Organização das Nações Unidas para a Educação, a Ciência e a Cultura (UNESCO) e; na Organização dos Estados Americanos (OEA). $\mathrm{Na}$ PUC/SP, além de liderar a organização da pós-graduação e presidir a Comissão Geral do Setor de Pós-Graduação durante vários anos, Joel constituiu um grupo de apoio didático-pedagógico visando promover uma reflexão permanente sobre o caráter educativo da prática docente de todas as carreiras universitárias. (SAVIANI, 2005 p.30)

${ }^{35}$ O parecer CFE $n^{\circ}$ 977/65, aprovado em 3 dez. 1965, mais conhecido como parecer Newton Sucupira conceitua e define as características da pós-graduação a ser implantada no Brasil. Para mais informações ver: http://www.scielo.br/pdf/rbedu/n30/a14n30.pdf. Acesso em 12/12/2018.
} 
produtividade. Poderia se aquilo que Bourdieu (1998 apud HEY, 2008 p.165) define como "competência objetivada no título da instituição à qualidade da pessoa".

As instituições que concentram maior número de bolsistas de produtividade do $\mathrm{CNPq}$ constituem o campo do poder como uma rede cruzada de ligações estruturais e funcionais. Há destaques posicionais tanto em virtude da primazia no movimento de criação da pós-graduação em Educação (quando as regras do jogo eram bem menos complexas) quanto das solidariedades que convergem interesses específicos (parcerias, indicações em entidades políticas e comissões da área, publicações em revistas, etc.) que fortalecem a legitimidade de determinadas instituições e, consequentemente, seus agentes. Elas detêm "trunfos", diferenciais que garantem aos seus ocupantes força social e capitais específicos que os possibilitam lutar pela manutenção de posições privilegiadas dentro da hierarquia acadêmica e pelo poder de ditar "as regras do jogo".

De facto, a cena que se representa no palco, as estratégias que os agentes empregam para levarem a melhor na luta simbólica pelo monopólio da imposição do veredicto, pela capacidade reconhecida de dizer a verdade a respeito do que está em jogo no debate, são a expressão das relações de força objectivas entre os agentes envolvidos e, mais precisamente, entre os campos diferentes em que eles estão implicados - e em que ocupam posições mais ou menos elevadas. Dito por outras palavras, a interacção é a resultante visível e puramente fenomênica, da intersecção dos campos hierarquizados. (BOURDIEU, 1989, p. 55)

O poder simbólico possuído pelas instituições geram interesse nos “jogadores”/pesquisadores, no sentido estratégico nem sempre plenamente consciente. Tal poder no campo possui um quantum de força que permite sua manutenção ao longo do tempo gerando uma tradição de tais instituições no campo acadêmico e fazendo com que sejam, via reconhecimento, cada vez mais autorizadas a comandarem o jogo. O poder institucional é via para alcançar o poder político no âmbito acadêmico (HEY, 2008).

As ações do cientista correspondem à estrutura institucional que legitima um sistema de valores que permitem que elas ocorram. Trata-se de um efeito institucional, aquilo que Bourdieu (2014) chama de "efeito de contaminação simbólica", uma dinâmica de favorecimento mútuo. As instituições selecionam para seus cursos de doutorado os melhores alunos com potencial de inserção na comunidade científica que por sua vez reforçam a posição de destaque no campo e divulgam ainda mais os conhecimentos e os pesquisadores de tal instituição 
(direta ou indiretamente). De fato, "o êxito de uma carreira universitária passa pela "eleição" de um patrocinante poderoso, que não é necessariamente o mais famoso, nem sequer o mais competente tecnicamente" (BOURDIEU, 2014 p.126)

Nas tabelas 7, 9, 10, 11 e 12 veremos a posição destacada de algumas instituições que formaram pesquisadores de outras instituições e possibilitaram a construção de uma rede que abordaremos de acordo com os níveis dos PQs observando a relação entre instituição atual e instituição do doutorado.

Tabela 7 - Relação entre instituição atual e instituição na qual cursou o doutorado PQ-1A

\begin{tabular}{|l|l|}
\hline \multicolumn{1}{|c|}{ INSTITUIÇÃO ATUAL DOS PQ-1A } & \multicolumn{1}{|c|}{$\begin{array}{c}\text { INSTITUIÇÃO NA QUAL O PQ-1A } \\
\text { CURSOU O DOUTORADO }\end{array}$} \\
\hline 5 USP & 4 USP \\
& 1 PUC/SP \\
\hline 5 UFMG 5 & 3 USP \\
& 1 PUC/SP \\
& 1 EXT. \\
\hline 3 PUC-RIO 3 & 2 PUC-RIO \\
& 1 EXT. \\
\hline 3 UNESP 3 & 1 EXT. \\
& 1 UNESP \\
& 1 USP \\
\hline 2 UFRJ & 2 EXT. \\
\hline 2 UERJ & 1 EXT. \\
& 1 PUC/SP \\
\hline 2 UFRGS & 1 EXT. \\
\hline 2 UNISINOS & 1 UFRGS \\
\hline 2 UFSCAR & 1 PUC/RS \\
& 1 UNICAMP \\
\hline 2 PUC/RS & 1 PUC-RIO \\
\hline 1 UFPR & 1 PUC/SP \\
\hline 1 UFF & 2 UFRGS \\
\hline & 1 PUC-SP \\
\hline & 1 PUC-RIO \\
\hline
\end{tabular}

No nível 1A há seis pesquisadores titulados no exterior. Mas foi a USP que mais formou PQ-1A (7). Ela formou quatro PQs-1A da própria USP e três da UFMG que podem revelar o elo entre essas duas instituições que ao longo do tempo podem ter criados laços de solidariedade para fortalecerem-se no sistema e gerarem o acúmulo de vantagens em relação a outras instituições no campo do poder e no campo político. Tais relações podem ter contribuído para a afirmação do poder de participação/influência nas decisões da área e para manutenção e fortalecimento de suas respectivas posições.

Depois da USP, a instituição que mais formou doutores PQs no país foi a PUC/SP. A PUC/SP formou cinco PQs-1A distribuídos em diversas instituições. 
Ao observar a tabela 7 veremos que, apesar de não possuir nenhum bolsista nestas categorias -1A e Sr- (talvez por conta de seus pesquisadores já terem saído destas categorias do CNPq), é a PUC/SP que formou pesquisadores da categoria PQ-1A de instituições bastante representativas (com mais bolsistas de produtividade conforme a tabela 3) - com exceção da UFPR -, são elas: USP, UFMG, UERJ, UFSCAR , UFPR. Conforme já assinalado, a PUC/SP é uma instituição bastante importante no cenário da pós-graduação e pesquisa em Educação, especialmente pela atuação do professor Joel Martins e sua preocupação em doutorar os pesquisadores conforme assinala Saviani (2005 p.27-28):

Estávamos, então, no início de 1968. Naquele momento Joel Martins já despontava como o principal articulador e incentivador dos estudos pós-graduados e do desenvolvimento de pesquisas na PUC/SP, pois desde o ano anterior ele vinha procurando enfrentar "a necessidade urgente de preparar os escalões da universidade" (SILVA, 1993 p. 12). Para isso ele articulou junto à reitoria a criação de um regime de doutoramento, que depois veio a se chamar de "regime antigo", para viabilizar a obtenção do doutorado aos professores da universidade. Isso porque, segundo ele, havia "muita gente madura, dentro da instituição, para fazer um doutoramento. Gente com experiência didática, com experiência de pesquisa, com publicação etc." (idem, ibidem).

Analisando as instituições de doutoramento (origem) dos pesquisadores $1 \mathrm{~A}$ e Sênior (Tabela 8), observamos que mais da metade dos pesquisadores $(61,9 \%)$ realizaram o doutorado em apenas quatro instituições brasileiras: PUC/SP, USP, PUC-Rio e UFRGS localizadas no Sudeste e no Sul do país.

Tabela 8 - Instituições de doutoramento dos pesquisadores PQ-1A e PQ-Sr

\begin{tabular}{|c|c|}
\hline $\begin{array}{c}\text { INSTITUIÇÃO NA QUAL CURSOU } \\
\text { DOUTORADO }\end{array}$ & $\begin{array}{c}\mathrm{N}^{\circ} \mathrm{DE} \\
\text { PESQUISADORES }\end{array}$ \\
\hline PUC-SP & 9 \\
\hline USP & 9 \\
\hline PUC-Rio & 4 \\
\hline UFRGS & 4 \\
\hline Cornell University(EUA) & 3 \\
\hline UNESP & 3 \\
\hline Universityof London (Reino Unido) & 2 \\
\hline PUC-RS & 1 \\
\hline Pontifícia Università Gregoriana (Itália) & $\overline{1}$ \\
\hline Stanford University (EUA) & 1 \\
\hline UNICAMP & 1 \\
\hline UniversidadComplutense de Madrid (Espanha) & 1 \\
\hline PARIS 5, Université Paris Descartes(França) & 1 \\
\hline Universityof Glasgow(Reino Unido) & 1 \\
\hline $\begin{array}{c}\text { Total } \\
\end{array}$ & 41 \\
\hline
\end{tabular}

Fonte: banco de dados SOCED / Plataforma Lattes - CNPq, 2016. 
A grande concentração dos doutoramentos dos atuais pesquisadores num pequeno número de instituições brasileiras, e o recurso a instituições estrangeiras, sugere uma relação com a existência de poucos cursos de doutorado em Educação nas instituições no Brasil até algumas décadas atrás ${ }^{36}$.

É necessário regressar um pouco no tempo, na instituição do Parecer Newton Sucupira (Parecer $\left.n^{\circ} 977 / 65\right)^{37}$, quando a pós-graduação foi reconhecida como um novo nível de ensino. Apartir da década de 1970 começa a constituição e expansão dos cursos de mestrado e a criação dos cursos de doutorado e o ano de 1976 marca o início da consolidação da pós-graduação em Educação no país. Em 1978, ano da criação da ANPEd, a área da Educação contava com 29 programas de pós-graduação, dos quais 25 de mestrado e 4 de doutorado (FERRARO, 2005, p.51).

De acordo com Saviani (2000), os primeiros programas de doutorado em Educação foram criados entre 1976 e 1978, e são eles: os programas da PUC-Rio e UFRGS, em 1976; PUC/SP (1977) e USP (1977). A quantidade de doutoramentos nestas instituições - 9 na PUC/SP, 9 na USP, 4 na UFRGS e 4 na PUC-Rio - ressaltam a relevância de tais tanto na constituição quanto na expansão da pós-graduação em Educação. Elas formaram 26 pesquisadores da elite do campo. Isso representa bem mais da metade dos formados no país se excluirmos os 10 pesquisadores formados no exterior. Sendo, proporcionalmente, 26 de 30 pesquisadores, representam cerca de $80 \%$ dos bolsistas PQ-1A e PQ-Sr juntos. As décadas de 1970 e 1980, portanto, podem ser consideradas como marcos da expansão da pós-graduação em Educação quando verificamos o histórico do período (SAVIANI, 2000; GATTI, 2001; FERRARO, 2005).

Dentre os bolsistas PQ-1A e PQ-Sr titulados no exterior, ao todo 10, percebemos que a maioria buscou universidades européias. Podemos considerar que há uma relação entre a quantidade, ao nosso ver significativa, de pesquisadores com doutoramento no exterior e o fato da oferta de cursos de doutorado ter se expandido no Brasil somente na década de 1980. Aliado a isto,

\footnotetext{
${ }^{36}$ Para saber mais sobre o processo formativo de pesquisadores no Brasil e no exterior no início da pós-graduação no país ver Gatti (1983).

37 Parecer Newton Sucupira (Parecer n $\left.{ }^{\circ} 977 / 65\right)$ Disponível em: https://www.capes.gov.br/images/stories/download/legislacao/Parecer_CESU_977_1965.pdf.Aces so:03/04/2017
} 
houve um incentivo do governo brasileiro para doutoramento dos pesquisadores e professores de ensino superior no exterior.

Em 1975 o governo lançou o Programa de Pós-Graduação em Educação, um programa "concebido para institucionalizar o sistema na área, consolidar cursos existentes, melhorar a qualidade do ensino, aumentar a rentabilidade e controlar a expansão" (Capes, 1975, apud SANTOS e AZEVEDO, 2009 p.542). A década de 1970 caracterizou a busca pela expansão e pela consolidação dos cursos de pósgraduação em Educação e a criação da ANPEd em 1976 pode ser considerada uma grande marca deste processo de expansão.

As instituições com mais de um bolsista PQ-1A e/ou PQ-Sr titulados no exterior são UFRJ (3), UFRGS (2) e UFMG (2) ${ }^{38}$. Titulados entre as décadas de 1960 e 1990 essas três instituições foram ativas no processo de criação e de consolidação da ANPEd estando presente nas primeiras diretorias da entidade (HENRIQUES, 1998). Diante do incentivo à pesquisa e a pressão da retórica desenvolvimentista, a preocupação com o processo de expansão e "demarcação de território" via titulação e implementação da pós-graduação em suas respectivas instituições podem ter estimulado a busca de titulação no exterior para participação do processo de estruturação e funcionamento da pós-graduação em Educação no país ainda em surgimento e expansão.

Santos e Azevedo (2009) apontam para o crescimento da pós-graduação, em todas as áreas, que passou de 38 cursos em 1960 para 2588 em 2008. Em consulta aos dados sobre a pós-graduação na Plataforma Sucupira constatamos que este número dobrou, visto contarmos com 6473 cursos de pós-graduação (mestrado, doutorado e mestrado profissional) distribuídos em 4388 programas de pósgraduação. Sobre a Educação, se em 1975 haviam 17 cursos de mestrado em Educação. E se em 2008 tínhamos 128 cursos (conforme levantamento das autoras), atualmente contamos com 178 programas de pós-graduação em Educação, conforme consulta aos dados de 2017 na Plataforma Sucupira ${ }^{39}$ (CAPES/MEC).

Quando pensamos na intenacionalização e na definição de parâmetros cada vez mais exigentes com relação à inserção internacional do pesquisador pelo

\footnotetext{
${ }^{38}$ Observações e comparações das tabelas com os currículos Lattes dos pesquisadores. Acesso até 04/2017.

${ }^{39}$ Mais informações em: https://sucupira.capes.gov.br.
} 
CNPq e Capes percebemos a preocupação com o desenvolvimento científico cada vez mais globalizado. Inferimos que esse padrão de exigência pode estar relacionado ao poder de comando da elite sobre as normas e políticas de avaliação da pós-graduação e das bolsas de produtividade do CNPq.

A posse de determinados capitais constituem distinção. Os capitais em jogo no campo são armas para as lutas concorrências. A formação no exterior por si só já implica relações entre os pesquisadores e as instituições, nacionais e internacionais, produzindo oportunidades e contatos para seus membros. A proximidade com instituições estrangeiras viabiliza o atendimento da demanda de internacionalização. Conseguindo estabelecer parcerias e alcançar boa avaliação de padrão internacional, as instituições conseguem prioridade na conquista de bolsas. Trata-se de uma das estratégias de uso do poder da elite científica que se constitui pelo uso de propriedades acumuladas de vários tipos que:

“(...) são, sobretudo, objetivadas na detenção de um capital cultural de espécie particular, ou seja, aquele produzido no espaço acadêmico, em um dado período de sua história, na vanguarda de seu desenvolvimento. Mas, também, pelo capital social que é pertinente à rede de relações estabelecidas durante a trajetória de formação acadêmica e profissional, principalmente marcada por um tipo de circulação internacional.“(HEY, 2008 p.40)

Dentre os PQs-Sr, revelando o peso do pioneirismo da pós-graduação, quatro pesquisadores se titularam na PUC/SP, protagonista na pós-graduação em Educação no Brasil, e três no exterior.

Tabela 9 - Relação entre instituição atual e instituição na qual cursou o doutorado PQ-Sr

\begin{tabular}{|l|l|}
\hline \multicolumn{1}{|c|}{ INSTITUIÇÃO DO PQ-Sr } & \multicolumn{1}{c|}{$\begin{array}{c}\text { INSTITUIÇÃO NA QUAL O PQ-Sr } \\
\text { CURSOU O DOUTORADO }\end{array}$} \\
\hline 2 USP & 1 USP \\
& 1 UNESP \\
\hline 2 UFSCAR & 2 PUC/SP \\
\hline 2 UFRGS & 1 UFRGS \\
& 1 EXT. \\
\hline 1 PUC-Campinas & 1 UNESP \\
\hline 1 UFMG & 1 EXT. \\
\hline 1 UFRJ & 1 PUC/SP \\
\hline 1UNIFESP & 1 PUC/SP \\
\hline 1 UFC & 1 EXT. \\
\hline
\end{tabular}

Fonte: banco de dados SOCED / Plataforma Lattes - CNPq, 2016.

Os dados mostram que não há, quando tratamos de PQ-1A e PQ-Sr, irradiação para fora das regiões Sul e Sudeste. Formados nos primeiros programas de pós-graduação, esses pesquisadores permaneceram em instituições das próprias 
regiões Sul e Sudeste ${ }^{40}$. É curioso ressaltar que todos os PQs-Sr se formaram em instituições diferentes da que trabalham revelando um esforço de ampliação do número de programas de pós-graduação em Educação.

Entre os PQ-Sr percebemos o movimento de credenciamento e expansão da pós-graduação. Podemos considerar que há uma relação entre a quantidade de pesquisadores com doutoramento no exterior e o fato da oferta de cursos de doutorado ter se expandido no Brasil somente na década de 1980. O governo brasileiro incentivou o doutoramento dos pesquisadores e professores do ensino superior no exterior.

Entre os PQs-1A observamos o movimento de fortalecimento e enraizamento de algum modo de fazer pesquisa tendo em vista que alguns pesquisadores da USP (4) e PUC-Rio (2) se formam e permanecem na mesma instituição. Algumas instituições como a USP e a PUC/SP possuem peso na construção da tradição e um modo legitimado de fazer pesquisa. A USP formou quatro pesquisadores da própria instituição, três da UFMG e um da PUC/SP; e a PUC/SP que apesar de não ter nenhum bolsista de produtividade nessas categorias formou cinco PQ-1A e quatro PQ-Sr.

O único representante da região NE dentre "a elite da elite" (PQ-Sr) foi formado no exterior. Os investimentos desta trajetória demonstra tendência observada no campo, mas com o diferencial de estar ocupando uma universidade federal no Nordeste.

O pesquisador de origem estrangeira ainda na década de 1960 fez 3 cursos de graduação em diferentes áreas e um de seus dois cursos de mestrado, tudo no exterior. Na década de 1970 cursou Pedagogia no Rio de Janeiro, mais um curso de mestrado e o curso de doutorado na área da Educação, ambos feitos no exterior.

A coincidência da data do término do curso de doutorado em 1979 com a data de entrada na universidade federal no Nordeste podem indicar um planejamento estratégico de ocupação do lugar destinado aos pioneiros da pósgraduação no país diante da demanda de pesquisadores qualificados com formação em doutorado para instaurar os cursos stricto sensu conforme o

\footnotetext{
40 Ao tratarmos dos bolsistas Sêniors temos pesquisadores com idade científica, isto é, tempo de formação no doutorado entre 44 e 32 anos. Para saber a idade científica média de todos os bolsistas de produtividade do período analisado ver apêndice 8.2.
} 
Conselho Nacional de Pós-Graduação ${ }^{41}$ e o I Plano Nacional de Pós-Graduação (PNPG) que previa a expansão dos programas de pós-graduação em Educação e a necessidade de capacitar e qualificar os profissionais e evitar desigualdades regionais.

Tabela 10 - Relação entre instituição atual e instituição na qual cursou o doutorado PQ-1B

\begin{tabular}{|l|l|}
\hline \multicolumn{1}{|c|}{ INSTITUIÇÃO DO PQ-1B } & \multicolumn{1}{|c|}{$\begin{array}{c}\text { INSTITUIÇÃO NA QUAL O PQ-1B } \\
\text { CURSOU O DOUTORADO }\end{array}$} \\
\hline 2 UFRJ & 1 Exterior (EUA) \\
& 1 Exterior (Inglaterra) \\
\hline 3 UERJ & 1 Exterior (França) \\
& 1 UNICAMP \\
& 1 USP \\
\hline 3 USP & 1 USP \\
& 1 Exterior (França) \\
& 1 PUC/SP \\
\hline 2 UNESP & 1 UNESP \\
& 1 USP \\
\hline 2 UFBA & 2 USP \\
\hline 2 PUC-RS & 1 USP \\
& 1 UFRGS \\
\hline 2 UFMG & 1 UFMG \\
& 1 Exterior (França) \\
\hline 1 UFU & 1 USP \\
\hline 1 UFRGS & 1 UFRGS \\
\hline 1 UFPR & 1 UFPR \\
\hline 1 UFSC & 1 PUC/SP \\
\hline 1 UECE & 1 PUC/SP \\
\hline 1 UNICAMP & 1 Exterior (EUA) \\
\hline 1 UNISINOS & 1 Exterior (EUA) \\
\hline 1 UnB & 1 UNICAMP \\
\hline 1 UFSCar & 1 UNICAMP \\
\hline
\end{tabular}

Fonte: banco de dados SOCED / Plataforma Lattes - CNPq, 2016.

Dentre os 25 pesquisadores da categoria 1B, sete foram formados na USP e sete formados no exterior. A PUC/SP e a Unicamp aparecem formando três pesquisadores cada. O fato de 14 PQs-1B terem se formado em São Paulo revela o potencial simbólico do título conferido pelas notáveis instituições paulistas para entrar na dinâmica das lutas concorrenciais.

Os dados indicam o esforço de qualificação dos pesquisadores que buscaram construir capital simbólico e relacional ao cursar o doutorado nas instituições paulistas. A Unicamp formou um pesquisador da UnB, a USP, instituição com maior número de bolsistas de produtividade, formou dois PQs da UFBA e a PUC/SP formou um pesquisador da UECE. De fato, o poder do título

${ }^{41}$ O objetivo do órgão colegiado, criado em 1974, era formular políticas de pós-graduação e sua execução. 
conferido por estas instituições paulistas pode ter contribuído simbolicamente para a atual posição destes como bolsista de produtividade.

Conforme visto na tabela 10 dentre os sete pesquisadores formados no exterior, com exceção do pesquisador formado na Unisinos, repetem-se as instituições que figuram entre as principais dentre os bolsistas de produtividade, são elas UFRJ (com dois pesquisadores ), UERJ , USP, Unicamp e UFMG.

Tabela 11 - Relação entre instituição atual e instituição na qual cursou o doutorado PQ-1C

\begin{tabular}{|c|c|}
\hline INSTITUIÇÃO DO PQ-1C & $\begin{array}{c}\text { INSTITUIÇÃO NA QUAL O PQ-1C } \\
\text { CURSOU O DOUTORADO }\end{array}$ \\
\hline 7 USP & $\begin{array}{l}6 \text { USP } \\
1 \text { UNICAMP } \\
\end{array}$ \\
\hline 4 UNICAMP & $\begin{array}{l}2 \text { UNICAMP } \\
1 \text { EXT (EUA) } \\
1 \text { USP }\end{array}$ \\
\hline 4 UFRGS & 4 UFRGS \\
\hline 3 UNESP & $\begin{array}{l}2 \text { USP } \\
1 \text { UNICAMP }\end{array}$ \\
\hline 3 UFSCAR & $\begin{array}{l}2 \text { USP } \\
1 \text { UNICAMP }\end{array}$ \\
\hline $2 \mathrm{UFU}$ & $\begin{array}{l}1 \text { USP } \\
1 \mathrm{PUC} / \mathrm{SP}\end{array}$ \\
\hline 2 UERJ & $\begin{array}{l}1 \text { UFRJ } \\
1 \text { EXT.(Mex.) }\end{array}$ \\
\hline 1UFRJ & 1 EXT. (EUA) \\
\hline 1 UTP-PR & 1 UNICAMP \\
\hline 1 UNISINOS & 1 UFRGS \\
\hline 1 UFSC & 1 UNICAMP \\
\hline 1 UFMG & 1 UNICAMP \\
\hline $1 \mathrm{UFF}$ & 1 EXT (Inglaterra) \\
\hline 1 UEM-PR & 1 UNICAMP \\
\hline $1 \mathrm{UEL}$ & 1 USP \\
\hline 1 FURG & 1 UFRGS \\
\hline
\end{tabular}

Dos 34 pesquisadores da categoria 1C, quatro formaram-se no exterior e 30 foram formados em cinco instituições brasileiras: USP (13); Unicamp(9); UFRGS (6); PUC/SP (1) e UFRJ (1). Nesta categoria não há representantes de outras regiões do país, apenas do Sul e Sudeste.

Dos 13 pesquisadores 1C formados pela USP quase metade é bolsista de produtividade da própria USP (6). A UFRGS também formou 4 bolsistas de produtividade de sua própria instituição.

Entendo que o campo universitário é um lócus de relações que envolvem como protagonistas agentes que possuem a delegação para gerir e produzir práticas universitárias, isto é, uma mobilidade de produção consagrada e legitimada. É um espaço social institucionalizado, delimitado, com objetivos e finalidades específicas, onde se instala uma verdadeira luta para classificar o que pertence ou 
não a esse mundo e onde são produzidos distintos enjeux de poder. (CATANI, 2011 p.198)

As estruturas simbólicas que, no nosso caso é sugerida pela relação com a posse de títulos e de capitais simbólicos de valor legítimo no campo (publicações, participações em comissões, funções políticas no campo, etc.) indicam a violência simbólica legítima, poder, que confere -além da legitimidade- a possibilidade de exercer autoridade e gozar de prestígio (BOURDIEU, 2004).

O fato da instituição ter muitos bolsistas de produtividade formados pela própria instituição é indicador da reprodução de (uma 'violência simbólica legítima") do poder exercido pelo capital simbólico dessas instituições (Efeito Mateus). A instituição possui um título, de valor simbólico no campo, que pode servir de trunfo para espaços de publicação, eventos, comissões e até mesmo fomento para a pesquisa revertendo-se em bolsas de produtividade para os membros de tais instituições.

Tabela 12 - Relação entre instituição atual e instituição na qual cursou o doutorado PQ-1D

\begin{tabular}{|c|c|}
\hline INSTITUIÇÃO DO PQ-1D & $\begin{array}{c}\text { INSTITUIÇÃO NA QUAL O PQ-1D } \\
\text { CURSOU O DOUTORADO }\end{array}$ \\
\hline 6 UNESP & $\begin{array}{l}3 \text { USP } \\
2 \text { UNESP } \\
1 \text { UNICAMP }\end{array}$ \\
\hline 6 UERJ & $\begin{array}{l}1 \text { PUC/SP } \\
1 \text { FGV } \\
1 \text { UFRJ } \\
3 \text { EXT. (EUA, França e Argentina) }\end{array}$ \\
\hline 5 USP & $\begin{array}{l}3 \text { USP } \\
1 \text { UNESP } \\
1 \text { UNICAMP }\end{array}$ \\
\hline 5 UFMG & $\begin{array}{l}2 \text { UFMG } \\
1 \text { USP } \\
1 \text { UFRJ } \\
1 \text { EXT. (Inglaterra) }\end{array}$ \\
\hline $5 \mathrm{PUC} / \mathrm{SP}$ & $\begin{array}{l}3 \mathrm{PUC} / \mathrm{SP} \\
2 \mathrm{USP}\end{array}$ \\
\hline 4 UFSCAR & $\begin{array}{l}2 \text { USP } \\
2 \text { UNICAMP }\end{array}$ \\
\hline 3 UNISINOS & $\begin{array}{l}1 \text { PUC/SP } \\
1 \text { EST } \\
1 \text { UFRGS }\end{array}$ \\
\hline 3 UNICAMP & 3 UNICAMP \\
\hline 3 UFRN & $\begin{array}{l}2 \text { EXT. (Inglaterra e Cuba) } \\
1 \text { UFRN }\end{array}$ \\
\hline 3 UFRJ & $\begin{array}{l}2 \text { PUC-RIO } \\
1 \text { UFRJ }\end{array}$ \\
\hline 3 UFRGS & $\begin{array}{l}1 \mathrm{PUC} / \mathrm{SP} \\
1 \mathrm{PUC}-\mathrm{RS}\end{array}$ \\
\hline
\end{tabular}




\begin{tabular}{|c|c|}
\hline & 1 EXT. (Inglaterra) \\
\hline 3 UFF & $\begin{array}{l}1 \text { PUC-RIO } \\
1 \text { UFRJ } \\
1 \text { UFRJ }\end{array}$ \\
\hline 3 PUC-RS & $\begin{array}{l}2 \text { UFRGS } \\
1 \text { PUC/SP }\end{array}$ \\
\hline 2 UNIFESP & $\begin{array}{l}1 \mathrm{PUC} / \mathrm{SP} \\
1 \mathrm{USP}\end{array}$ \\
\hline $2 \mathrm{UnB}$ & $\begin{array}{l}1 \text { UFMG } \\
1 \text { EXT. (Alemanha) }\end{array}$ \\
\hline 2 UFSM & $\begin{array}{l}\text { UFSC } \\
1 \text { USP } \\
\end{array}$ \\
\hline 2 UFSC & $\begin{array}{l}1 \text { UNICAMP } \\
1 \text { PUC/SP }\end{array}$ \\
\hline 2 UFPR & 2 USP \\
\hline 2 UFPE & $\begin{array}{l}1 \text { UFF } \\
1 \text { EXT. (Espanha) }\end{array}$ \\
\hline 2 UFPB & $\begin{array}{l}1 \text { USP } \\
\text { 1UFRN }\end{array}$ \\
\hline 2 UFC & 2 EXT. (Espanha e Canadá) \\
\hline 1 UNEB & 1 UFBA \\
\hline $1 \mathrm{UFU}$ & $1 \mathrm{USP}$ \\
\hline 1 UFPEL & 1 EXT. (EUA) \\
\hline 1 UFPA & 1 EXT. (França) \\
\hline $1 \mathrm{UFJF}$ & 1 PUC-RIO \\
\hline 1 UFES & 1 UFRJ \\
\hline 1 UFBA & 1 UFBA \\
\hline 1 UFAL & 1 UNICAMP \\
\hline 1 UEPG & 1 EXT. (Inglaterra) \\
\hline 1 UEM & 1 UNESP \\
\hline $1 \mathrm{UEL}$ & 1 USP \\
\hline 1 PUC-RIO & 1 PUC-RIO \\
\hline 1 PUC-GO & 1 USP \\
\hline
\end{tabular}

Fonte: banco de dados SOCED / Plataforma Lattes - CNPq, 2016.

Os doutorados no exterior da categoria 1D são em sua maioria os bolsistas das regiões Centro-Oeste, Norte e Nordeste do país conforme podemos ver grifado na tabela 12. A maioria dos representantes destas regiões se formaram no exterior e isso pode ter proporcionado um improvement, uma acumulação de capital relacional diferenciado que contribuiu para a produção e para a internacionalização da produção conforme a demanda atual da política científica no nosso país de valorização e incentivo do CNPq para as bolsas de produtividade.

Ao retornarmos a tabela 6 e observarmos as tabelas 7, 9, 10, 11 e 12, com o local de doutoramento de cada bolsista, percebemos que há diferenças nas gerações de pesquisadores por categoria e que o aumento de bolsistas das regiões Norte e Nordeste concentrados na categoria 1D pode ter relação com a busca de 
formação no exterior e em programas interinstitucionais (Minter e Dinter) ${ }^{42}$, ambos provenientes do incentivo de agências como Capes e CNPq para tal.

Em percentuais a formação no exterior dos pesquisadores do nível PQ-1D está entre os mais baixos juntos com o nível PQ-1C. Observamos em termos de gerações que os PQ-1A e PQ-Sr buscaram formação no exterior para contribuir para o processo de implementação e desenvolvimento dos programas de pósgraduação no país. Enquanto a geração de PQ-1B, tendo a formação no exterior compõe o quadro das principais universidades do país nas regiões Sul e Sudeste.

Inferimos que a formação no exterior foi devido ao crescente incentivo no país para as pesquisas por meio das agências de fomento como também iniciação no movimento de internacionalização e aumento das relações com o exterior incentivado pelas próprias universidades e programas de pós-graduação, a fim de expandir a rede de capitais e fortalecer o potencial de pesquisa e inovação na construção do conhecimento científico.

Contudo, não podemos esquecer a ação estratégica enquanto uma das possibilidades de preencher um dos requisitos das bolsas de PQ que é a inserção internacional. O contato e a formação no exterior constitui-se diferencial para o aluno de pós-graduação, para o pesquisador e para a instituição seja de formação ou de pertença.

\footnotetext{
42 Mestrado Interinstitucional (Minter) e Doutorado Interinstitucional (Dinter) são turmas de mestrado e de doutorado conduzidas por uma instituição promotora (nacional) nas dependências de uma instituição de ensino e pesquisa receptora. As turmas estão vinculadas a programas de pósgraduação nacionais recomendados e reconhecidos recebendo fomento para a manutenção da excelência e execução do programa de formação interistitucional. A instituição promotora é responsável por garantir o nível de qualidade das atividades de ensino e pesquisa desenvolvidas por seu programa de pós-graduação na instituição receptora. Ao promover, localmente, um maior grau de qualificação dos recursos humanos, as turmas Minter e Dinter têm por objetivo principal viabilizar a formação de mestres e doutores, principalmente professores pertencentes a quadros de docentes, além de apoiar a capacitação de docentes para os diferentes níveis de ensino; subsidiar a nucleação e o fortalecimento de grupos de ensino e pesquisa; e fortalecer e estabelecer as condições para a criação de novos cursos de pós-graduação. Disponível em: http://www.capes.gov.br/avaliacao/projeto-minter-e-ou-dinter. Acesso em: 3/02/2017.
} 


\title{
4 \\ Publicações dos PQs
}

\author{
O jogo cria a illusio, o investimento no jogo do jogador \\ avisado, dotado do sentido do jogo, que habituado ao \\ jogo, pois que é feito pelo jogo, joga o jogo e, por esse \\ meio, o faz existir. \\ (BOURDIEU,1989 p.286)
}

As publicações são meio de inserção e luta por capitais dentro do jogo no campo científico. Para a Capes e o CNPq são as publicações um dos principais quesitos, dentro da produção acadêmica, para avaliar pesquisadores e programas de pós-graduação e conceder incentivos e financiamento para pesquisas.

$\mathrm{O}$ papel fundamental do $\mathrm{CNPq}$ e da Capes para o funcionamento dos programas de pós-graduação e financiamento das pesquisas científicas no país reforçam o papel do Estado como patrocinador direto das pesquisas científicas reafirmando a relevância de tais agências nas relações Estado-ciência.

Romani (1982) no artigo "O Conselho Nacional de Pesquisas e institucionalização da Pesquisa Científica no Brasil" apresenta as motivações para a criação do $\mathrm{CNPq}$ vinculada aos interesses desenvolvimentistas. Abordando a autonomia do pesquisador versus a intervenção e controle do Estado sobre a produção científica, ele assinala que o desenvolvimento da ciência e da tecnologia no Brasil sempre esteve relacionado, direta ou indiretamente, à atuação do Estado enquanto o principal financiador do desenvolvimento das instituições de ciências e tecnologia no país.

A quantidade de publicações científicas pode ser um indicativo do avanço científico e tecnológico do país contribuindo para o seu desenvolvimento. O desejo pelo desenvolvimento mobiliza políticas regulatórias do Estado pressionando os pesquisadores para aumentarem sua produção científica e buscarem inserção internacional. E se por um lado está em jogo interesses políticos maiores e exógenos ao campo, por outro há uma luta por financiamento e reconhecimento do pesquisador que almeja poder por meio da acumulação de capitais científicos.

“O capital científico enquanto capital simbólico é pautado em atos de conhecimento e de reconhecimento. O conhecer se dá de inúmeras formas, mas a principal - na atualidade - é a publicação científica.” (NASCIMENTO, 2016 
p.44) As publicações são, de fato, fonte de prestígio científico, notoriedade intelectual e poder científico.

Pierre Bourdieu (2004 p.35) define o campo científico como lugar de dois tipos de poder que correspondem a duas espécies de capital científico, (1) o poder temporal ou político, poder institucional e institucionalizado ligado a "ocupação de posições importantes nas instituições científicas"; e (2) o poder específico (capital científico "puro"), prestígio pessoal, que "repousa quase exclusivamente sobre o reconhecimento dos pares ou da fração mais consagrada dentre eles".

Essas duas espécies de capital científico têm leis de acumulação diferentes: o capital científico "puro" adquire-se, principalmente, pelas contribuições reconhecidas ao progresso da ciência, as invenções ou as descobertas; já capital científico institucional se adquire por estratégias políticas.

O capital científico "puro" traz consigo alguma coisa de carismático; o capital científico institucionalizado equipara-se a um capital burocrático. Se por um lado o capital científico "puro" visa predominar e se afirmar em termos de cientificidade e poder na área de conhecimento, o capital institucional serve para manter o poder e a força da instituição no cenário acadêmico e, por consequiência, a de seus agentes.

As publicações são como as peças principais do jogo acadêmico e criam a illusio $^{43}$ nos pesquisadores que buscam acumulação de capitais. A busca consciente por publicações revelam dinâmicas mais subjetivas do jogo.

"A illusio, que a pertença a um campo exige e produz, exclui o cinismo, e os agentes quase nunca dominam explicitamente aqueles mecanismos cujo domínio prático é a condição do seu êxito.” (BOURDIEU, 1989 p.82)

$\mathrm{Na}$ busca por salvaguardar a propriedade intelectual e divulgar os resultados de suas pesquisas científicas além dos interesses por financiamento, os pesquisadores mobilizam estratégias nem sempre conscientes em direção ao capital científico puro, na busca por reconhecimento, e ao capital científico temporal/capital político por meio de parcerias e engajamentos em comissões,

\footnotetext{
${ }^{43}$ A ilusio é um ajustamento entre as estruturas mentais do sujeito e as estruturas objetivas do campo. A illusio requer e aciona uma forma de interesse e de investimento que se expressa no reconhecimento tácito do que está em jogo. Refere-se a um campo específico, a um interesse específico e socialmente constituído que reflete-se na ideia de "estar no jogo, estar envolvido no jogo, levar a sério o jogo" (CATANI, 2017 p.231). A illusio não passa pela consciência, ela é da ordem da ação, da rotina de quem está dentro, de quem adere ao conjunto de dogmas e princípios/regras do microcosmo social em que as disputas acontecem.
} 
cargos de gestão, além da escolha de alguns temas de pesquisa em detrimento de outros.

Sobre os temas de pesquisa, concentrar-se sobre problemas considerados mais importantes pode ser fundamental para alcançar lucros simbólicos, acumulação de prestígio e de notoriedade. Cada vez mais interesses exógenos ganham importância na agenda de investigação. Nem a ciência tem conseguido fugir a lógica do "manda quem pode" diante da necessidade de verbas para a pesquisa.

As publicações têm cada vez mais sido concebidas como parâmetro internacional do desenvolvimento científico do país. Dependente do financiamento, a pesquisa no país vive a dificuldade da neutralidade e da autonomia científica diante da necessidade performativa e a forte presença dos interesses do Estado. Mesmo os pesquisadores mais reconhecidos "são obrigados a compatibilizar o tema de suas pesquisas com o tema de interesse dos órgãos de fomento à pesquisa, nem sempre atrelados às necessidades sociais" (BARBOSA, 2016, p.307)

Rodrigues (2011 p.463) ao criticar os processos de avaliação e o sistema de pontuação pelos órgãos de fomento ressalta que "o sistema de pontuação nos currículos não ajuda na construção de um sistema bem valorizado das revistas em português" que dificultam a expressividade em termos de diálogo, desenvolvimento e visibilidade científica.

França (2014) em sua tese "Avaliação da Capes e gestão de programas de excelência na área da Educação" realizou um estudo de caso com quatro instituições buscando identificar como tais instituições alcançaram a condição de programas de excelência durante o período de avaliações trienais, compreendido entre 2001 e 2010. Para análise comparativa dos discursos e práticas dos gestores de tais instituições a autora trabalhou com a teoria do campo científico de $\mathrm{P}$. Bourdieu e de performatividade de Stephen Ball revelando que a relação entre a Qualis e produtividade influenciam na dinâmica de funcionamento institucional, na constituição de estratégias locais/contextuais, na disputa pela posição de um programa de pós-graduação de excelência. Sobre este aspecto, considerando que todos os bolsistas de produtividade participam destas dinâmicas, não deixamos de ressaltar a questão performativa neste processo de "corrida" pelo volume de publicações. 
A performatividade pode ser compreendida como um mecanismo de regulação que visa por meio da competição, julgar e comparar profissionais em termos de resultados, utilizando a avaliação concorrencial e comparativa como meio de estimulação e concessão de vantagens (BALL, 2005).

As práticas performativas tendem a descaracterizar os sujeitos diante de uma racionalidade técnica. França (2014 p.121) apresenta o produtivismo como uma das maiores críticas feitas pelos coordenadores dos programas de pósgraduação com relação as políticas avaliativas alegando que "acaba gerando a replicação ${ }^{44}$ de artigos científicos ou uma falta de respeito aos diferentes tempos de pesquisa" tornando difícil determinar qual a validade da produção científica diante da oposição quantidade versus qualidade.

No âmbito educacional, a prática profissional passa a ser influenciada por regras e metas estabelecidas de modo exógeno. $O$ ensino, ação que exige interação humana, sofre um processo de objetivação de forma a ser padronizado, qualificado e comparado. Os sistemas de gestão passam a visar, prioritariamente, o desempenho, a melhoria da qualidade e a eficácia. Ball acredita que, em consequência disso, a performatividade e a mudança no perfil da gestão acabam por focar no processo de cumprimento de metas e na maximização do orçamento, por vezes, em detrimento das questões éticas, como a justiça social, a equidade e a tolerância. As mudanças são incorporadas como caminho para a excelência e há pouco debate sobre as consequências éticas das novas práticas. (FRANÇA, 2014 p.41)

Diante da lógica performativa, os pesquisadores estão buscando diversas estratégias para dar conta do "publish or perish". Preocupados com as avaliações e o acesso aos recursos e reconhecimento tem-se assistido a pressa por publicar e garantir para si a originalidade do objeto, pressa por conquistar o "nome próprio" e pressão para garantir a boa avaliação e o financiamento de suas pesquisas. Há pesquisadores que de tão preocupados e ocupados em publicar e participar da comunidade científica internacional não sabem o que está sendo produzido no seu próprio país.

O aumento da competição e a diminuição de recursos têm resultado em grave distorção cultural em que o número de publicações prevalece sobre o conhecimento, com grande sofrimento mental, menor criatividade científica, abandono da carreira e, num futuro próximo, diminuição de jovens interessados na

44 Trabalhos de Barbosa (2016), Rodrigues(2011), Leite e Neto (2017), Caregnato, Leite e Miorando (2016) e Nascimento (2016) também apontam para a dificuldade de identificar a qualidade das produções científicas diante da necessária produtividade. Sobre esse aspecto, acho importante comentarmos aqui a dificuldade que tivemos ao consultar as publicações no Currículo Lattes, pois há pesquisadores que repetem publicações, às vezes colocam o título em inglês e português (como itens diferentes) e às vezes há duplicatas da mesma publicação. Esse pode ser um dos vários limites de nossa pesquisa na construção e interpretação do universo acadêmico delimitado nesta pesquisa. 
ciência: uma combinação de fatores que pode levar ao declínio da ciência produzida no Brasil (DE MEIS et al., 2003 apud RODRIGUES,2011 p.463)

Sobre o volume da produção científica na lógica da performatividade acadêmica assiste-se ao crescente número de publicações em coautoria relacionada a diversos fatores que não apenas a alianças entre pesquisadores visando a colaboração científica para o progresso do conhecimento, mas até mesmo estratégias para aumentar o número de publicações e visibilidade no campo por meio de citações.

Diante da impossibilidade de verificar o grau de interação e de contribuição dos indivíduos nas publicações Nascimento (2016 p.72) denuncia algumas categorias de inclusão de coautores de maneira antiética como:

a) guest authors (autor/coautor convidado) utilizado para agradar superiores, utilizar-se do prestígio desse autor para facilitar a publicação do trabalho, ou ainda troca de favores (acordo de reciprocidade);

b) ghost writer (autor/coautor fantasma) inclusão de pessoas que não participaram da pesquisa, ou que preferem não ter seu nome publicado por diferentes razões (por exemplo, o pesquisador mantém vínculo formal com a empresa que patrocina o estudo).

Nascimento (2016) também comenta as estratégias de publicação, pouco cuidadosas/responsáveis, como o autoplágio e a coautoria "vazia", não supervisionada e/ou participativa com alunos bolsistas e orientandos (relatando como causas o excesso de demandas na função professor e pesquisador); as motivações performativas diante da pressão por produtividade; a construção de uma rede no campo publicando com pesquisadores de outras instituições e/ou laboratórios de pesquisa - somando capitais simbólicos e aumentando as chances do trabalho ser lido/citado - ; além da necessidade de atender em quantidade à pressão exercida aos pesquisadores pela política do "publish or perish" tão importantes para a avaliação das instituições e dos pesquisadores como já assinalado.

Apesar das duras críticas e de inferências sobre a qualidade daqueles que conseguem alcançar grande volume de publicações em curtos períodos, não podemos generalizar e questionar os méritos dos pesquisadores e a qualidade da escrita em coautoria sem um estudo minucioso que dê conta de tais publicações e da atribuição/retribuição entre colaboradores. Portanto, não sendo tal objeto desta pesquisa, mas atentos a existência de práticas estratégicas no campo científico, seguimos nossas análises considerando que coautorias diversas objetivam 
melhorar a qualidade do conteúdo publicado por meio da união de pensamentos entre os cientistas.

\section{1}

Os tipos de publicações dos PQs por níveis dentro da categoria 1 de bolsistas de produtividade do $\mathrm{CNPq}$

Sendo cada pesquisador um indivíduo construído de acordo com os capitais e os "trunfos" disponibilizados e/ou em disputa no campo, optamos por organizar as publicações por níveis (Sênior, A, B, C, D) dentro da categoria 1. Preparamos a média das produções científicas em anais, capítulos de livros, organização de livros e periódicos considerando o triênio (2013-2016) de avaliação dos bolsistas que serão apresentadas nas tabelas 13, 14, 15 e 16 respectivamente..

Nosso objetivo ao olhar para os dados por níveis foi perceber se há predominância de bolsistas em determinado "nicho" de produção científica buscando identificar correlação entre as instituições que estão no topo da hierarquia com o volume e investimento em diferentes tipos de produções científicas.

Tabela 13 - Média de publicações em anais por níveis no triênio (2013-2016)

\begin{tabular}{|c|c|c|c|}
\hline NÍVEIS & $\begin{array}{c}\mathbf{N}^{\circ} \text { DE } \\
\text { PQS }\end{array}$ & $\begin{array}{c}\text { PUBLICAÇÃO EM } \\
\text { ANAIS NO } \\
\text { TRIÊNIO }\end{array}$ & $\begin{array}{c}\text { MÉDIA DE } \\
\text { PUBLICAÇÃO EM } \\
\text { ANAIS NO TRIÊNIO }\end{array}$ \\
\hline 1A & 30 & 126 & 4,2 \\
\hline Sr & 11 & 68 & 6,18 \\
\hline 1B & 25 & 134 & 5,36 \\
\hline 1C & 34 & 318 & 9,35 \\
\hline 1D & 81 & 747 & 9,22 \\
\hline
\end{tabular}

Fonte: banco de dados SOCED / Plataforma Lattes - CNPq, 2016.

A tabela 13 demonstra que nem todos os níveis de pesquisadores investem nas publicações em anais da mesma forma que em outros veículos de divulgação científica como veremos mais adiante.

A tentativa sem sucesso de atribuir Qualis (qualificação) aos eventos ocasionou desestímulo, muitas críticas e debates em torno de quais critérios seriam válidos para atribuir distinções aos eventos definindo quais são mais representativos para o campo.

Nascimento (2016 p.118) sobre a dificuldade de estabelecer critérios para avaliar os eventos lembra

que periodicamente congressos, seminários e colóquios são criados, mas que, tal qual a "síndrome dos 3 fascículos" que acomete as revistas científicas recém 
criadas, para esses eventos o mais comum é não conseguirem se inserir na agenda científica do campo.

O campo acadêmico tem cada vez mais se submetido a regras estabelecidas, em geral pela elite empossada no campo, obedecendo muitas vezes a dinâmicas mais políticas do que acadêmicas, especialmente quando pensamos em agências de financiamentos e os interesses externos sobre o desenvolvimento científico no país.

Os eventos científicos, apesar de não ser a melhor forma de pontuar para bolsas e avaliações institucionais, ainda são uma boa oportunidade de inserção/manutenção no meio acadêmico e de aquisição de capitais sociais, políticos e científicos tanto para os recém chegados quanto para os veteranos como no caso dos PQs da categoria 1

Os eventos proporcionam contatos e parcerias com pesquisas afins, uma ótima oportunidade de ser visto, de apresentar sua pesquisa e realizar contatos com outros pesquisadores convertendo-se em capitais rentáveis no meio acadêmico-científico.

Ana Paula Hey (2008) aponta a relevância de participação em ambientes reconhecidos de produção e circulação acadêmica como parte de um ritual de instituição e de consagração de um pesquisador onde também contam a formação acadêmica e a ocupação de cargos em universidades e centros de prestígio.

Inferimos que os anais não são muito utilizados como meio de publicação pela elite científica, PQs $1 \mathrm{Ae} \mathrm{Sr}$, por serem convidados e/ou organizadores de grande parte dos eventos científicos no país, por terem seus trabalhos encomendados por revistas bem qualificadas para publicação, por não terem o hábito de publicar em eventos com orientandos e, pela dificuldade de obtenção/conhecimento do valor do evento para área e para as instâncias responsáveis por avaliar e financiar pesquisas científicas.

Durante a produção de dados observamos que, na maioria dos casos, os PQs que publicam em eventos o fazem em parceria. Talvez estes PQs publiquem com seus orientandos de pós-graduação, alunos de iniciação científica e/ou participantes do grupo de pesquisa que, em geral, são pessoas que valorizam e buscam o respaldo do nome do pesquisador já consagrado, muitas vezes coordenador de um grupo de pesquisa, para que tendo referência (teórica) do pesquisador e da instituição consiga construir e/ou fortalecer o seu nome 
individual com uma posição inicial prestigiosa no âmbito do espaço acadêmico e na área temática.

Muitos pesquisadores ao procurar determinadas instituições e determinados pesquisadores já pensam nos capitais agregados que a formação com tal pesquisador poderá lhe proporcionar. Apesar de acreditarmos nas estratégias e nas dinâmicas inconscientes do processo de "escalada" no campo científico, nós consideramos os investimentos acadêmicos dos que almejam ser pesquisador da própria instituição formativa vindo a "competir" por recursos com seus próprios formadores quando já em carreira "solo" 45 .

Observamos na tabela 13 que os pesquisadores dos níveis $1 \mathrm{C}$ e $1 \mathrm{D}$ participam com grande volume de publicações em anais de eventos nos levando a inferir a busca de contatos e acumulação de capitais sociais, políticos e científicos nos eventos científicos ou mesmo como mecanismo de mobilização de seus respectivos orientandos e membros do grupo de pesquisa (possíveis futuros pesquisadores), a habituar-se com a necessária comunicação científica proporcionando a conquista das primeiras publicações a partir da participação em eventos científicos e, em alguns casos, promovendo a vinculação do nome do pesquisador recém chegado a sua "escola"/"mentoria" de formação científica.

Os gostos ou as preferências acadêmicas são formados socialmente, ou seja, ao longo da trajetória de formação acadêmica e profissional, bem como no envolvimento com diversos ambientes sociais que constituem a vida acadêmica, tais como as instituições de produção e circulação científica. Esses gostos são materializados no produto da atividade acadêmica, como as obras, os papers, a formação de grupos de pesquisa, a participação em associações de pesquisa, entre outros. (HEY, 2008 p.104)

É importante deixar claro que apesar de estarem nos níveis mais baixos da categoria 1, tais pesquisadores já possuem distinções e capitais acumulados e são parte de uma elite acadêmico-científica não sendo questionável a capacidade técnica enquanto capital científico puro adquirido/conquistado. Portanto, tratamos aqui da necessidade de visibilidade e reconhecimento como uma forma de ultrapassarem as barreiras "invisíveis", mas perceptíveis para a mudança de níveis dentro da categoria 1. Trata-se de pensar o quanto essa produção em anais de eventos é também forma de mobilizar capital social e político que pode ser

\footnotetext{
${ }^{45}$ De certo, não há carreira solo em pesquisa científica, mas utilizamos "carreira solo" no sentido de construção de um grupo de pesquisa próprio independente das parcerias que podem se estabelecer. Aliás, não existe pesquisa científica solitária.
} 
convertido em outras formas de capitais tanto para a manutenção quanto para conquista de níveis mais elevados dentro da categoria 1.

Tabela 14- Média de capítulos de livro por níveis no triênio (2013-2016)

\begin{tabular}{|c|c|c|c|}
\hline NÍVEIS & $\begin{array}{l}\mathbf{N}^{\mathbf{0}} \text { DE } \\
\text { PQS }\end{array}$ & $\begin{array}{l}\text { CAPÍTULOS DE } \\
\text { LIVRO NO } \\
\text { TRIÊNIO }\end{array}$ & $\begin{array}{l}\text { MÉDIA DE } \\
\text { CAPÍTULOS DE } \\
\text { LIVRO NO TRIÊNIO }\end{array}$ \\
\hline 1A & 30 & 362 & 12,06 \\
\hline $\mathrm{Sr}$ & 11 & 73 & 6,63 \\
\hline 1B & 25 & 255 & 10,2 \\
\hline 1C & 34 & 263 & 7,73 \\
\hline 1D & 81 & 758 & 9,35 \\
\hline
\end{tabular}

Fonte: banco de dados SOCED / Plataforma Lattes - CNPq, 2016.

Os pesquisadores consagrados são os mais autorizados a impor a legitimidade de temas e agenda de pesquisa para a área. E isso pode ser inferido em nossos dados se observarmos que os pesquisadores que mais produzem capítulos para livros são o extrato mais alto da elite acadêmica, os PQs-1A. Cientistas reconhecidos, pertencentes a instituições renomadas, como no caso dos

PQs 1A, acabam tendo mais facilidade de publicar seus trabalhos considerados relevantes para a ciência. Bourdieu (2014, p.83-84) abordando sobre a antiguidade na profissão e herança profissional enquanto diferenciais afirma que:

Há a importância diferencial da antiguidade na profissão, pois estes "possuem uma vantagem considerável na competência porque têm, no mais alto grau, certas propriedades exigidas, explícita ou tacitamente, aos recém ingressados: em primeiro lugar, o capital simbólico associado a um nome próprio_e de espécie tal que assegure, a maneira de uma marca famosa no caso das empresas, uma relação durável com uma clientela adquirida de antemão; e em segundo lugar, o capital cultural específico cuja possessão constitui sem dúvida um trunfo tanto mais poderosa quanto menos objetivado, formalizado é este capital em vigor no campo em questão (...). (Negritos nossos)

O "nome próprio" conquistado pelos pesquisadores atraem instituições que gostariam de desfrutar do prestígio de tais PQs para alavancar seus programas de pós-graduação e conquistar financiamentos para seus grupos de pesquisa. Assim, muitas vezes os pesquisadores que organizam eventos e publicações querem agregar seu nome aos eventos e as revistas científicas com o respaldo do "nome próprio" de um pesquisador consagrado como os pertencentes a categoria 1 do CNPq.

$\mathrm{Na}$ arena de lutas científicas, o prestígio de uma instituição/ de um pesquisador pode constituir-se em diferencial para a conquista de capitais e recursos burocráticos com fins científicos (HEY, 2008). 
Por possuírem o trunfo do "nome próprio", o prestígio que os distingue, os pesquisadores da categoria 1, em especial dos níveis $1 \mathrm{~A}$ e $\mathrm{Sr}$, reconhecem o valor de suas participações científicas e o empregam, na maioria das vezes, visando a conversão de outras espécies de capitais agregadas ao nome construído e expertise.

Hey (2008) relembra o uso de Bourdieu sobre a conquista do "nome próprio" ressaltando que alguns pesquisadores já consagrados no campo universitário são bastante cautelosos na participação/inserção de seu nome em publicações e/ou mesmo na instituição de parcerias com outros laboratórios de pesquisa por não lhes apresentarem vantagens no sentido da realização do nome. Pelo contrário, a vinculação/ o empréstimo do nome de tais pesquisadores poderiam impulsionar capitais e a notoriedade de outros pesquisadores de temas afins não sendo, portanto, interessante para a manutenção de suas posições conquistadas. "A razão principal é que o nome construído individualmente origina maiores ganhos simbólicos e, ao mesmo tempo, sua posição já está demarcada no universo acadêmico.” (HEY, 2008 p.114)

Apesar da produção reduzida, os pesquisadores Sêniors podem ter diversas motivações para não estar investindo em livros. Dentre elas, a lentidão do processo para a produção de um livro e os convites para publicações em revistas mesmo que, ainda não bem qualificadas, para impulsioná-las no meio acadêmico, conforme o gráfico 1 que apresentaremos mais adiante.

Os PQs-Sr obedecem a mesma lógica de produtividade de todos, mas com a "leveza" de serem consagrados e detentores de capitais almejados por muitos do campo. Eles podem estar "se aposentando" e dando espaço para o surgimento de novos pesquisadores.

Percebemos nas nossas análises a força dos pesquisadores $1 \mathrm{~A}$ com uma publicação média de 12 capítulos seguido dos PQs-1B com média de 10 capítulos e 1D com a média de 9 capítulos de livros.

Considero que a alta média dos PQs-1B e 1D são indicadores da luta dos pesquisadores de tais níveis na concorrência por melhores posições e/ou mesmo o não rebaixamento. No caso dos PQs-1B a estratégia pode indicar a força para ascender a posição mais prestigiosa de PQ-1A e/ou o não rebaixamento para PQ1C. Do mesmo modo que os PQs-1D pensam em estratégias para ascender a posições superiores evitando ao máximo a queda para o nível 2. 
Tabela 15 - Média de livros organizados por níveis no triênio (2013-2016)

\begin{tabular}{|c|c|c|c|}
\hline NÍVEIS & $\begin{array}{c}\mathbf{N}^{\mathbf{0}} \text { DE } \\
\text { PQS }\end{array}$ & $\begin{array}{c}\text { LIVROS } \\
\text { ORGANIZADOS } \\
\text { NO TRIÊNIO }\end{array}$ & $\begin{array}{c}\text { MÉDIA DE LIVROS } \\
\text { ORGANIZADOS NO } \\
\text { TRIÊNIO }\end{array}$ \\
\hline 1A & 30 & 133 & 4,43 \\
\hline $\mathrm{Sr}$ & 11 & 24 & 2,18 \\
\hline 1B & 25 & 72 & 2,88 \\
\hline 1C & 34 & 122 & 3,58 \\
\hline 1D & 81 & 282 & 3,48 \\
\hline
\end{tabular}

Fonte: banco de dados SOCED / Plataforma Lattes - CNPq, 2016.

Os livros no meio acadêmico da área da Educação são um importante meio de divulgação científica, pois as Ciências Humanas conferiram ao livro, ao longo de sua institucionalização, uma maior importância informativa e formativa.

A pesquisa de Nascimento (2016) denuncia o alto custo da produção de livros além da "incipiência" (nas palavras da autora) da tabela de classificação Qualis/Livros/ Coletâneas e Eventos. Numa pesquisa longitudinal entre 1990 e 2015, a pesquisadora mostra que, embora os livros ainda sejam produzidos em quantidade considerável, há cada vez mais a preferência por publicações em periódicos. $^{46}$

Observamos que os PQs-1A são os que mais publicam capítulos em livros e organizam publicações devido ao peso do valor simbólico destes pesquisadores. Os pesquisadores mais consagrados, talvez por não terem necessariamente que entrar na lógica do publicar ou morrer, acabam tendo tempo e espaço acadêmico para organização e publicação de mais livros. Além disso, por estarem no topo da hierarquia é possível que as verbas para arcar com o alto custo da publicação de livros cheguem com mais facilidade a esses pesquisadores.

Considerando a necessidade de relações políticas no campo, as coletâneas com diversos autores do grupo de pesquisa ou de outras equipes, organizados por um pesquisador de renome é uma forma de desenvolver parcerias e alianças caracterizando afinidades e autorizando a fala científica de alguns em detrimento a outros.

O esquema de colaboração científica tem, dentre tantas funções, a de aumentar a oxigenação do campo mediante a entrada de novos coautores, empossados ou não de algum grau de distinção, mas que pela tarefa desenvolvida (escrita em colaboração) surge na rede como nó pendente (aquele que fica no extremo das redes gerais), mas que são os responsáveis pela entrada de novas teorias e aumento da possibilidade de criação de novos colégios invisíveis. (NASCIMENTO, 2016 p.155)

${ }^{46}$ Ver Nascimento (2016). 
A produção científica em coletâneas com outros pesquisadores pode aumentar a chance do trabalho ser citado trazendo vantagens tanto para os indivíduos quanto para as instituições em virtude do fortalecimento de uma rede de fazer científico que quando articulada fortalecem o campo.

"A inter-relação dos pesquisadores entre si e de forma individual com os grupos constituídos pode ser evidenciada, ainda, pela produção de livros na forma de coletâneas." (HEY, 2008 p.113)

De certo, ser pesquisador 1A e estar no topo da hierarquia é caracterizador de poder e experiência no campo, por isso a facilidade de circulação dos PQs-1A e financiamentos para pesquisas e divulgação científica como a organização de livros tratada neste tópico.

Por meio das trocas simbólicas operadas por uma valoração interna dos agentes inscritos no campo seja pela quantidade de livros organizados seja pela notoriedade de suas instituições (tanto de pertencimento quanto de doutoramento), estes pesquisadores acabam agregando ainda mais capitais, especialmente, na publicação de livros que, como mencionado anteriormente, desempenha não só papel na divulgação científica, mas também de "legado" para o campo da Educação. O livro é utilizado muitas vezes como canal formativo para as próximas gerações de educadores que o referendarão no seu percurso acadêmico e consagrarão pesquisadores e instituições enquanto bases sólidas de conhecimento científico.

Os pesquisadores dos níveis 1C e 1D também demonstram características do grande investimento para manter posições e ascender. É possível relacionarmos este investimento na divulgação científica como uma forma de manutenção de posições submetendo-se a lógica do publicar ou morrer. São pesquisadores que já entraram no jogo alinhados as regras vigentes buscando acumular seus capitais no campo.

Todas as vezes que observamos esse volume médio de publicações (em todas as categorias de publicações aqui apresentadas) estamos ratificando a capacidade dos pesquisadores produzirem grandes quantidades em curto espaço de tempo. No entanto, a questão da qualidade ainda é questão posta para a área diante tanto do volume quanto das subjetividades inscritas na avaliação. 
Tabela 16 - Média de publicações em periódicos por níveis no triênio (20132016)

\begin{tabular}{|c|c|c|c|}
\hline NÍVEIS & $\begin{array}{c}\mathbf{N}^{\mathbf{0}} \text { DE } \\
\text { PQS }\end{array}$ & $\begin{array}{c}\text { PUBLICAÇÕES } \\
\text { EM PERIÓDICOS } \\
\text { NO TRIÊNIO }\end{array}$ & $\begin{array}{c}\text { MÉDIA DE } \\
\text { PUBLICAÇÕES EM } \\
\text { PERIÓDICOS NO } \\
\text { TRIÊNIO }\end{array}$ \\
\hline 1A & 30 & 352 & 11,73 \\
\hline $\mathrm{Sr}$ & 11 & 103 & 9,36 \\
\hline 1B & 25 & 334 & 13,36 \\
\hline 1C & 34 & 518 & 15,23 \\
\hline 1D & 81 & 1150 & 14,19 \\
\hline
\end{tabular}

Fonte: banco de dados SOCED / Plataforma Lattes - CNPq, 2016.

Observando o volume médio de publicações por níveis inferimos que, por estarem no final da carreira, os pesquisadores Sêniors não sentem tanta necessidade de obedecer a dinâmica performativa da produtividade apresentando a publicação média de 9 artigos por triênio. Consideramos um número razoável, mas dentro do quadro performativo que se apresenta essa produção pode refletir a "saída de cena" desses pesquisadores que já se consagraram no campo com suas contribuições científicas.

A autoridade, o prestígio e os capitais acumulados os dão a possibilidade de escolha de onde, o que e quando publicar. Percebemos na produção dos PQs-Sr e dos PQs-1A um parâmetro razoável de publicação, dois ou três artigos por ano durante o triênio (2013-2016). A estabilidade da posição no meio acadêmicocientífico pode ter se constituído como fundamental para a "saudável" produção acadêmica.

O poder institucional representado pelas posições dos agentes são mecanismos para mobilizar recursos próprios da atividade científica assim como recursos extracientíficos para a manutenção do poder.

Na tabela 16 a elevada produção de artigos por pesquisadores dos níveis $1 \mathrm{C}$ e $1 \mathrm{D}$, com a média de 15 e 14 artigos, respectivamente, caracterizam estratégias performativas para a conquista do volume de produções visto que a gestão entre o trabalho de pesquisador e professor na pós-graduação soma-se a necessidade de publicações e divulgação dos processos e resultados de pesquisa.

$\mathrm{O}$ alto número de publicações por pesquisador no triênio nos leva a inferir que a dinâmica/volume de publicações em periódicos parece obedecer mais a uma lógica das avaliações da Capes e do $\mathrm{CNPq}$ do que propriamente o fluxo de resultados em relação ao investimento em pesquisas científicas. 
Os pesquisadores 1C possuem em média 15 publicações, o maior número de publicações entre todos os níveis sendo um interessante indicador da contenção da mobilidade para níveis superiores e do receio do rebaixamento. Estariam sendo "barrados" pelas regras de concessão e avaliação dos bolsistas pelos CAs (formados pelos próprios pares) ou estariam sendo vítimas dos "guardiões dos limites do grupo", do qual nos fala Bourdieu, em Coisas Ditas (2011)?

Os PQs reconhecidos na posição de elite científica no campo (os detentores do "nome próprio") acabam sendo os verdadeiros "guardiões dos limites do grupo", sendo responsáveis pela manutenção do campo e a definição da legitimidade das práticas de entrada, de permanência e de exclusão no jogo.

A posição de cada agente nessa estrutura, ou melhor, o peso de cada um para formar essa estrutura e ao mesmo tempo suportá-la, depende de todos os outros pesquisadores, bem como de todos os pontos do espaço e das relações entre todos os pontos. Cada ponto é equivalente a uma posição, sendo que aquela ocupada pelo pesquisador vai restringir ou aumentar o campo dos possíveis que lhe é aberto. (HEY, 2008 p.80)

Sobre essa relação entre posições e o "campo dos possíveis" percebemos que os PQs-1C e PQs-1D possuem volume de publicações indicador da força de tais níveis no que se refere a divulgação científica. Esta força caracteriza a mobilização estratégica dos agentes para acumular capitais via publicações almenjando níveis mais elevados dentro da categoria 1 e as vantagens que tais posições trazem consigo. Mas o que retém para tais níveis a possibilidade de uma mobilidade ascendente? Por que não conseguem níveis mais elevados diante da produção apresentada? Aliás, a produção dos PQs 1C e 1D é maior do que a dos PQs do nível 1B, 1A e Sr. De fato,

o sistema de comunicação científica chancela e confere distinção aos autores que dele fazem parte, atribuindo-lhes maior capital científico puro, que poderá ser transformado em temporal conforme os postulados de Pierre Bourdieu. Essa distinção, feita não só com base em temáticas e teorias, mas também nas regras instituídas e compartilhadas, define aqueles que compõem o campo, mas principalmente, aqueles que se destacam no campo (elite científica). (NASCIMENTO, 2016, p.66)

Rodrigues (2011 p.459), em artigo sobre financiamento para a produção científica na área dos esportes criticas os critério de seleção de projetos pelas agências de fomento do país visto que "o perfil do solicitante é levado mais em conta do que a pesquisa em si gerando distorções na hora da escolha, pois a 
decisão se baseia no número de trabalhos publicados e na qualidade dos periódicos científicos que os aceitaram" (grifos nosso).

Embora o volume não seja caracterizador da qualidade da produção científica exigida pelo CA do CNPq, há sempre questões subjetivas que envolvem as avaliações. Nascimento (2016) analisa a problemática da avaliação da produção acadêmica no país com relação aos critérios que "garantiriam" a qualidade do que se produz e se publica além da forma como esses critérios (geralmente disponíveis na seção de "orientações ao autor" dos periódicos) são empregados nos diferentes níveis exigidos pela comunicação científica constatando um jogo de polissemia. Tais critérios dão grande margem interpretativa aos pesquisadores dificultando a avaliação livre de subjetividades.

Optamos por caracterizar as produções de cada pesquisador totalizando a consulta de 2457 publicações, ressaltando que estamos voltados para as relações entre a bolsa de produtividade e instituições e não propriamente agentes. Mas, diante das publicações de cada agente e o poder das instituições é impossível não nos atentarmos para uma possível barreira existente entre os níveis nas quais subjetividades e estratégias entre pesquisadores e instituições estejam presentes, mesmo que não seja racionalizado pela maioria.

Até que ponto a avaliação para a concessão de bolsa é neutra? Observamos que há fronteiras difíceis de serem transpostas para os pesquisadores dos níveis 1B, 1C e 1D apesar da força via produção científica para ultrapassá-las. Isso nos leva a pensar nas relações institucionais na produção de capitais dentre as disposições e/ou estratégias postas em ação para a acumulação de capitais rentáveis para adquirir posições e vantagens no jogo do campo científico.

O capital simbólico, agregado ao valor simbólico da instituição de pertencimento, pode ser elemento de diferenciação e/ou distinção como por exemplo, a credibilidade para publicar em revistas mais bem qualificadas, ser convidado para participar de instâncias de decisão na área da Educação, que constituindo uma rede, pode impulsionar ao pleito de posições privilegiada junto com a elite acadêmica.

Nos questionamos se há subjetividade na avaliação da produção para além da WebQualis? Quais capitais estão sendo contabilizados e/ou rentabilizados nessas avaliações? Será que há relação entre as publicações e as instituições que 
estão no topo da hierarquia de acordo com o volume das publicações nas revistas A1, A2 e B1 avaliadas para a concessão de bolsas?

Essas são algumas indagações que tentaremos desenvolver nas seções seguintes observando o volume de publicações em periódicos por instituição, os periódicos que mais recebem publicação dos bolsistas de produtividade ${ }^{47}$ e os periódicos mais bem qualificados pelo Web Qualis usados pelos pesquisadores na divulgação científica.

\section{2}

\section{Publicações dos PQs em periódicos Qualis A1, A2 e B1}

Trabalharemos neste item com as publicações em periódicos por concentrarem o maior volume de publicações e também pela relevância dos periódicos para a avaliação dos programas institucionais e concessão de bolsas.

A tabela 17 com o volume total de publicações no triênio (2013-2016) indica que os artigos em periódicos são a principal fonte de produção científica no momento.

A presença dos capítulos de livros com o segundo maior volume sugere a construção de parcerias e convites para publicar trazendo credibilidade e oportunizando a outros pesquisadores participação nos livros bastante relevantes para a área.

Tabela 17 - Volume total de publicações no triênio (2013-2016) de acordo com o tipo de publicação

\begin{tabular}{|l|c|c|c|c|c|c|}
\hline \multirow{2}{*}{ TIPO DE PUBLICAÇ̃̃O } & \multicolumn{5}{|c|}{ NÍVEIS } & \multirow{2}{*}{ TOTAL } \\
\cline { 2 - 6 } & 1A & Sr & 1B & 1C & 1D & \\
\hline $\begin{array}{l}\text { ARTIGO EM } \\
\text { PERIÓDICOS }\end{array}$ & 352 & 103 & 334 & 518 & 1150 & 2457 \\
\hline $\begin{array}{l}\text { CAPÍTULOS DE } \\
\text { LIVROS }\end{array}$ & 362 & 73 & 255 & 263 & 758 & 1711 \\
\hline ARTIGO EM ANAIS & 126 & 68 & 134 & 318 & 747 & 1393 \\
\hline $\begin{array}{l}\text { LIVROS } \\
\text { ORGANIZADOS }\end{array}$ & 133 & 24 & 72 & 122 & 282 & 633 \\
\hline
\end{tabular}

Fonte: banco de dados SOCED / Plataforma Lattes - CNPq, 2016.

\footnotetext{
47 Sobre os periódicos que mais recebem publicação dos bolsistas de produtividade, elegemos apresentar dados dos extratos que até então são avaliados para a concessão de bolsas são eles: A1, A2 e B1.
} 
Os critérios de concessão de bolsas de produtividade prevêem para todas as categorias e níveis um número de publicações em periódicos qualificados com Qualis A1, A2 e B1 caracterizador da produção de "excelência" conforme podemos ver no quadro 6 .

\begin{tabular}{|c|c|c|c|c|}
\hline PQ 1 $1^{a}$ & PQ Sr & PO 1B & PO 1C & PO 1D \\
\hline $\begin{array}{lr}\text { O Pesquisador } \\
\text { deve } & \text { exceder } \\
\text { todos } & \text { os } \\
\text { requisitos } & \\
\text { aplicados } & \text { aos } \\
\text { níveis B, C e } & \text { D, } \\
\text { expressar } & \\
\text { liderança } \\
\text { acadêmico- } \\
\text { científica na Área } \\
\text { no país e no } \\
\text { exterior e ser } \\
\text { capaz de explorar } \\
\text { novas fronteiras } \\
\text { científicas em } \\
\text { projetos de risco, } \\
\text { manifestando } \\
\text { regularidade na } \\
\text { produção } \\
\text { acadêmica } \\
\text { formação } \\
\text { recursos } \\
\text { humanos. }\end{array}$ & $\begin{array}{l}\text { Considerados } \\
\text { como referências } \\
\text { na Área, em razão } \\
\text { de sua } \\
\text { significativa } \\
\text { contribuição para } \\
\text { a pesquisa e } \\
\text { formação de } \\
\text { recursos humanos } \\
\text { em Educação, } \\
\text { com trajetória de } \\
\text { reconhecida } \\
\text { distinção } \\
\text { acadêmica, } \\
\text { Pesquisador } 1 \text { A } \\
\text { e/ou 1B, após 15 } \\
\text { anos nesses níveis } \\
\text { no sistema, está } \\
\text { habilitado } \\
\text { categoria à } \\
\text { Pesquisador } \\
\text { Sênior. }\end{array}$ & 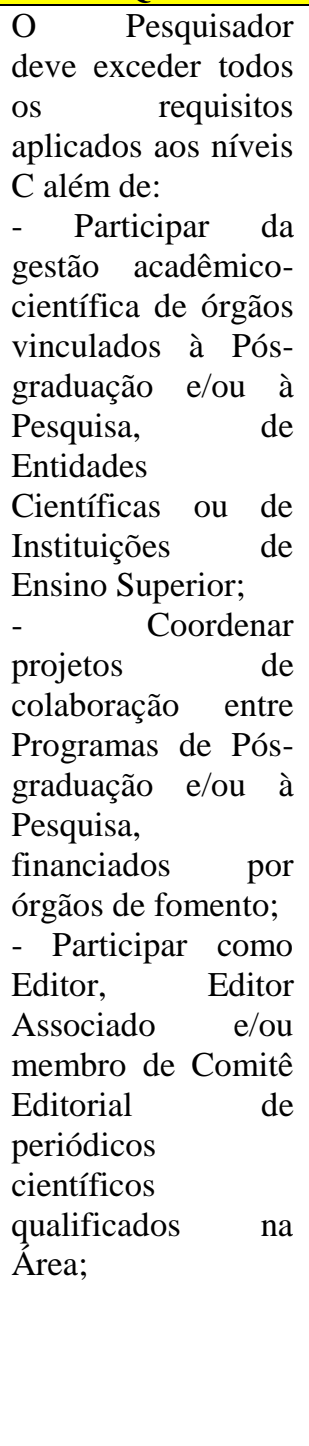 & 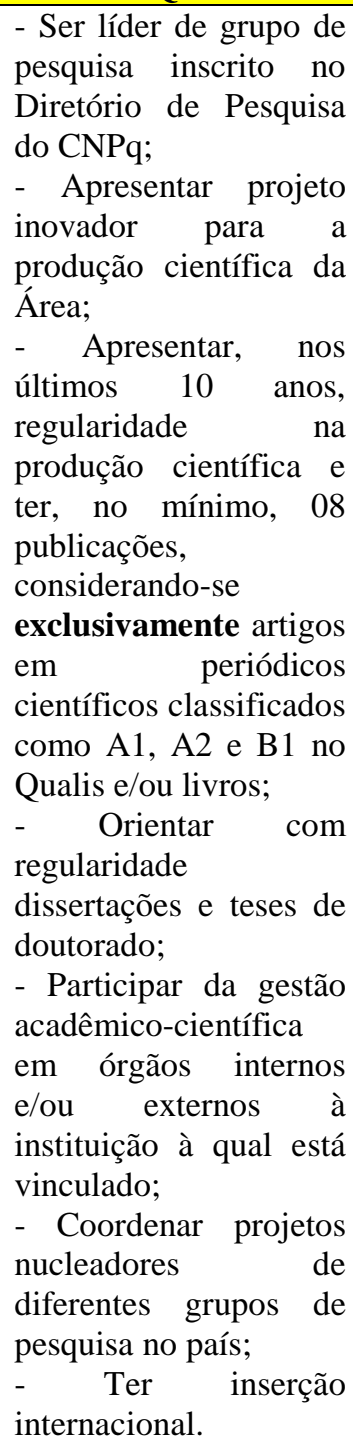 & $\begin{array}{l}\text { - Estar vinculado a } \\
\text { grupo de pesquisa } \\
\text { registrado no } \\
\text { Diretório de Pesquisa } \\
\text { do CNPq; } \\
\text { - Apresentar, nos } \\
\text { últimos 10 anos } \\
\text { regularidade na } \\
\text { produção científica e } \\
\text { ter, no mínimo, 06 } \\
\text { publicações, } \\
\text { considerando-se } \\
\text { exclusivamente } \\
\text { artigos em periódicos } \\
\text { científicos } \\
\text { classificados como } \\
\text { A1, A2 e B1 no } \\
\text { Qualis e/ou livros; } \\
\text { - Estar vinculado a } \\
\text { um Programa de Pós- } \\
\text { graduação e já ter } \\
\text { conclúdo } \\
\text { orientação de pelo } \\
\text { menos 01 aluno de } \\
\text { doutorado ou 04 } \\
\text { alunos de mestrado se } \\
\text { o Programa não tiver } \\
\text { doutorado (ou se tiver } \\
\text { sido criado há menos } \\
\text { de 06 anos); }\end{array}$ \\
\hline
\end{tabular}

Fonte: site do CNPq

No entanto, para todos os itens especificados é definido pelo CNPq que "em casos especiais, o CA-Ed poderá considerar exceções mediante justificativas bem fundamentadas". Quais seriam as exceções? Num edital semelhante a um concurso público quais seriam as justificativas válidas a serem consideradas como exceção? De certo, a avaliação pelos pares pode ser um recurso eficiente na disputa para impor a definição legítima de pesquisa. Nascimento (2016 p.45) 
assinala subjetividades inscritas no texto do edital das bolsas de produtividade do CNPq afirmando que "não há julgamentos isentos de certa subjetividade perniciosa".

A avaliação pelos pares traz como benefício maior compreensão do objeto e dos processos de produção de ciência pelos companheiros da área, mas por outro lado revela a difículdade de avaliação por conta dos "julgamentos contaminados" (NASCIMENTO, 2016).

A "avaliação comparativa" proposta - muitas vezes com forte carga subjetiva - reproduzem a consagração de alguns já que a concorrência/competição entre os cientistas é o principal gerador de desequilíbrio diante de qualquer regra explícita.

A variação de volume de publicações de acordo com cada nível traz a exigência mínima de 6 publicações, exclusivamente artigos em periódicos científicos classificados como A1, A2 e B1 no Qualis e/ou livros para inserir-se no nível 1D, sendo crescente a exigência conforme o nível pleiteado pelo pesquisador.

Escolhemos utilizar como parâmetro o triênio no qual foi concedida a bolsa de produtividade (2013-2016) para olharmos relacionalmente o maior volume de artigos para periódicos A1, A2 e B1 no período. Consideramos ser essa uma medida razoável para lidarmos com as instituições já que não tratamos de mudanças de pertencimento institucionais neste curto período analisado.

A publicação científica é moeda de troca dentro da comunidade científica e não apenas um meio de produção e divulgação de conhecimento. Portanto, resolvemos apresentar os periódicos que mais recebem publicações pelos bolsistas de produtividade e são avaliados pelo CNPq para a concessão da bolsa de produtividade: os extratos A1, A2 e B1 mostrando também as instituições de pertença de tais periódicos. Visamos observar se há relação cíclica entre as posições ocupadas e a detenção de legitimidade seja no meio institucional, seja no monopólio dos meios de divulgação científica que geram benefícios/solidariedades institucionais no que diz respeito a avaliação pelos pares que podem conceder maiores chances de aprovação de artigos ou mesmo melhor avaliação em relação aos pares/ demais pesquisadores da área.

Para eleger o coorte realizamos a tabulação de recorrências constatando que a média de publicações em uma mesma revista variavam de 1 a 7 artigos, portanto 
destacamos em nossas tabulações o quantitativo que ultrapassava essa margem, conforme será visto nas tabelas 18,19 e 20.

A instituição confere capital simbólico de valor institucionalizado. Apesar do peso relativo, a titulação pode constituir-se em uma violência simbólica legítima que pode ser convertida em moeda de troca no campo, visto que “(...) não é o valor relativo do trabalho que determina o valor do nome, mas o valor institucionalizado do título que serve de instrumento o qual permite que se defenda e se mantenha o valor do trabalho.” (BOURDIEU, 1989 p.148)

Tabela 18- Periódicos A1 com maior número de contribuições dos PQ

\begin{tabular}{|c|c|c|}
\hline NOME DO PERIÓDICO A1 & $\begin{array}{l}\text { QUANTIDADE } \\
\text { DE } \\
\text { PUBLICAÇÕES }\end{array}$ & $\begin{array}{c}\text { INSTITUIÇÃO } \\
\text { DO } \\
\text { PERIÓDICO }\end{array}$ \\
\hline Enseñanza de las Ciencias & 42 & $\begin{array}{l}\text { Universidade de } \\
\text { Vigo/Espanha }\end{array}$ \\
\hline $\begin{array}{l}\text { Educação e Pesquisa - Revista da Faculdade de } \\
\text { Educação da USP }\end{array}$ & 32 & USP \\
\hline História da Educação & 30 & UFPel \\
\hline Revista Brasileira de Educação & 29 & ANPEd \\
\hline Ciência e Educação & 28 & UNESP \\
\hline Educação e Realidade & 23 & UFRGS \\
\hline Educação \& Sociedade & 22 & Unicamp \\
\hline Cadernos de Pesquisa & 22 & $\begin{array}{l}\text { FCC (Fundação } \\
\text { Carlos Chagas) }\end{array}$ \\
\hline Educar em Revista & 20 & UFPR \\
\hline $\begin{array}{l}\text { Archivos Analíticos de Políticas Educativas / } \\
\text { Education Policy Analysis Archives }\end{array}$ & 18 & $\begin{array}{l}\text { College of } \\
\text { Education } \\
\text { University of South } \\
\text { Florida/EUA }\end{array}$ \\
\hline Educação em Revista & 18 & UFMG \\
\hline Pró-Posições & 16 & Unicamp \\
\hline Revista Brasileira de História da Educação & 16 & $\begin{array}{l}\text { SBHE (Sociedade } \\
\text { Brasileira de } \\
\text { História da } \\
\text { Educação) }\end{array}$ \\
\hline $\begin{array}{l}\text { Avaliação: Revista da Avaliação da Educação } \\
\text { Superior }\end{array}$ & 15 & Unicamp \\
\hline Educação (UFSM) & 14 & UFSM \\
\hline Boletim de Educação Matemática & 12 & UNESP \\
\hline
\end{tabular}

Fonte: banco de dados SOCED / Plataforma Lattes - CNPq, 2016.

A legitimidade das principais instituições de nossa hierarquia institucional está bem representada na tabela 18. Apesar da existência de 121 periódicos nesta categoria há concentração de publicações em apenas 16, sendo dois internacionais. A força das instituições paulistas está caracterizada pela presença de um periódico da USP, dois da UNESP e três da Unicamp. As instituições do 
campo do poder da hierarquia que elaboramos entre os PQs também estão ali representadas pela USP, UFMG e UFRGS.

Ao estabelecer critérios que visam potencializar a qualidade dos trabalhos publicados, a elite cria um halo em torno das melhores revistas científicas, dos melhores eventos e, agora, dos melhores livros. Toda essa mecânica contribui para a manutenção dos mesmos agentes nas posições de destaque. Importante salientar que quando se diz "mesmos", está-se referindo ao mesmo perfil e não, necessariamente, ao mesmo indivíduo.(NASCIMENTO E BUFREM, 2016, p. 15)

Percebemos também a força de entidades como a ANPEd e a Fundação Carlos Chagas, como um dos principais veículos de divulgação do extrato A1 utilizado pelos cientistas, reafirmando o poder das entidades para a manutenção do poder de regulação da cientificidade da área. Assim como uma disputa em veículos de publicação internacional como as dos periódicos: Enseñanza de las Ciencias e Archivos Analíticos de Políticas Educativas/Education Policy Analysis Archives que representam mais do que a disputa por internacionalização, uma disputa por visibilidade nos mesmos veículos internacionais.

A comunidade científica é um espaço de concorrência e não só de produção de conhecimento. Entendendo a dinâmica de "adversários cúmplices"48, a publicação dos pesquisadores visa consagração de seu valor e reconhecimento da qualidade dos produtos científicos desenvolvidos diante da comunidade, aumentando o poder científico puro e buscando acumulação de outras espécies de capitais como sociais e políticos.

Ao observarmos a tabela 19 veremos o forte papel das revistas de determinadas áreas - como as da UFMG que são da área do ensino de Ciências - e das associações e entidades de pesquisa para reconhecimento e validação científica do PQ e sua pesquisa.

As publicações desempenham no campo funções específicas nos processos de avaliação e "autorização cientifica" de ordem simbólica (mediada pelos pares da área) e é inegável que todas as relações entre os agentes e as instituições são "mediadas pela estrutura do sistema das relações entre as instâncias com pretensões a exercer uma autoridade propriamente cultural”. (BOURDIEU, 2007, p.118)

\footnotetext{
${ }^{48}$ No campo científico o seu maior concorrente, o maior oponente, pode ser também o seu maior colaborador na busca pela obtenção e acúmulo de capitais (científico, político e social) (BOURDIEU, 2005).
} 
Tabela 19 - Periódicos A2 com maior número de contribuições dos PQs

\begin{tabular}{|c|c|c|}
\hline NOME DO PERIÓDICO A2 & $\begin{array}{l}\text { QUANTIDADE } \\
\text { DE } \\
\text { PUBLICAÇÕES }\end{array}$ & $\begin{array}{c}\text { INSTITUIÇÃO } \\
\text { DO } \\
\text { PERIÓDICO }\end{array}$ \\
\hline Revista e-Curriculum (PUCSP) & 31 & PUC/SP \\
\hline $\begin{array}{l}\text { Revista Brasileira de Pesquisa em Educação em } \\
\text { Ciências }\end{array}$ & 30 & UFMG \\
\hline Ensaio: Pesquisa em Educação em Ciências & 26 & UFMG \\
\hline Currículo sem Fronteiras & 24 & $\begin{array}{l}\text { Conselho Editorial } \\
\text { Internacional, } \\
\text { constituído por } \\
\text { investigadores de } \\
\text { diferentes instituições } \\
\end{array}$ \\
\hline Investigações em Ensino de Ciências & 22 & UFRGS \\
\hline $\begin{array}{l}\text { Revista Ibero-Americana de Estudos em } \\
\text { Educação }\end{array}$ & 21 & UNESP \\
\hline Cadernos de História da Educação & 19 & UFU \\
\hline Revista Educação em Questão & 16 & UFRN \\
\hline $\begin{array}{l}\text { Revista Brasileira de Política e Administração da } \\
\text { Educação }\end{array}$ & 16 & UFRGS \\
\hline Revista Brasileira de Educação Especial & 16 & $\begin{array}{l}\text { ABPEE(Associação } \\
\text { Brasileira de } \\
\text { Pesquisadores em } \\
\text { Educação Especial ) }\end{array}$ \\
\hline Revista Educação & 16 & PUC-RS \\
\hline $\begin{array}{l}\text { Revista Brasileira de Estudos Pedagógicos } \\
\text { RBEP-INEP }\end{array}$ & 15 & INEP \\
\hline Perspectiva & 14 & UFSC \\
\hline Revista de Educação Publica & 12 & UFMT \\
\hline Educação Unisinos & 12 & UNISINOS \\
\hline Acta Scientiarum. Education & 12 & UEM \\
\hline Educação e Filosofia & 11 & UFU \\
\hline Revista Diálogo Educacional & 10 & PUC-PR \\
\hline
\end{tabular}

Fonte: banco de dados SOCED / Plataforma Lattes - CNPq, 2016.

Destaco na tabela 19 a representatividade das instituições de nossa hierarquia institucional como a UFMG, UFRGS e as paulistas UNESP e PUC/SP atuando em áreas temáticas como ciências, políticas públicas e currículo como "nichos temáticos" para suas publicações. De certo, tais revistas com tamanho volume de publicação pelos bolsistas podem indicar um investimento de consagração, um modelo validado de fazer ciência (pelos pares avaliadores das publicações do periódico) da temática dentro da área.

Apesar de serem 380 periódicos A2 há bastante disputa pelo mesmo espaço. Percebermos a grande concentração de publicações em 18 revistas A2. Talvez sejam os periódicos mais consultados da área e, portanto, meio de maior visibilidade e reconhecimento científico.

Sem dúvida, o campo científico é lugar de lutas ideológicas por legitimidade e reconhecimento. As análises desenvolvidas pelos pares podem ser 
compreendidas como resultado de luta simbólica entre os profissionais da área dotados de competências técnicas e sociais desiguais e, portanto, capazes de mobilizar de modo desigual regras disponíveis e armas simbólicas legitimando alguns em detrimento de outros. Diante disto talvez os efeitos da consagração no campo façam a diferença nas possibilidades de publicação, de bolsas e de incentivos.

Observamos também que há poder de revistas de outras instituições como a da UFRN e UFMT que afastadas do centro do poder científico (Sul e Sudeste) também possuem bastante representatividade na divulgação científica no extrato de periódicos A2.

Destacamos novamente a presença forte das associações e entidades, especialmente da publicação Currículo sem fronteiras, que organizada por pesquisadores de várias partes do mundo se propõe a pesquisas integradas e inovadoras que denunciem e proponham inovações na avaliação e política educacional considerando a diversidade ${ }^{49}$. A publicação parece ter força entre os bolsistas de produtividade possuindo 24 publicações dos PQs.

Sobre a presença de periódicos temáticos e de associações e entidades inferimos que se o membro do campo científico não consegue mobilidade no campo de forma individual por não possuir capital social, político e científico suficiente para engendrar mudanças pelos méritos alcançados, há a possibilidade de visibilidade pelo poder das estratégias no jogo (de articulação e de reflexão perante o grupo) por meio das revistas de associações científicas já que nelas há a reunião de membros com relevante capital social, político e científico. Além disso, possibilitam articulação e aproximação com os porta-vozes autorizados do campo, responsáveis pelos mecanismos de regulação e reprodução.

\footnotetext{
49 Ver mais sobre a proposta da revista em: http://www.curriculosemfronteiras.org/manifesto.htm. Acesso em 10/01/2018.
} 
Tabela 20 - Periódicos B1 com maior número de contribuições dos PQs

\begin{tabular}{|l|l|l|}
\hline NOME DO PERIÓDICO B1 & $\begin{array}{l}\text { QUANTIDADE } \\
\text { DE } \\
\text { PUBLICAÇÕES }\end{array}$ & $\begin{array}{l}\text { INSTITUIÇÃO } \\
\text { DO PERIÓDICO }\end{array}$ \\
\hline Revista HISTEDBR On-line & 26 & Unicamp \\
\hline Revista Eletrônica de Educação & 17 & UFSCar \\
\hline Revista Teias & 14 & UERJ \\
\hline Química Nova Na Escola & 14 & $\begin{array}{l}\text { SBQ (Sociedade } \\
\text { Brasileira de } \\
\text { Química }\end{array}$ \\
\hline Inter-Ação & & UFG \\
\hline Em Aberto & 14 & INEP \\
\hline Trabalho \& Educação & 13 & UFMG \\
\hline Linhas Críticas & 10 & UnB \\
\hline Educação Em Foco & 10 & UFJF \\
\hline Cadernos De Educação & 10 & UFPel \\
\hline
\end{tabular}

Fonte: banco de dados SOCED / Plataforma Lattes - CNPq, 2016.

Há maior dispersão nas publicações com menores classificações. Inferimos que tal dispersão deve-se tanto ao grande número de revistas (542) quanto ao baixo valor da revista para avaliação dos programas de pós-graduação e concessão de recursos pelas agências de fomento além da pouca visibilidade do pesquisador.

Entendemos que as disputas no meio acadêmico são também em busca de reconhecimento e, portanto, a competitividade para estarem nas revistas mais bem qualificadas e de maior circulação acaba funcionando como uma competição pela "vitrine" do campo.

O grau de legitimidade, o poder de distinção, acontece mediante as trocas praticadas entre os membros do campo. Estar competindo pelos mesmos espaços em uma revista científica representa a busca por distinguir sua forma de fazer ciência e suas perspectivas teóricas. Representam também mecanismos de alianças com agentes estratégicos entre os pares que podem facilitar a acumulação de capital social e político e o acesso aos financiamentos à pesquisa via visibilidade e afinidade/estratégia científica.

\section{3}

\section{Publicações em periódicos dos PQs por instituições}

Seguiremos tratando das publicações considerando as fronteiras entre os níveis e os elementos institucionais disponíveis para nossa hipótese sobre o poder de algumas instituições no campo que são de certa forma herdadas pelos seus membros, numa relação em que ambos se beneficiam de capitais e distinções no campo tornando-se aquilo que concebemos como a elite do campo. Trabalhar 
sociologicamente com a noção de elite tomando-a como objeto implica admitir que

Toda a sociedade empiricamente observável abrange uma ou várias categorias de pessoas que se consideram, ou que são consideradas, como pertencendo a uma elite, quer seja ao nível da sociedade vista no seu conjunto ou, pelo contrário, num domínio de atividade em particular (COENEN-HUNTHER, 2004 p.10).

Coenen-Hunther (2004, p.14) compreende que falar de elites no plural significa "pensar em elites que competem em torno do mesmo objetivo ou, contrariamente, em diferentes elites especializadas e ativas em diferentes domínios".

A utilização e a caracterização da palavra "elite" pode ser diferente entre as sociedades admitindo-se que algumas pessoas têm mais poder do que outras. Assim, pode designar minoria que possui prestígio e privilégios decorrentes de qualidades naturais/diferenciais tradicionalmente valorizadas socialmente ou qualidades adquiridas por mérito e aptidões. Tratamos em nossa pesquisa das elites especializadas, como é o caso das acadêmicas que são sempre submetidas a julgamentos de agentes de seu próprio campo.

Pensando na distinção analisamos o volume de publicações em periódicos no triênio por instituições para compreender se quem mais publica são aqueles que estão no topo da hierarquia acadêmica da área da Educação. Existe relação entre o volume de publicação e as instituições do topo da hierarquia do campo científico da área da Educação? São elas as que mais produzem?

Atentos as instituições e níveis percebemos que o maior volume de publicação não é, em geral, das instituições mais bem posicionadas na hierarquia que construímos com base em nossos dados, a saber USP, UERJ, UFMG, UNESP e $\mathrm{UFRGS}^{50}$.

Sendo a produção avaliada de acordo com os dados do Currículo Lattes, nos surpreendeu ver que alguns pesquisadores não possuem nenhuma publicação em periódicos no triênio, como um PQ-Sr da PUC-Campinas e um PQ-1B da USP. Talvez sejam esses pesquisadores os avaliados nas exceções do CNPq. Mas se não há o mínimo de 6 publicações no triênio, de acordo com a meta estipuladas para entrar na categoria 1 no nível $\mathrm{D}$, quais seriam as exceções senão os capitais anteriormente acumulados por esses pesquisadores que hoje caracterizam o

\footnotetext{
${ }^{50}$ Devido a extensão da tabela resolvemos incluí-la neste trabalho como apêndice 1.
} 
reconhecimento e acumulação de vantagens perante os demais membros da área? Aliás, considerar a produção dos últimos 10 anos pode ser um fator de preservação dos que estão no nível dos "intocáveis".

As vantagens acumuladas o são porque, em geral, e isso certamente deve variar em função da dinâmica das áreas do conhecimento, a dinâmica do sistema de premiação recai fortemente sobre os indivíduos e suas contribuições passadas mais do que sobre as contribuições presentes. Isso significa que o sistema premia mais os cientistas reconhecidos do que aqueles que ainda não obtiveram esse status.(VICTOR, 2014, p.39). (negritos nossos)

As subjetividades nos remete ao efeito Mateus presente nesse processo. Enquanto alguns pesquisadores adquirem maior destaque e mantêm posições, muitos outros permanecem lutando diante da manutenção da distribuição de reconhecimento e recursos.

O efeito Mateus interfere na dinâmica de produções científicas dos pesquisadores repercutindo na vida acadêmica na medida em que obliteram o processo de aquisição de recursos e financiamentos repercutindo nas avaliações da pós-graduação pela Capes, consequentemente, interferindo no status de suas instituições e o seu de pesquisador (FRANÇA, 2014).

Relembrando o quadro 6 que estipula o volume de publicações exclusivamente em periódicos para a ocupação de cada nível de PQ, sendo o mínimo de 6 publicações exclusivamente em periódicos, resolvemos (desconsiderando a progressão de publicações necessária para cada nível) observar com base no quantitativo mínimo todos os pesquisadores que publicaram menos do que isso ( < 6) durante o triênio (2013-2016), conforme tabela 21. 
Tabela 21 - PQs que publicaram menos do que o mínimo de 6 artigos em periódicos no triênio (2013-2016)

\section{*Legenda:}

$P Q 1 A$

$\mathrm{PQ} \mathrm{Sr}$

$\mathrm{PQ} 1 \mathrm{C}$

$\mathrm{PQ} 1 \mathrm{~B}$

$\mathrm{PQ} 1 \mathrm{D}$

\begin{tabular}{|c|c|}
\hline INSTITUIÇÃO & $\begin{array}{c}\text { NÚMERO DE PUBLICAÇÕES NO } \\
\text { TRIÊNIO (2013-2016) }\end{array}$ \\
\hline UNESP & 5 \\
\hline UNB & 5 \\
\hline UFC & 5 \\
\hline UERJ & 5 \\
\hline UFSC & 4 \\
\hline UFRN & 4 \\
\hline UFRJ & 4 \\
\hline UFMG & 4 \\
\hline UFMG & 4 \\
\hline UERJ & 4 \\
\hline UERJ & 4 \\
\hline USP & 3 \\
\hline USP & 3 \\
\hline UFRJ & 3 \\
\hline UFPR & 3 \\
\hline UFBA & 3 \\
\hline UERJ & 3 \\
\hline PUC-RIO & 3 \\
\hline USP & 2 \\
\hline UNB & 2 \\
\hline PUC-RIO & 2 \\
\hline USP & 1 \\
\hline UFJF & 1 \\
\hline USP & 0 \\
\hline PUC-CAMPINAS & 0 \\
\hline
\end{tabular}

Fonte: banco de dados SOCED / Plataforma Lattes - CNPq, 2016.

Observamos que em todas as categorias há exceções, sendo mais recorrentes entre os pesquisadores do nível 1D com 14 casos. Tal número pode revelar tolerância com relação aos pesquisadores recém chegados na categoria 1 que sendo reconhecidos pelas pesquisas desenvolvidas e pelos capitais acumulados ao 
longo da carreira ${ }^{51}$ estão sendo inseridos na categoria de PQ-1, de distinção acadêmica.

Não podemos desconsiderar também a presença de 4 casos da USP e 4 casos da UERJ. Essas são instituições do topo de nossa hierarquia que possuem programas de pós-graduação consolidados e renomados pesquisadores. Inferimos que estes casos possam ser exceções graças a posição de destaque das instituições desses pesquisadores que, tendo poder no campo científico da área, acabam conseguindo compor a "exceção dos PQs do CNPq" mantendo/conquistando a posição de PQ em relação a outros candidatos à bolsa.

As universidades dos grandes centros urbanos possuem maior visibilidade, pesquisadores mais reconhecidos acumulando maiores possibilidades de conseguir financiamentos. A dinâmica do efeito Mateus expressa nas "exceções" do edital de PQs do CNPq possui implicações nas disparidades de captação de recursos pelas instituições, pois seus parâmetros beneficiam aqueles que mais têm. Há um grande número de cientistas não beneficiados com bolsas de produtividade que têm contribuído para o desenvolvimento da ciência tanto ou mais do que os cientistas que desfrutam de vantagens e recursos, mas que não alcançam o status de bolsistas de produtividade mesmo possuindo os requisitos necessários (BARBOSA, 2016).

As exceções no processo de avaliação e concessão de bolsa nos mostra quem é aquele pesquisador diante da comunidade científica, a força do pertencimento institucional e o papel/atuação/representatividade dos capitais do pesquisador e da instituição no meio acadêmico científico.

Ser bolsista de produtividade gera diferencial para o pesquisador e também para a instituição que acaba atraindo para si mais recursos para pesquisa e desenvolvimento de seus programas de pós-graduação.

Quando olhamos a baixa publicação de alguns pesquisadores na categoria 1 e sua respectivas instituições percebemos o peso das instituições na distribuição de bolsas de produtividade. Embora tenhamos "casos exceções" de pesquisadores de universidades do Nordeste que revelariam uma avaliação diferencial para potencializar a entrada de tais pesquisadores na luta concorrencial de categoria e níveis mais prestigiosos, percebemos que em geral a notoriedade das instituições

\footnotetext{
${ }^{51}$ A idade científica dos pesquisadores $1 \mathrm{D}$ varia de 21 a 38 anos revelando que estão bastante tempo dentro do campo.
} 
(e seus respectivos pesquisadores) das regiões Sul e Sudeste prevalecem. Temos que concordar com a pesquisa de (WAINER e VIEIRA, 2013) sobre as dificuldades de compreensão dos parâmetros avaliativos em função da distribuição das bolsas de produtividade.

Wainer e Vieira (2013) constatam em seu estudo que as decisões do CAs estão altamente correlacionadas com uma métrica histórica (idade) ${ }^{52}$ sendo privilegiados nas avaliações para concessão de bolsas os pesquisadores mais antigos das subáreas ${ }^{53}$. Os autores entendem que há duas vertentes para explicar o objetivo da bolsa de produtividade: premiar cientistas de qualidade ou incentivar a produção de qualidade dos cientistas brasileiros.

Segundo Wainer e Vieira (2013 p.64) a mobilidade dos pesquisadores acaba tornando-se reduzida, pois o números de bolsas para cada categoria é fixo, exceto no nível 2. Há um baixo número de variações nas bolsas $1 \mathrm{~A}$ se comparados ao nível 1D. Os estudiosos inferem que os CAs entendem os pesquisadores participantes do nível 1A como "os intocáveis", indicando que "o componente de prêmio é mais importante para este nível ou que as decisões sobre o nível 1A são mais "políticas" e que, portanto, os CAs se sentem com menos liberdade de tomar decisões que modifiquem o status quo" (WAINER e VIEIRA, 2013 p.76).

De fato, apropriar-se dos capitais institucionais sedimentados para construir sua própria história dentro do campo é saber jogar e reconhecer garantias na elaboração de estratégias no jogo do campo acadêmico acumulando capitais que somados aos capitais/prestígio da instituição de pertença no meio acadêmico geram vantagens consideráveis nas lutas pelo poder e posições de distinção (BOURDIEU, 1998).

\footnotetext{
${ }^{52}$ A métrica histórica que aqui chamamos de idade científica do pesquisador, isto é, ano no qual ele concluiu o doutorado é o nosso apêndice 8.2. Apresentamos a média da idade científica e o intervalo, mas não consideramos que há expressividade em tais dados para uma análise mais minunciosa além da constatação de que a variável de tempo conta para o reconhecimento no campo.

${ }^{53}$ Considerando a métrica histórica como correspondendo a dinâmica de premiação/concessão de bolsas (desempenho ao longo dos anos em virtude de mais serviços e tempo prestado para a comunidade científica, mais alunos formados, etc.), Wainer e Vieira (2013 p.75) ressaltam o impacto negativo dessa dinâmica para os pesquisadores mais jovens visto que, se nenhuma métrica de produção é relevante para receber ou melhorar a bolsa, então, um pesquisador jovem só deve esperar "o tempo passar".
} 
Tabela 22 - Média aproximada do total de publicações em periódicos no triênio (2013-2016) por instituição

\begin{tabular}{|c|c|c|}
\hline $\begin{array}{c}\text { INSTITUIÇÃO }\left(\mathbf{N}^{\circ} \mathrm{DE}\right. \\
\text { PQs) }\end{array}$ & $\begin{array}{c}\text { TOTAL DE PUBLICAÇÕES } \\
\text { DOS PQS DA INSTITUIÇÃO } \\
\text { NO TRIÊNIO (2013-2016) }\end{array}$ & $\begin{array}{c}\text { MÉDIA DE } \\
\text { PUBLICAÇÃO } \\
\text { INSTITUCIONAL POR } \\
\text { TRIÊNIO (2013-2016) }\end{array}$ \\
\hline UEL (2) & 78 & 39 \\
\hline UNEB (1) & 32 & 32 \\
\hline FURG (1) & 28 & 28 \\
\hline UFES (1) & 27 & 27 \\
\hline UEM (2) & 52 & 26 \\
\hline UNIFESP (3) & 76 & 25 \\
\hline $\operatorname{UECE}(1)$ & 22 & 22 \\
\hline UFRGS (13) & 270 & 20 \\
\hline UFBA (3) & 55 & 18 \\
\hline UFPEL (1) & 17 & 17 \\
\hline UNICAMP (8) & 129 & 16 \\
\hline UNESP (14) & 222 & 15 \\
\hline UFU (4) & 62 & 15 \\
\hline UFPR (4) & 60 & 15 \\
\hline UNISINOS (7) & 97 & 14 \\
\hline UFPA (1) & 14 & 14 \\
\hline UEPG (1) & 14 & 14 \\
\hline PUC-Goiás (1) & 14 & 14 \\
\hline UFSCar (12) & 164 & 13 \\
\hline UFRJ (9) & 125 & 13 \\
\hline PUC-RS (6) & 80 & 13 \\
\hline $\mathrm{UFF}(4)$ & 54 & 13 \\
\hline UERJ (14) & 168 & 12 \\
\hline UFMG (14) & 155 & 11 \\
\hline UFRN (3) & 33 & 11 \\
\hline PUC-SP (5) & 51 & 10 \\
\hline UFSM (2) & 20 & 10 \\
\hline UFPB (2) & 21 & 10 \\
\hline UFAL (1) & 10 & 10 \\
\hline UFSC (4) & 38 & 9 \\
\hline UFC (3) & 29 & 9 \\
\hline USP (22) & 177 & 8 \\
\hline UnB (3) & 26 & 8 \\
\hline PUC-Rio (4) & 27 & 7 \\
\hline UFPE (2) & 13 & 6 \\
\hline UTP-PR (1) & 6 & 6 \\
\hline UFJF (1) & 1 & 1 \\
\hline PUC-Campinas (1) & 0 & 0 \\
\hline
\end{tabular}

Fonte: banco de dados SOCED / Plataforma Lattes - CNPq, 2016. 
As instituições menos representativas, isto é, aquelas com menos PQs são as que possuem maior número de publicações. Isto é indicador de um elevado grau de envolvimento dos pesquisadores na luta por produção e representa uma vontade de "existir" no campo científico.

Observamos que a UEL (1C e 1 D), UNEB (1D), FURG (1C), UEM (1C e 1D), UNIFESP (1Sr e 2D), UECE (1B), UFBA (2B e 1D), UFPEL (1D) e UNICAMP (1B, 4C e 3D) possuem um grande volume de publicações, mais de 20 por PQ, corroborando com a hipótese da existência de barreiras subjetivas na mudança de níveis. Há predominância dessas instituições nos níveis 1B, 1C, 1D conforme pode ser visto na tabela 2, com exceção da UNIFESP que possui um PQ-Sr.

A USP que está no topo da hierarquia construída apresenta publicação média de 8 artigos por triênio revelando o poder da legitimidade científica desta instituição diante das políticas avaliativas do CNPq para a concessão de bolsas de produtividade. Tal instituição pode ter mais conforto na dinâmica de sobrevivência, da lógica do publicar ou morrer, em função do prestígio institucional, dos capitais políticos e da qualidade assegurada da produção diante da conjugação da notoriedade institucional ao capital dos pesquisadores.

A posição de destaque da USP na hierarquia institucional ${ }^{54}$ de bolsistas de produtividade compõe uma rede de instituições legítimas que sabem jogar o jogo de forma que são capazes de competir e ao mesmo tempo se autoproteger contra agentes externos que queiram compor/penetrar no campo de legitimidade e de poder.

Se por um lado há o aspecto da tradição a favor da USP sendo uma das pioneiras na criação da Pós-Graduação (SAVIANI, 2000), por outro há o histórico da instituição que diante das barreiras para participação na política científica da área de Ciências Humanas e Sociais (HEY 2008) conquistou seu espaço e hoje luta para manter os "seus pesquisadores representantes" dentre a elite científica de PQs para a manutenção da posição e poder de participação e decisão nas políticas que envolvem as pesquisas da área.

As bolsas de produtividade são sinal de reconhecimento pelos pares. Ser PQ do $\mathrm{CNPq}$ permite a participação em processos importantes para o campo

\footnotetext{
${ }^{54}$ Entendemos que a hierarquia não é única, mas trabalhamos em nossa empiria um olhar para o objeto que nos levaram a tal configuração.
} 
científico da área como definição das regras de avaliação da concessão de bolsas e auxílios à pesquisa, certificação e avaliação de programas de pós-graduação, formulação de políticas públicas em ciência e tecnologia, composição de corpo editorial de periódicos científicos entre uma série de outras atividades que permitem acumulação de capitais na área. Segundo Bourdieu (2014, p.96) as instituições disputam "o monopólio do pensamento e do discurso legítimo sobre o mundo social"'.

As instituições de elite fazem com que os cientistas vinculados a elas ampliem mais precocemente seu potencial de adquirir vantagens diferencialmente cumulativas. As instituições consideradas as hierarquicamente superiores, por possuírem maior número de PQs, apresentam uma publicação média entre 8 e 20 publicações no triênio. É o caso da USP que ao apresentar 8 publicações por triênio representa a força da consagração institucional visto as demais instituições apresentarem números superiores de publicações: 11 (UFMG), 12 (UERJ), 15 (UNESP) e 20 (UFRGS) publicações no triênio.

Tais números podem indicar uma competição entre essas instituições por espaço no campo científico buscando níveis mais elevados no qual seus agentes seriam capazes de exercer seu poder/força nas relações políticas e entre as posições sociais "regulando" de alguma forma as regras do jogo no campo. Aliás, se retornarmos as tabelas 18,19 e 20 veremos que o poder dessas instituições está materializado na posse de periódicos e no reconhecimento dos mesmos expresso tanto pela avaliação no Web Qualis quanto no volume de publicações recebidas pelos PQs 1 da área.

O sistema de recompensas, a alocação de recursos e outros sistemas de seleção social criam e mantêm uma estrutura de classes na ciência ao proporcionar uma distribuição estratificada de trabalho científico significativo entre os cientistas, já que as instituições mais financiadas e prestigiosas atraem os estudantes mais promissores, concentram e mantêm os cientistas mais premiados e considerados excelentes (MERTON, 1988 apud BARBOSA, 2016 p.301)

Os pesquisadores renomados e as instituições de prestígio acabam sendo quase uma unidade diante da reciprocidade e parceria na atuação. Se a instituição empresta o seu nome e destaque nacional (em alguns casos até internacional), credibilidade e visibilidade aos seus pesquisadores elas recebem, em contrapartida, mais financiamento e atraem os cientistas mais consagrados e 
reconhecidos do campo. Mais uma vez constata-se a presença do efeito Mateus agregado ao valor institucional e não apenas do agente.

Para Bourdieu o poder/legitimidade da academia por meio das instituições para conceder distinções é parte de uma economia dos bens simbólicos que alimenta o autoengano coletivo por meio do qual as instituições mistificam os agentes e se perpetuam. Para o autor, o nexo estreito entre ciência, autoridade e poder está imbricado nas honras do meio acadêmico. (BOURDIEU apud WACQUANT, 2013).

A consagração que as instituições concedem a pessoas, objetos ou atos apresentam um perigo, pois envolvem os "elevados" por elas em uma teia de expectativas coletivas, obrigações estatutárias e vínculos organizacionais que podem paralisar, ou mesmo, neutralizar suas ações em uma díade entre o poder científico e o poder político (WACQUANT, 2013; HEY, 2008).

O que vemos nas tabelas de 18 a 22 é a existência do poder simbólico de algumas instituições no campo para a manutenção de um status elevado de prestígio e poder dentro da área da Educação. Destacamos o caso das instituições paulistas que conseguem manter o prestígio de seus periódicos e de seus pesquisadores e, em especial da USP, que consegue manter sua posição com um volume de publicações de 0 a 24 publicações no triênio. 
Tabela 23 - Média do total de publicações em periódicos por pesquisador durante toda a carreira por instituição

*Trata-se de uma estimativa

\begin{tabular}{|c|c|c|}
\hline $\begin{array}{c}\text { INSTITUIÇÃO }\left(\mathbf{N}^{\circ} \mathrm{DE}\right. \\
\text { PQs) }\end{array}$ & $\begin{array}{c}\text { TOTAL DE } \\
\text { PUBLICAÇÕES }\end{array}$ & $\begin{array}{c}\text { MÉDIA DE } \\
\text { PUBLICAÇÃO } \\
\text { POR } \\
\text { PESQUISADOR* }\end{array}$ \\
\hline UEL (2) & 218 & 109 \\
\hline UFRGS (13) & 1262 & 97 \\
\hline PUC-Goiás & 85 & 85 \\
\hline UEM (2) & 167 & 83 \\
\hline UFU (4) & 325 & 81 \\
\hline UNEB & 75 & 75 \\
\hline UFBA (3) & 222 & 74 \\
\hline UFES & 72 & 72 \\
\hline UNISINOS (7) & 481 & 68 \\
\hline UNESP (14) & 938 & 67 \\
\hline UECE & 65 & 65 \\
\hline UNICAMP (8) & 505 & 63 \\
\hline FURG & 63 & 63 \\
\hline UNIFESP (3) & 187 & 62 \\
\hline UFSM (2) & 125 & 62 \\
\hline PUC-Campinas & 61 & 61 \\
\hline UFAL & 61 & 61 \\
\hline PUCRS (6) & 360 & 60 \\
\hline USP (22) & 1307 & 59 \\
\hline UERJ (14) & 825 & 58 \\
\hline UFRJ (9) & 519 & 57 \\
\hline UFPEL & 57 & 57 \\
\hline UFSCar (12) & 680 & 56 \\
\hline UFMG (14) & 777 & 55 \\
\hline UFF (4) & 213 & 53 \\
\hline UFSC (4) & 207 & 51 \\
\hline PUC-Rio (4) & 193 & 48 \\
\hline UFC (3) & 140 & 46 \\
\hline PUC-SP (5) & 225 & 45 \\
\hline UFPR (4) & 176 & 44 \\
\hline UEPG & 44 & 44 \\
\hline UTP-PR & 39 & 39 \\
\hline UFPA & 37 & 37 \\
\hline UFRN (3) & 105 & 35 \\
\hline UnB (3) & 102 & 34 \\
\hline UFJF & 28 & 28 \\
\hline UFPE (2) & 49 & 24 \\
\hline UFPB (2) & 40 & 20 \\
\hline
\end{tabular}

Fonte: banco de dados SOCED / Plataforma Lattes - CNPq, 2016. 
Ao hierarquizarmos o volume de produção média de publicações em periódicos, o maior número de publicações é da instituição UEL que possui apenas dois bolsistas PQ 1, nos níveis 1C e 1D, respectivamente. Talvez esse dado seja um indicativo da força que PQs dessa instituição fazem para manter a posição no campo, conforme já mencionado anteriormente.

Quando relacionamos essa tabela sobre a produção média em periódicos dos PQs 1 com a tabela 2 que indica o nível de cada bolsista, observamos que as instituições mais representativas dentro da hierarquia institucional que construímos (são elas USP, UERJ, UFMG, UNESP e UFRGS), não são as que possuem a maior média de publicações em periódicos, exceto a UFRGS.

Em nossa pesquisa consideramos o poder da consagração como elemento de distinção e manutenção da posição em função do modelo de políticas avaliativas vigentes que consideram além do volume, aspectos subjetivos quando tratam da inserção, engajamento e produção científica do pesquisador. Mas outra possibilidade explicativa para o menor volume de publicações, quando olhamos para a média da totalidade de publicações das instituições mais consagradas, pode ser o fato de tais instituições - que estão no topo da hierarquia - estarem a mais tempo no campo, antes mesmo da instauração da lógica do publicar ou morrer.

Ao longo de toda a carreira os capitais acumulados se deram em torno de sua qualidade de pesquisador avaliada de diversas formas, não só por meio de publicações, demonstrando o potencial de tais pesquisadores no poder de definir as regras do jogo.

Para Bourdieu a autoridade científica é um misto de competência técnica e reconhecimento dos pares, mediado pelas instâncias oficiais, no caso o CNPq. As instituições hierarquicamente mais bem representadas entre os PQs não são as que mais produzem. A tomada de posições, apesar de parecer simples contribuições ao progresso da ciência, devem ser tratadas como “"“estratégias políticas” que visam (através de teorias, métodos e conceitos) instaurar, restaurar, reforçar, salvaguardar ou derrubar uma determinada estrutura de relações de dominação simbólica"55 (BOURDIEU, 2007 p.171).

As instituições acumulam capital simbólico, assim como o político, e tentam manter e controlar a posição conquistada no decurso da história pelo

${ }^{55}$ É valido ressaltar que apesar do "peso" dos termos utilizados por Bourdieu (2007 p.171), para ele "as estratégias podem permanecer perfeitamente inconsciente". (grifos meus) 
reconhecimento e fidelidade de uma rede de agentes e instituições parceiras capazes de gerar ainda mais vantagens através de capitais políticos e sociais.

França (2014) em sua pesquisa sobre a gestão dos programas de pósgraduação alerta sobre a injusta associação entre mérito e fomento que tende a favorecer os programas e instituições mais bem estruturados que conseguem atingir os critérios de qualidade com mais facilidade obedecendo a lógica das avaliações vigentes.

Tabela 24 - Total de publicações em periódicos por Região do país com número médio (aproximado) de publicações e idade científica

\begin{tabular}{|c|c|c|c|c|}
\hline $\begin{array}{c}\text { REGIÃO DO } \\
\text { PAÍ́S }\end{array}$ & $\begin{array}{c}\text { NÚMERO } \\
\text { TOTAL DE } \\
\text { PQS POR } \\
\text { REGIÃO }\end{array}$ & $\begin{array}{c}\text { NÚMERO } \\
\text { TOTAL DE } \\
\text { PUBLICAÇÕ } \\
\text { ES }\end{array}$ & $\begin{array}{c}\text { MÉDIA DE } \\
\text { PUBLICAÇÕES } \\
\text { DOS PQS POR } \\
\text { REGIÃO }\end{array}$ & $\begin{array}{c}\text { MÉDIA DA } \\
\text { IDADE } \\
\text { CIENTÍFICA }\end{array}$ \\
\hline SUDESTE & 116 & 6855 & 59 & 24 anos \\
\hline SUL & 44 & 3199 & 72 & 22 anos \\
\hline CENTRO-OESTE & 4 & 187 & 47 & 20 anos \\
\hline NORTE & 1 & 37 & 37 & 22 anos \\
\hline NORDESTE & 16 & 757 & 47 & 18 anos \\
\hline
\end{tabular}

Fonte: banco de dados SOCED / Plataforma Lattes - CNPq, 2016.

A tabela 24 mostra que a região Sul apresenta o maior volume médio de publicação seguida pela região Sudeste. Embora já tenhamos elucidado as questões referentes a publicação, nesta tabela temos também a idade científica média revelando que estarem mais ou menos tempo no meio científico não seria o suficiente para justificar a grande diferença no quantitativo de bolsistas e na produção.

Apesar de serem feitas considerações a respeito do necessário incentivo/ financiamento para pesquisas das regiões Norte e Nordeste concedendo também distinções, as assimetrias regionais permanecem. A cooperação científica se autoreforça em torno dos mesmos porque (consagrados) acabam tendo mais condições materiais e simbólicas de fazer algo pelo progresso da ciência. Os beneficiários tanto no sistema de publicações quanto no acesso aos meios de financiamento/produção científica (material e simbólica) são sempre os mesmos. 


\section{5 \\ O WebQualis e a hierarquia de instituições: quais as relações possíveis?}

Está claro que todas as estratégias de dominação não seriam nada sem as estruturas que as fazem possiveis e eficazes.

(BOURDIEU, 2014 p.119)

Para Bourdieu (1989) a produção das ideias acerca do mundo social acha-se sempre subordinada à lógica de lutas concorrências e da conquista do poder. Nesse jogo de lutas simbólicas, por poder e posição "vantajosa" no campo, resolvemos analisar o Qualis. Sistema de avaliação que em nosso desenho de pesquisa inferimos refletir também o poder de algumas instituições.

O Qualis é o conjunto de procedimentos utilizados pela Capes para avaliar a produção científica dos programas de pós-graduação. Ele foi concebido para atender as necessidades específicas do sistema de avaliação e é baseado nas informações fornecidas por meio do aplicativo Coleta de Dados.

O Qualis afere a qualidade dos artigos e de outros tipos de produção a partir da análise da qualidade dos veículos de divulgação, ou seja, periódicos científicos que tenham recebido produção no ano ou no período de classificação ${ }^{56}$.

No Web Qualis podemos consultar a classificação do periódico nas diferentes áreas. A classificação dos periódicos é realizada pelos comitês consultores de cada área de avaliação e passa por processo anual de atualização. Esses veículos são enquadrados em extratos indicativos da qualidade - A1, o mais elevado; A2; B1; B2; B3; B4; B5; C - com peso zero. O mesmo periódico, ao ser classificado em duas ou mais áreas distintas, pode receber diferentes avaliações. A classificação é realizada pelos comitês de consultores de cada área de avaliação seguindo critérios previamente definidos pela área ${ }^{57}$.

Apenas os periódicos que tenham recebido produção no período de classificação (quadrienal) serão listados e classificados pelo Web Qualis.

\footnotetext{
${ }^{56}$ No que se refere aos artigos publicados em periódicos científicos, essa avaliação poderá ser consultada através do aplicativo Web Qualis disponível em: https://sucupira.capes.gov.br/sucupira/public/consultas/coleta/veiculoPublicacaoQualis/listaConsul taGeralPeriodicos.jsf. Acesso em: 24/12/2018..

${ }^{57}$ Os critérios gerais e os específicos utilizados em cada área de avaliação da CAPES estão disponibilizados nos respectivos Documentos de Área.
} 
Portanto, não se trata de uma lista exaustiva de periódicos, mas sim uma lista dos periódicos efetivamente utilizadas pelos pesquisadores no quadriênio analisado.

A Capes e CNPq lançam mão do sistema Qualis como uma estratégia avaliativa que, por sua vez, podem refletir hierarquias institucionais presentes no campo científico. O sistema Qualis representa uma posição desencadeadora de estratégias para os PQs que jogam o jogo do campo científico. As estratégias classificatórias que definem o Qualis dos periódicos são também mobilizadas por agentes do campo que visam a legitimação de suas convicções sobre o que é fazer ciência e de como ela deve ser comunicada. De fato, a Qualis tem efeitos significativos nas classificações na comunidade científica.

Diante da relevância do Web Qualis para a avaliação dos programas de pósgraduação e das bolsas de produtividade buscamos conhecer quem são as instituições responsáveis pelas revistas mais bem qualificadas da área, a saber as revistas com Qualis 1A e 2A ${ }^{58}$ da área da Educação. Entendemos que o Qualis nas avaliações tem função de seriação selecionando os mais aptos para receber incentivos para a pesquisa, mas também fazem parte de um jogo político que legitima capitais e instituições.

As participações em comissões ${ }^{59}$ e entidades com poder de decisão como, também, criação de periódicos científicos são formas de poder legitimada pelas avaliações do Qualis. Alguns periódicos conseguem conquistar uma boa qualificação na área em virtude dos agentes e/ou instituições aos quais pertencem. O contato da rede que se estabelece em torno da elite científica da área, capitaliza em forma de publicações em suas revistas bem qualificadas no Web Qualis, adquirindo vantagens no campo diante não só do $\mathrm{CNPq}$, mas também da Capes e demais agências de fomento que utilizam tal base como parâmetro avaliativo da qualidade da produção de um pesquisador.

Nada há que seja exigido de modo mais absoluto pelo jogo político do que esta adesão fundamental ao próprio jogo, illusio, involvement, commitment, investimento no jogo que é produto do jogo ao mesmo tempo que é a condição do funcionamento do jogo: todos os que têm o privilégio de investir no jogo (...), pelo mesmo investimento fundamental no jogo de que eles têm o monopólio e que precisam de perpetuar para assegurarem a rentabilidade dos seus investimentos,

\footnotetext{
${ }^{58}$ Não inserimos nesta etapa da tese as revistas Qualis B1 em função da grande quantidade de revistas (542) e a baixa concentração das publicações em determinadas revistas conforme visto na tabela 20.

${ }^{59}$ Devido ao grande número de dados ausentes sobre a participação em comissões e entidades registradas no Currículo Lattes optamos por agregar as nossas análises apenas dados das publicações para a construção de nossa pesquisa.
} 
não se manifesta nunca de modo tão claro como quando o jogo chega a ser ameaçado enquanto tal. (BOURDIEU, 1998 p.172)

O Qualis representa a relação de forças, lutas concorrenciais e estratégias no campo através da manutenção e controle dos meios legitimados para a divulgação científica. Com dossiês temáticos que privilegiam as agendas da instituição detentora da revista e pesquisadores convidados para a manutenção da "excelência" do periódico, resta pouco espaço para pesquisadores externos à instituição que, geralmente são submetidos a longos períodos de avaliação de seus artigos para publicação (demorando de 3 meses a 1 ano).

Podemos considerar que embora não generalizável esse padrão bastante conhecido das revistas científicas (FRANÇA, 2014; NASCIMENTO, 2016; BARBOSA, 2016; LEITE e NETO, 2017 entre outros) é uma forma de monopolizar a legitimidade científica como também de manter posições e ascender na medida em que cria-se uma rede do cientificamente validado por tais pesquisadores/instituições. Nas palavras de Bourdieu (1998, p.150) classificar significa

ter a possibilidade de objectivar todas as formas de objectivação, do insulto singular à nomeação oficial, sem esquecer a pretensão, característica da ciência na sua definição positivista e burocrática, de arbitrar essas lutas em nome da "neutralidade axiológica".

Nascimento e Bufrem (2016 p.16) questionando a crença dos avaliadores sobre possuírem o ponto de vista científico ideal e os critérios mais isentos de avaliação afirma que "ninguém é bom juiz quando além dessa função desempenha outra: a de réu".

Resolvemos, então, investir em conhecer esses veículos bem classificados de divulgação científica para ver se há relação entre o poder institucional e o poder dos meios de divulgação científica já que a possibilidade de publicação nessas revistas mais bem qualificadas constituem pré-requisito para o alcance de financiamento e das bolsas de produtividade, conforme já mencionado anteriormente.

Para apresentarmos a qualificação dos periódicos A1(121 revistas) e A2 (380 revistas) na área da Educação, consultamos as avaliações do quadriênio 
2013-2016 através do Web Qualis ${ }^{60}$ selecionando as revistas e, posteriormente, consultando as instituições responsáveis pelas mesmas.

\section{Tabela 25 - Número de revistas nacionais e internacionais Web Qualis A1 e} A2*

*Percentual calculado aproximado.

\begin{tabular}{|c|c|c|}
\hline Web Qualis & A1 & A2 \\
\hline Nacional & $82(68 \%)$ & $181(48 \%)$ \\
\hline Internacional & $39(32 \%)$ & $199(52 \%)$ \\
\hline Total & $121(100 \%)$ & $380(100 \%)$ \\
\hline
\end{tabular}

Fonte: banco de dados SOCED / Plataforma Lattes - CNPq, 2016.

A seleção dos periódicos avaliados no sistema Qualis é feita em função da publicação dos pesquisadores. Observando a tabela 25 percebemos que existe uma grande preocupação dos pesquisadores em publicar em periódicos internacionais chegando a $52 \%$ o percentual de pesquisadores que publicam em revistas A2.

Barbosa (2016, p.305) em seu artigo que trata sobre as implicações éticas do efeito Mateus na ciência revela que "atribui-se menor pontuação aos artigos publicados em periódicos brasileiros do que aos periódicos estrangeiros, cujo fator de impacto científico geralmente é maior do que o dos periódicos brasileiros.

Corroborando com essa afirmação Rodrigues (2011) em seu artigo Publicar mais ou publicar melhor? diz que os artigos completos em periódicos indexados internacionais possuem grande impacto na comunidade científica (em função do número de consultas e citações) e possuem maior pontuação em concursos e progressão de carreira, além de maior impacto nos índices de pontuação/avaliação de publicações científicas.

Aqui é que o tamanduá torce o rabo: para vencer a corrida ele deve falar inglês, ou seja, no sistema de classificação utilizado, a principal qualidade de um pesquisador brasileiro é sua capacidade de publicar artigos em inglês. O sistema de pontuação está de acordo com a concepção de que um artigo publicado em inglês é melhor do que qualquer outro publicado em português ou em qualquer outra língua. (RODRIGUES, 2011 p.459)

Sendo importante ser lido e citado para a conquista de notoriedade e capital científico puro na área, cada vez mais há demanda por publicações em periódicos bem qualificados e internacionais.

\footnotetext{
${ }^{60}$ Para esse levantamento utilizamos a avaliação do Web Qualis referente ao quadriênio 20132016, considerando o recorte temporal de nossa pesquisa. Disponível em: https://sucupira.capes.gov.br/sucupira/public/consultas/coleta/veiculoPublicacaoQualis/listaConsul taGeralPeriodicos.jsf. Acesso em: 29/09/2018.
} 
Nacionais ou internacionais, a tabela 25 nos mostra que existe uma grande peneira na mudança de categoria entre os periódicos. Há apenas 121 periódicos A1 enquanto há 380 periódicos A2. Infiro que a quase equivalência entre periódicos nacionais (181) e internacionais (199) na categoria A2 não é algo ao acaso. Pode ser representativo da força de investimentos (para além dos intelectuais) para conquistar publicações bem qualificadas e que respeitem a máxima da internacionalização. Sobre isso, vale consultar o artigo de Barbosa (2014) que denuncia o alto custo de publicar em periódicos estrangeiros que exigem a assinatura de seus colaboradores, como a Elsevier.

A ciência tem se tornado bastante competitiva em nosso país tanto na busca de financiamento quanto na luta por mercado e desenvolvimento. As ações e intencionalidades institucionais têm prevalecido diante da crescente importância dos interesses de diferentes naturezas sobre a Educação. Algumas pautas de pesquisa parecem não compor uma agenda que busca investigar processos do fenômeno humano e temos que lidar com pesquisas cada vez mais aligeiradas e fragmentadas ${ }^{61}$. Para suprir a necessidade de sobressair no campo, os pesquisadores buscam temas e pesquisas "inéditos" ou mesmo migram para linhas de pesquisa que supunham ser menos concorridas no intuito de conseguirem reconhecimento científico e alcançarem mais chances de publicar e serem lidos e citados.

Diante da classificação oficial do Qualis publicar em periódicos avaliados tornou-se importante para divulgação científica e também para participar dos rankings de prestígio como o das principais revistas A1 e A2, apresentadas nas tabelas 18 e 19.

As políticas de Estado estão mais preocupadas com os resultados de que com os processos (FRANÇA, 2014). Num ambiente de intensa concorrência os pesquisadores parecem planar na tríade produtividade, performatividade e accountability que nos leva a questionar a corrida por publicar, ser "reconhecido" no campo e contabilizar pontos para conquistar uma boa posição na luta por financiamento de suas pesquisas.

\footnotetext{
${ }^{61}$ É valido ressaltar que tais problemas já eram apontados por Bernadette Gatti em artigo escrito em 1983, onde ela ressalta a tendência dos pesquisadores a privilegiar temas definidos pelas instâncias de financiamento seguidos por uma sucessão descontinua de trabalhos pelos grupos de pesquisa além de grande dispersão de temas.
} 
A "selva da divulgação científica" e a lógica de corrida por garantir a produtividade têm divulgado mais processos de pesquisa do que resultados. $\mathrm{Na}$ luta por garantir a autoria de pesquisa em determinados temas, os pesquisadores acabam publicando bons trabalhos que muitas vezes não revelam resultados, apenas processos e hipóteses. As agendas de pesquisa e a parceria de laboratórios nem sempre são possíveis. Se por um lado, a existência do "nome próprio" pode ser motivo de resistência a parcerias, por outro na luta concorrencial tais sujeitos escolhem com quem e se pretendem colaborar com pesquisadores que ainda buscam o reconhecimento (HEY, 2008).

A competitividade acadêmica e a presença da avaliação da Capes e do CNPq via Qualis geram modificações no sistema de produção científica e também podem gerar mudanças na lógica de funcionamento do campo da pesquisa em Educação como elucidado.

O sistema Qualis hoje reflete as hierarquias presentes no campo científico da Educação. Considerando o seu poder de classificação e hierarquização optamos por trabalhar com o Qualis dos periódicos nacionais das categorias A1 e A2 para conhecer quais instituições podem estar, via a posse de periódicos, definindo o padrão científico de qualidade da área. Entendemos a posse de periódicos como trunfos estratégicos, para seus membros PQs, enquanto domínio prático da lógica do campo para publicar nos melhores periódicos da área e acumular vantagens.

Se a estrutura do campo social é definida em cada momento pela estrutura da distribuição do capital e dos ganhos característicos dos diferentes campos particulares, é certo em todo o caso que em cada um desses espaços de jogo, a própria definição daquilo que está em jogo e dos vários trunfos pode ser posta em jogo. Todo campo é lugar de uma luta mais ou menos declarada pela definição dos princípios legítimos de divisão do campo. (BOURDIEU, 1998, p.150) 
Tabela 26 - Instituições nacionais responsáveis pelas revistas Qualis A1

\begin{tabular}{|l|c|}
\hline INSTITUIÇÃO & QUANTIDADE ${ }^{62}$ DE REVISTAS A1 \\
\hline USP & 13 \\
\hline UNICAMP & 13 \\
\hline UFRGS & 8 \\
\hline UNESP & 7 \\
\hline UFMG & 5 \\
\hline UEM & 4 \\
\hline $\begin{array}{l}\text { ANPEd- Associação Nacional de Pós- } \\
\text { Graduação em Educação }\end{array}$ & 4 \\
\hline UFSM & 3 \\
\hline UFPR & 3 \\
\hline Fundação CESGRANRIO & 3 \\
\hline UNIFESP & 2 \\
\hline Fundação Carlos Chagas & 2 \\
\hline UFSC & 2 \\
\hline FIOCRUZ & 2 \\
\hline UFPEL & 2 \\
\hline UnB & 2 \\
\hline Associação Nacional de Pós-Graduação \\
em Ciências & 2 \\
\hline UFF & 2 \\
\hline UNISO E UNICAMP & 1 \\
\hline PUC/SP & 1 \\
\hline UERJ & 1 \\
\hline Total & 82 \\
\hline
\end{tabular}

Fonte: banco de dados SOCED / Plataforma Lattes - CNPq, 2016.

Observando a tabela 26 podemos constatar que, com exceção do periódico da UnB, todas as demais instituições responsáveis pelas publicações Qualis A1 são das regiões Sul e Sudeste contribuindo para a retórica das instituições responsáveis pela boa ciência. Será que fatores referentes ao impacto não consideram as diferenças regionais? Será que existe alguma barreira - para além das geográficas - que desconsideram a relevância da produção e inibem a consulta de periódicos de outras regiões do país que não as regiões marcadas pelo incentivo e representatividade diante de ações? Estas são indagações que considero extrapolar o escopo dessa pesquisa, mas que seriam bastante relevantes para a ampliação da participação da comunidade científica das regiões Norte, Nordeste e Centro-Oeste.

Inferimos que os pesquisadores das regiões Sul e Sudeste possuem legitimidade e credibilidade em seu fazer científico pelos mesmos motivos que

62 É importante ressaltar que o Web Qualis registra e qualifica as publicações também considerando seu veículo de divulgação (impresso, digital, etc.). Portanto, algumas publicações, de uma mesma instituição, aparecem mais de uma vez no Web Qualis devido aos diferentes meio de divulgação. Optamos por não trabalhar com a exclusão das repetições considerando-as como um fator importante no que diz respeito as notoriedade dessas revistas, visto que só são cadastradas e avaliadas pelo Qualis as revistas nas quais os pesquisadores publicam. 
geram a tendência de buscar formação nessas regiões, como já assinalamos anteriormente. Tal fato torna os periódicos das instituições dessas duas regiões mais procurados para publicar, consultar e, portanto, possuem maior circulação no meio acadêmico sendo legitimados pela Qualis em sua avaliação sobre circulação, qualidade e periodicidade na composição do extrato mais distinto, Qualis A1.

A Qualis é capaz de distinguir instituições por meio dessa seleta avaliação. Na tabela 26 há apenas 21 instituições que comandam os principais periódicos nacionais da área, tendo apenas duas associações científicas. Se considerarmos os 178 programas de pós-graduação ${ }^{63}$ em funcionamento na área da Educação percebemos que é bastante restrito o comando das revistas científicas da área.

Embora seja notório que há disparidades em termos de desenvolvimento educacional entre as regiões, é evidente que existe uma concentração de incentivos e uma tendência das políticas avaliativas privilegiarem os que mais possuem condições de alcançar as metas propostas.

São Paulo é responsável por 39 periódicos qualificadas pelo Web Qualis A1, cerca de $47 \%$ do total dos 82 periódicos nacionais. São seis instituições paulistas com destaque para USP e Unicamp com 13 periódicos cada.

A USP criou seu primeiro periódico científico em 1955. A Revista de Pedagogia da Universidade de São Paulo acabou por não ter sequência depois de alguns anos, mas indica que, desde antes da criação e expansão da pós-graduação, a universidade paulista já estava engajada em fazer ciência e a respectiva divulgação científica na área da Educação. (GATTI, 1983).

A elite conhece as regras do jogo para publicar nas melhores revistas e suas instituições possuem os periódicos mais bem qualificados do país. Apontando para o crescente números de publicações em periódicos Nascimento e Bufrem (2016, p.14) ressaltam o "sistema retroalimentativo das publicações periódicas", pois enquanto principal canal de comunicação científica são também as mais citadas “reforçando o efeito Mateus não só para o agente (autor), mas também para o veículo (revistas científicas)".

Tal fato é percebido nos gráficos 1 e 2 que apresentam o volume de publicação dos PQs Sêniors e PQs-1A distribuídos por extratos (A1,A2,

\footnotetext{
${ }^{63}$ Dados consultados em: https://sucupira.capes.gov.br/sucupira/public/consultas/coleta/programa/listaPrograma.jsf. Acesso em: 05/11/2018.
} 
B1,B2,B3,B4.B5,C) da Qualis. ${ }^{64}$ A posição de elite científica é representada pela alta proporção de artigos A1 e A2 dos PQs 1A e Sênior.

Gráfico 1 - Volume da produção distribuído nas respectivas Qualis - PQs-Sr

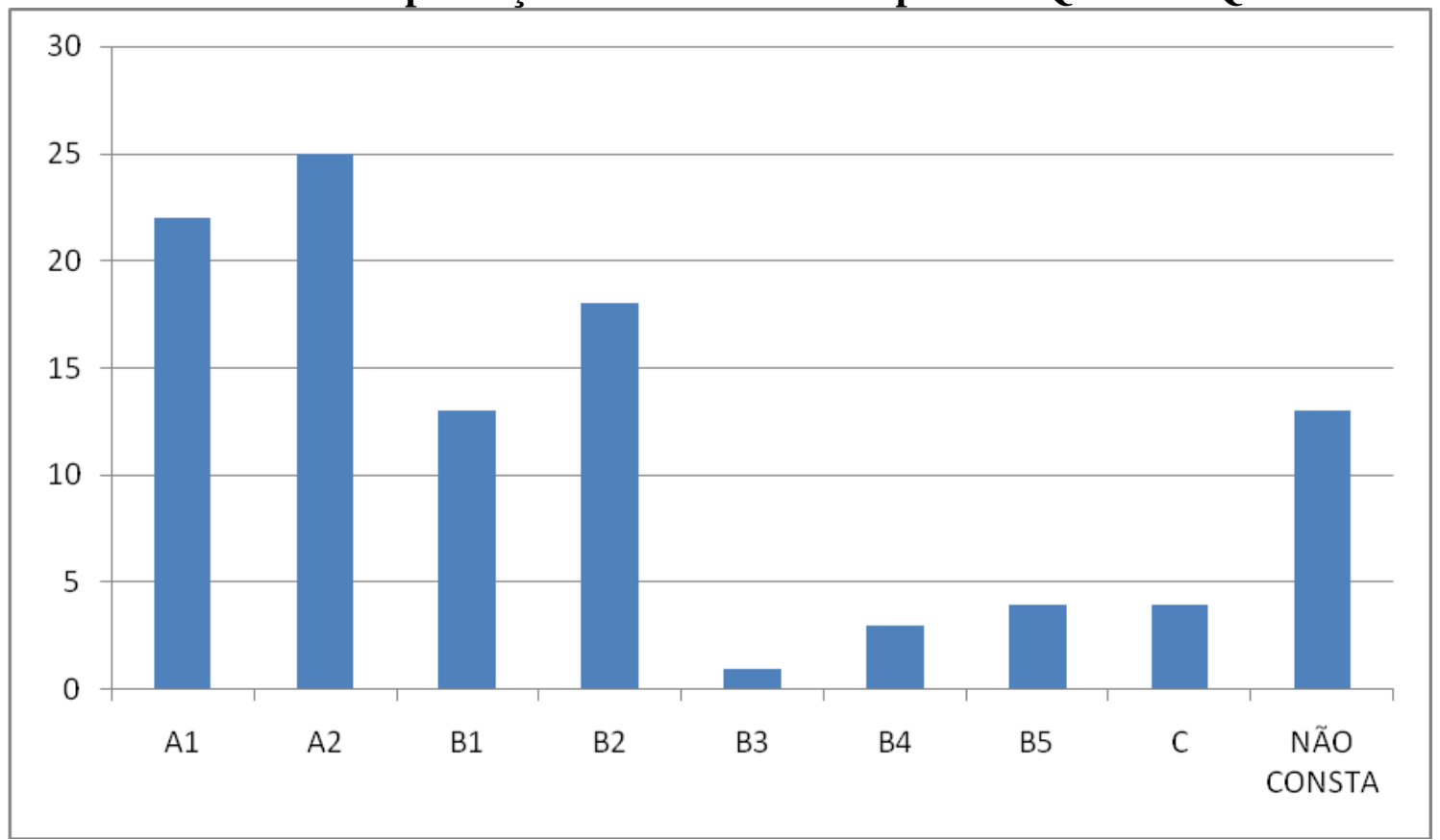

Fonte: banco de dados SOCED / Plataforma Lattes - CNPq, 2016.

Os dados demonstram que os PQs-Sr tendem a publicar nos periódicos mais bem qualificados da área, predominantemente A1 e A2.

Percebemos que não há muito investimento para publicar em revistas B1, mas há bastante publicações em B2 talvez decorrente do empréstimo do prestígio científico para elevação do periódico diante da avaliação do Web Qualis.

Não observamos concentração de publicações em extratos inferiores a B2.

A elite consagrada (PQs) publicou mais nas melhores revistas científicas porque é elite, ou é elite porque publicou, prioritariamente, nos estratos mais elevados? A resposta tangencia a questão do rito da investidura (BOURDIEU, 2015), pois o acesso da elite empossada é mais facilitado. (NASCIMENTO e BUFREM, 2016, p.15)

O rito de investidura é aqui entendido como ritos e processos simbólicos pelos quais o indivíduo adquire seu status social implicando em reconhecimento e crença neste status com performance da produtividade condizente com as regras do campo (NASCIMENTO, 2016).

\footnotetext{
64 Nos gráficos o "NÃO CONSTA" é representado pelos periódicos para os quais não conseguimos encontrar a Qualis (quadriênio 2013-2016) correspondente. Em geral são publicações estrangeiras e/ou bastante diversificadas.
} 
Gráfico 2 - Volume da produção distribuído nas respectivas Qualis - PQs-1 ${ }^{\text {a }}$

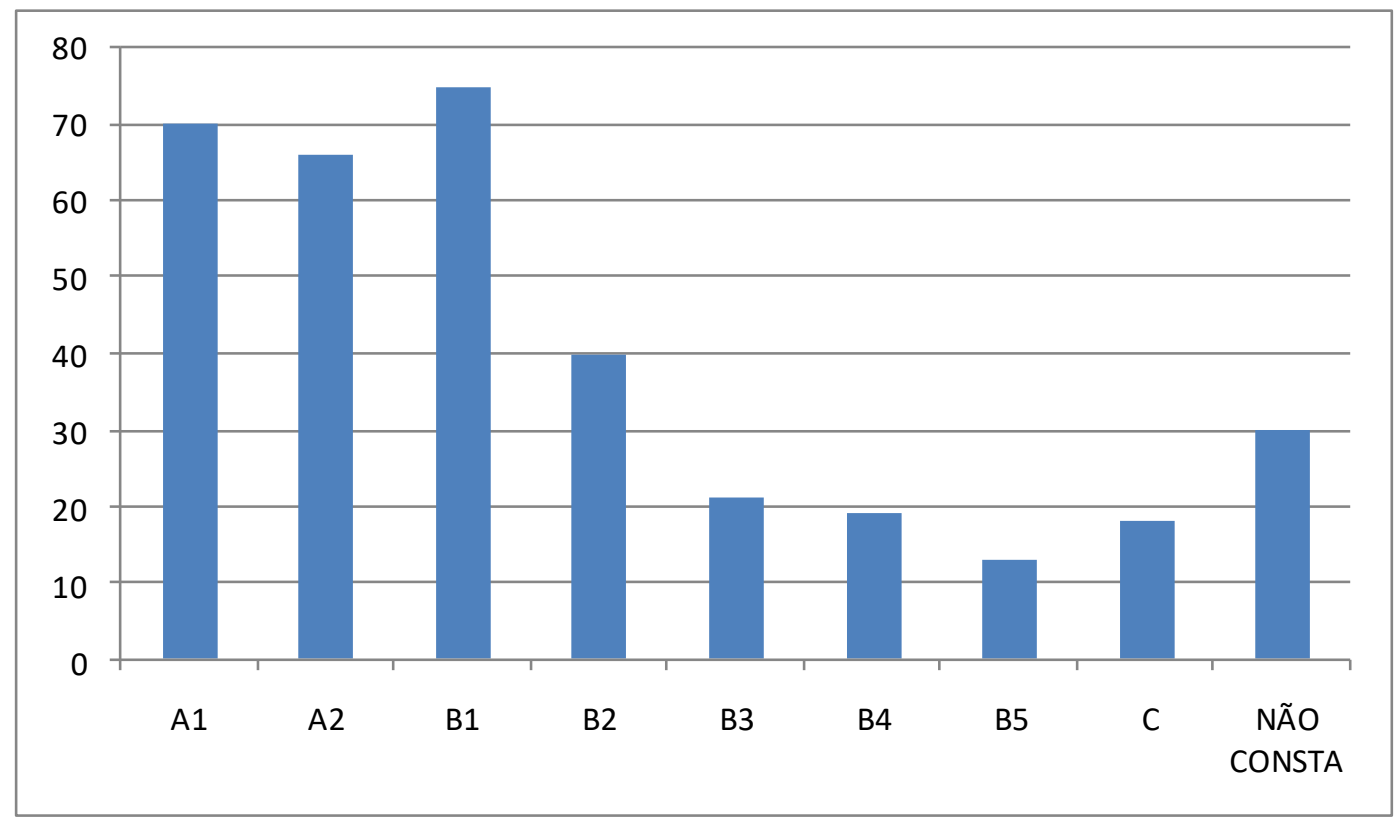

Fonte: banco de dados SOCED / Plataforma Lattes - CNPq, 2016

A maioria dos artigos que consultamos e não encontramos a classificação no Web Qualis são oriundos de publicações estrangeiras, presentes em “não consta".

Dentre os pesquisadores há um pequeno grupo de pesquisadores que publicam em todos os extratos. Dentre estes nota-se publicações em algumas revistas repetidas vezes, talvez com a intenção de melhorar a avaliação do periódico.

Apesar de publicarem mais nos extratos mais bem qualificados mostra-se que esses pesquisadores também impulsionam revistas com Qualis inferiores ao publicar em diversos extratos. Dentre essas revistas com baixa qualificação que recebem mais publicações dos PQs-1A, destaco: Trabalho Necessário (B3) e Nueva América (B4).

A elite parece numa troca de favores citar e ser citada criando a necessidade do periódico no meio acadêmico da área. Alguns PQs-1A demonstram esforço em publicar repetidas vezes em algumas revistas abaixo do extrato B2 para alavancar melhores qualificações.

Diante da necessidade da produtividade dos pesquisadores percebemos o esforço das instituições em possuir os meios de produção /publicação para entrar na corrida de um sistema de avaliação de artigos considerado por muitos como "fechado e tendencioso devido à possibilidade de desvios em favor de cientistas reconhecidos de universidades prestigiadas e de redes elitistas de old boys 
(pesquisadores com visões semelhantes à área de pesquisa do avaliador, colegas, amigos).” (BARBOSA, 2016 p.301)

A produtividade e os sistemas de recompensas, pelas agências de fomento e regulação da pós-graduação e da pesquisa no país, traduzem a estratificação social da ciência por meio do julgamento/reconhecimento (ou não) pelos pares e distribuição de recursos, ambos fundamentais para a constituição do pesquisador.

As instituições que apresentamos nesse estudo como instituições do topo da hierarquia no campo científico, da área da Educação, USP, UERJ, UFMG, UNESP, UFRGS e outras em posição de destaque possuem pelo menos um periódico na categoria A1. Tal dado demonstra que possuir um periódico bem qualificado significa chances de participar da definição do que é a qualidade científica esperada pela Capes.

Sobre as vantagens advindas do reconhecimento e da boa posição, França (2014, p.204) ao analisar programas de excelência ressalta a relação do reconhecimento com o conceito de visibility de Bourdieu, acúmulo de uma espécie particular de capital social: o capital de autoridade, afirmando que:

O reconhecimento concedido pelos pares concorrentes é marcado e garantido socialmente por todo um conjunto de sinais específicos de consagração. O reconhecimento desses programas também ficou evidenciado nas falas dos entrevistados, quando mencionam que o fato de terem se tornado Programas de Excelência "abriu portas" dentro e fora de suas instituições. A transferência do reconhecimento do programa para os docentes e discentes que o compõem é ainda um efeito da excelência atestada pela Capes: professores e alunos desses programas são mais respeitados pela comunidade acadêmica e pelas agências de fomento à pesquisa e de concessão de bolsas.

A posição que tais instituições ocupam no sistema de produção e circulação da produção científica e, ao mesmo tempo, da posição que ocupam na hierarquia institucional implicam na posse de capitais cruciais para participação na definição objetiva das regras e das práticas de produção utilizando estratégias de conservação das posições conquistadas. (BOURDIEU, 2007)

Ao priorizarem e conferirem maiores pontuações a determinados tipos de produção científica, mediante a aplicação do Qualis, as agências de fomento reforçam os postos de poder ocupados por cada membro da elite acadêmica. Esse mecanismo de empoderamento e de retroalimentação, de acordo com Bourdieu (2004, 2011c, 2013a, 2013b), viabiliza a acumulação de um tipo específico de capital, mas não impede a conversão e reconversão dele em outros capitais, pois a final, a elite legisla em causa própria quando elabora critérios de inclusão/exclusão ou ainda quando faz das suas medidas a régua para dimensionar o outro. (NASCIMENTO e BUFREM, 2016 p.16) 
Tabela 27 - Instituições nacionais responsáveis pelas revistas Qualis A2

\begin{tabular}{|c|c|}
\hline INSTITUIÇÃO & $\begin{array}{l}\text { QUANTIDADE DE } \\
\text { REVISTAS A2 }\end{array}$ \\
\hline USP & 18 \\
\hline UFRGS & 13 \\
\hline UNESP & 11 \\
\hline PUC-RS & 9 \\
\hline UNICAMP & 7 \\
\hline UEM & 6 \\
\hline Fundação Carlos Chagas & 6 \\
\hline UFRN & 6 \\
\hline UFMG & 6 \\
\hline PUC-PR & 6 \\
\hline UFU & 5 \\
\hline PUC/SP & 4 \\
\hline Estácio de Sá & 4 \\
\hline PUC-CAMPINAS & 4 \\
\hline Associação Brasileira de Psicologia Escolar e Educacional & 4 \\
\hline UNEB & 4 \\
\hline UFMT & 4 \\
\hline FIOCRUZ & 4 \\
\hline UFMA & 3 \\
\hline Associação Brasileira de Saúde Coletiva & 3 \\
\hline UNINOVE & 3 \\
\hline UNISINOS & 3 \\
\hline UnB & 3 \\
\hline UEL & 3 \\
\hline UFSC & 3 \\
\hline Sociedade de Química /USP & 3 \\
\hline UFSM & 3 \\
\hline Universidade Metodista de São Paulo & 2 \\
\hline UNIEVANGÉLICA & 2 \\
\hline Sociedade Brasileira de Pediatria & 2 \\
\hline UEPG & 2 \\
\hline PUC-Rio/ UnB/USP & 2 \\
\hline UFBA & 2 \\
\hline UFV & 2 \\
\hline Colégio Brasileiro de Ciências do Esporte & 2 \\
\hline $\begin{array}{l}\text { Associação Brasileira de Pesquisadores em Educação } \\
\text { Especial/UEL/UNESP }\end{array}$ & 2 \\
\hline INEP & 2 \\
\hline UFPR & 2 \\
\hline UNIFESP & 1 \\
\hline SBC - Sociedade Brasileira de Cardiologia & 1 \\
\hline USP /Sociedade Brasileira de Pesquisa em Odontologia & 1 \\
\hline Sociedade Brasileira para o Progresso da Ciência /UNICAMP & 1 \\
\hline Associação Brasileira de Currículo/UNICAMP & 1 \\
\hline UFF & 1 \\
\hline UFSCAR & 1 \\
\hline Sociedade Brasileira de Medicina Veterinária & 1 \\
\hline Associação Brasileira de Pesquisa Educacional em Ciências & 1 \\
\hline Sociedade Brasileira de Reumatologia & 1 \\
\hline $\begin{array}{l}\text { Associação Nacional de Pós-Graduação em Letras e } \\
\text { Linguística }\end{array}$ & 1 \\
\hline $\begin{array}{l}\text { Total } \\
\end{array}$ & 181 \\
\hline
\end{tabular}

Fonte: banco de dados SOCED / Plataforma Lattes - CNPq, 2016. 
Apenas 8 instituições administram periódicos fora das regiões Sul e Sudeste do país. São 4 instituições do Nordeste e 3 do Centro-Oeste. A visibilidade e credibilidade/autorização científica dada historicamente as instituições pioneiras da pós-graduação das regiões Sul e Sudeste do país tendem a refletir também nos periódicos que acabam sendo melhor qualificados pelos motivos já expressos anteriormente.

As instituições possuírem revistas representa um diferencial no campo do poder. Notamos que a presença de cerca de 15 revistas de associações e sociedades podem indicar um movimento de expansão dos meios de divulgação científica por área temática. Na maioria dos casos, essas associações e sociedades reúnem pesquisadores de diversas instituições com diferentes perspectivas de ciência dentro de áreas temáticas que, por vezes, podem não manter fidelidade direta com modelos científicos de instituições ou linha de pensamento específicas.

Os critérios avaliativos são, em geral, criados por alguns membros da elite científica do campo, enquanto, detentores de um poder autorizado pela comunidade científica. Sobre isso, Nascimento (2016) criticando os critérios de avaliação do Qualis e do CAs do CNPq ressalta mecanismo de empoderamento e retroalimentação.

Ao priorizarem e conferirem maiores pontuações a determinados periódicos através da avaliação Qualis, as agências de fomento reforçam as posições ocupadas por cada membro da elite acadêmica dando bolsas e incentivos aos que já possuem diferencias no campo e dificultando a penetração de pesquisadores de instituições e programas de pós-graduação mais jovens como os do Centro-Oeste, Norte e Nordeste do país.

Pesquisas de França (2014), Barbosa (2016), Nascimento (2016), Leite e Neto (2017) denunciam o caráter homogeneizador das avaliações da Capes para as áreas, subáreas e diferentes regiões do país e ainda destacam a necessidade de editais específicos que diminuam as diferenças regionais e insiram as regiões Norte, Nordeste e Centro-Oeste com mais representatividade do meio acadêmico e científico.

A associação entre mérito e fomento pode causar uma injusta distribuição dos recursos públicos, por favorecer programas e instituições mais bem estruturados que, em geral, conseguem atingir os critérios de qualidade com mais facilidade do que os programas mais frágeis, em termos de recursos, que são 
prejudicados por terem mais dificuldade para atingir as metas estabelecidas (FRANÇA, 2014).

As publicações hoje se tornaram mais do que meio de divulgação científica. Elas também comunicam a realidade de diversos contextos e mobilizam pesquisas e intercâmbios de ideias para o desenvolvimento. Sabemos do potencial e da extensão territorial das regiões mais afastadas do centro do poder e isso não pode ser desconsiderado, mesmo diante das assimetrias existentes no nosso país.

Portanto, a pouca ou não presença de periódicos, assim como a baixa representatividade de PQs, dessas regiões pode dificultar ainda mais a visibilidade dos problemas existentes e do baixo incentivo/financiamento à pesquisa.

A equação é, com efeito, bem mais complexa, envolvendo também esferas de poder como bem trata Ana Paula Hey (2008) ao analisar a relação do espaço acadêmico com a esfera política questionando a falta de autonomia da academia em Ciências Sociais e Humanas em relação à esfera da política. É inegável que a lógica de avaliação, com toda sua carga de subjetividade em torno de uma "crença na verdade científica" (NASCIMENTO, 2016, p.140) ainda privilegia alguns mais familiarizados com as regras e com poder de comando do jogo.

A posição de cada agente nessa estrutura, ou melhor, o peso de cada um para formar essa estrutura e ao mesmo tempo suportá-la, depende de todos os outros pesquisadores, bem como de todos os pontos do espaço e das relações entre todos os pontos. Cada ponto é equivalente a uma posição, sendo que aquela ocupada pelo pesquisador vai restringir ou aumentar o campo dos possíveis que lhe é aberto. (HEY, 2008 p.80)

Nos gráficos 3, 4 e 5 apresentamos a luta pela mobilidade no campo pelos pesquisadores dos níveis $\mathrm{B}, \mathrm{C}$ e $\mathrm{D}$ via volume de publicação nos extratos mais elevados do Qualis os quais analisaremos a seguir observando a subjetividade já mencionada no processo de concessão de recursos e distribuição de bolsas de produtividade. 
Gráfico 3 - Volume da produção distribuído nas respectivas Qualis - PQs-1B

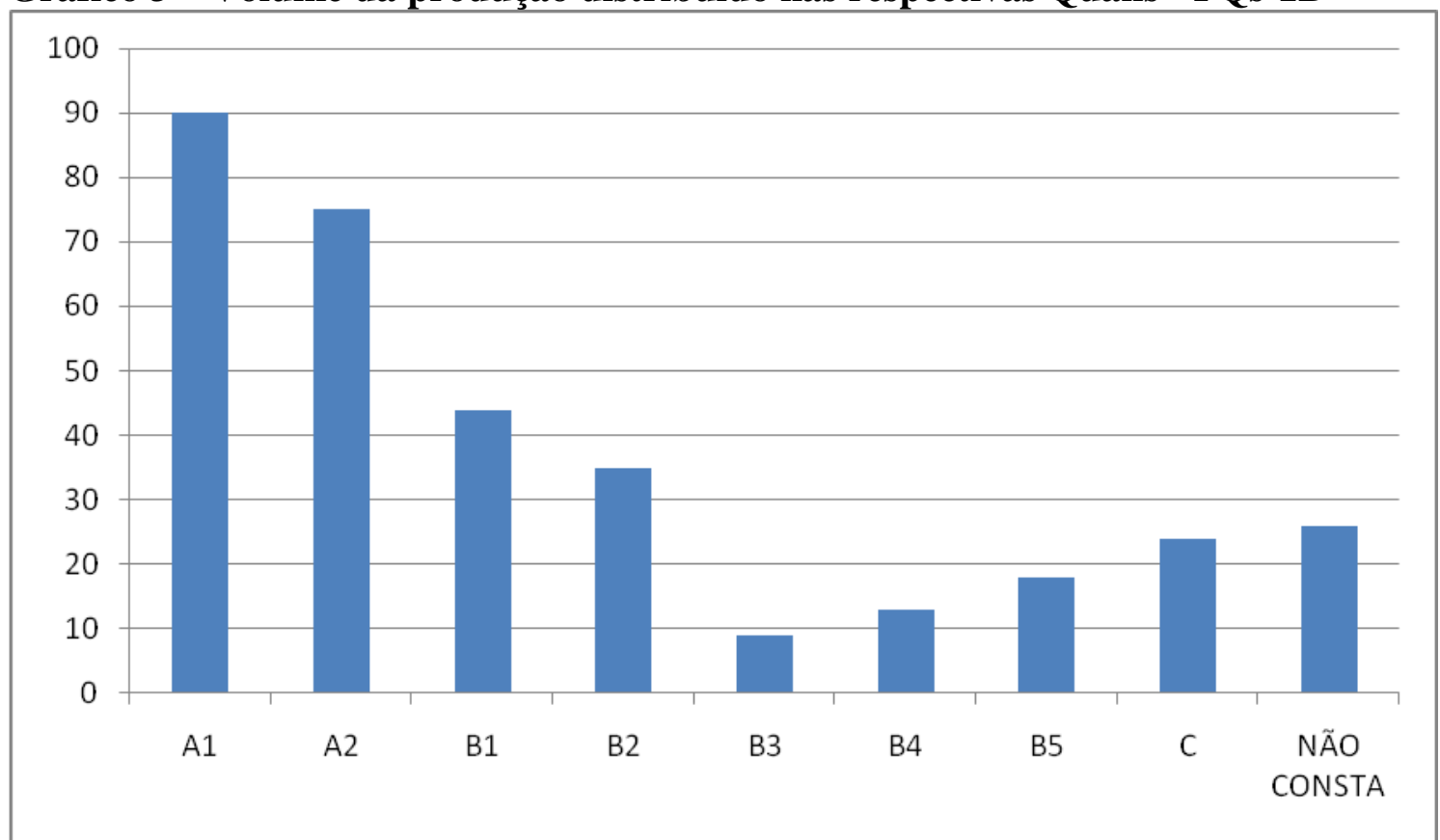

Fonte: banco de dados SOCED / Plataforma Lattes - CNPq, 2016.

Os PQs-1B demonstram com o volume de publicações A1 e A2 desejarem compor a "elite da elite" científica da área lutando para alcançar o nível de PQ$1 \mathrm{~A}$.

Pudemos perceber que em geral há uma dispersão das revistas das publicações com classificações inferiores a B1. Inferimos que esse menor índice de publicações menos qualificadas seja em função do investimento em melhores Qualis e/ou não preocupação em impulsionar periódicos com menores qualificações.

Percebemos que conforme maior o "nome" e a posição do pesquisador como os PQs dos níveis Sr, 1A e 1B, há maior a tendência da carreira solo resguardando-se do empréstimo do nome para publicações com Qualis mais baixas. Sendo assim, dado a responsabilidade com as questões de autoria e originalidade tais PQs nem sempre consideram relevante publicar nos extratos inferiores a B1. Muitas vezes preferem utilizar-se de seus capitais científicos (puro e/ou temporal) para submeter seus trabalhos a revistas bem qualificadas considerando os aspectos relacionados à visibilidade do estudo e possibilidades de citação dos mesmos. E, certamente, a preferência por publicar em revistas científicas bem qualificadas está relacionado a rentabilidade dos periódicos visto seu potencial, dentre os meios de comunicação científica, tanto para que o artigo 
seja acessado (em geral, com mais facilidade que os anais), lido e até mesmo citado aumentando a notoriedade do pesquisador e suas produções acadêmicas.

Gráfico 4 - Volume da produção distribuído nas respectivas Qualis - PQs-1C

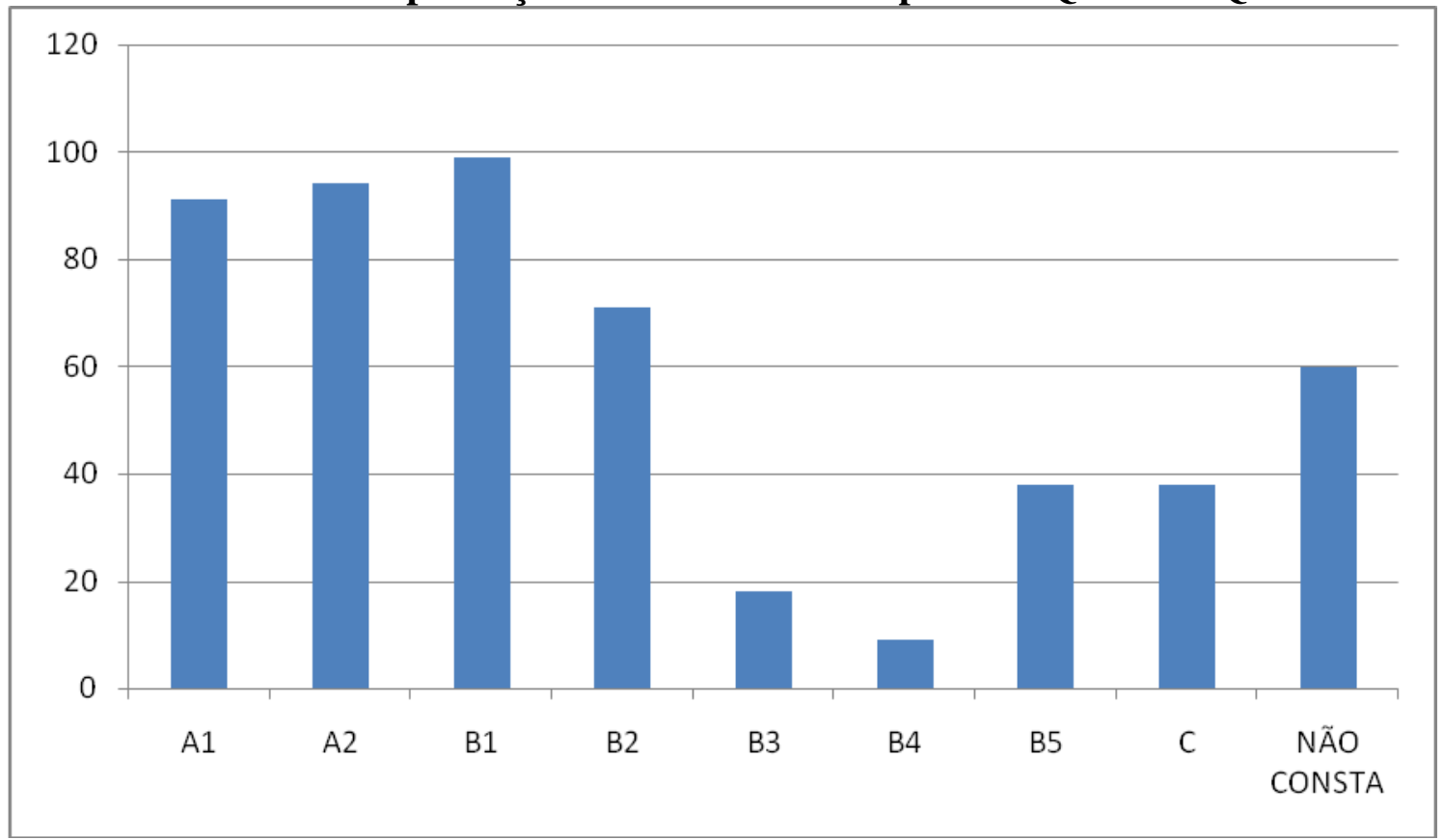

Fonte: banco de dados SOCED / Plataforma Lattes - CNPq, 2016.

Assim como os PQs-1B, os pesquisadores 1C lutam bastante para estarem nas melhores revistas. Apesar da posição intermediária tais pesquisadores demonstram por meio de suas publicações a força de ocupar o campo e buscar reconhecimento.

O conhecimento da posição ocupada neste espaço comporta uma informação sobre as propriedades intrínsecas (condição) e relacionais (posição) dos agentes. Isso vêse particularmente bem no caso dos ocupantes das posições intermediárias ou médias que, além dos valores médios ou medianos das suas propriedades, devem um certo número das suas características mais típicas ao facto de estarem situadas entre os dois pólos do campo, no ponto neutro do espaço, e de oscilarem entre as duas posições extremas. (BOURDIEU, 1998 p.136)

$\mathrm{Na}$ luta por poder classificar e se classificarem dentro da lógica de produtividade produzir para periódicos bem qualificados constitui-se uma estratégia para pontuação nos altos extratos do sistema de avaliação. Notamos que quando publicam em extratos inferiores a B1 são em geral revistas de associações. No caso dos PQs-1C há a Revista de Ensino de Biologia da Associação Brasileira de Ensino de Biologia (SBEnBio) (B2) e o Caderno Brasileiro de Física. Inferimos que publicar nos periódicos de associações possa 
estar relacionado com o poder de tais associações a constituição do "nome próprio"/do reconhecimento do pesquisador.

Gráfico 5 - Volume da produção distribuído nas respectivas Qualis - PQs-1D

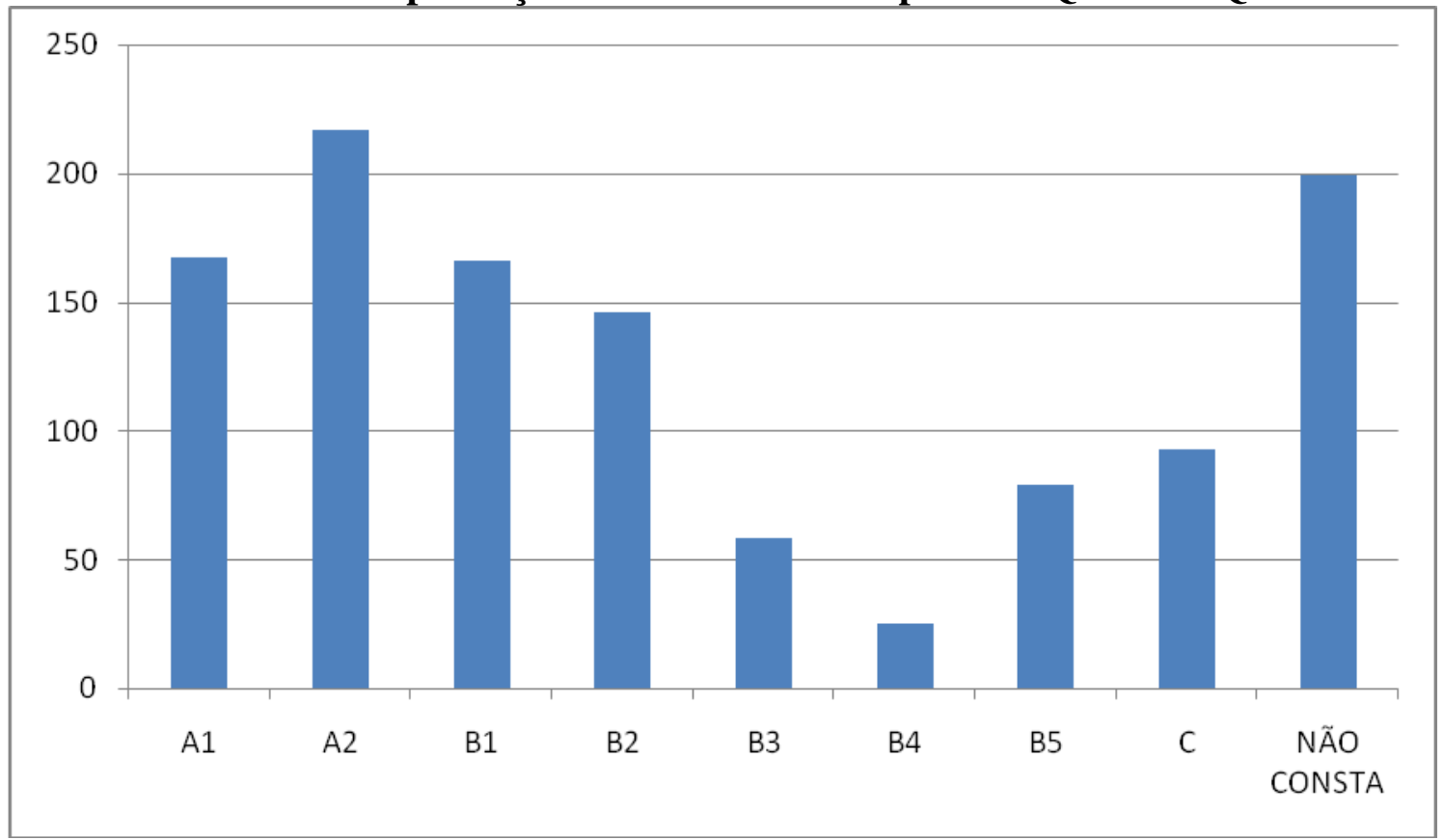

Fonte: banco de dados SOCED / Plataforma Lattes - CNPq, 2016.

Os PQs-1D apresentam um alto volume de publicação em quase todos os extratos, com exceção do B3 e B4, revelando a preocupação em mostrar-se no campo em busca de espaço e reconhecimento científico. O grande volume de publicações internacionais presente na área do "não consta" (157) também pode ser indicativa do engajamento dos pesquisadores em publicar fora do país atendendo as exigências de internacionalização.

Atualmente, diante do valor atribuído às publicações nas avaliações, elas representam possibilidade de lucros simbólicos importantes. Elas são meio de visibilidade e/ou reconhecimento dos pesquisadores já que quanto mais citados, maiores chances têm de serem convidados para comissões, palestras, bancas, dossiês e outros trabalhos que também resultam em acúmulo de capital científico puro e asseguram a reconversão em qualquer outro tipo de capital.

Finalizando a apresentação de dados com a análise dos cinco gráficos que corroboram para toda a tese apresentada, estamos convencidos de que há o interesse da ciência em produzir conhecimento válido para o campo específico. Mas este conhecimento não é nunca desprovido do objetivo de interessar os pares e concorrentes, isto é, produzir efeitos positivos para o campo e para a sua própria 
posição dentro dele. "A busca pela legitimidade individual do agente mas, sobretudo pela legitimidade coletiva do grupo dominante, esbarra na antinomia inerente aos processos de avaliação vigentes" (NASCIMENTO, 2016 p.68)

Como afirma Bourdieu (2004a p.46) “o campo científico é um jogo em que é preciso munir-se de razão para ganhar". É a ordem científica estabelecida que gera uma visibilidade intrínseca do nome que quanto mais conhecido, mais reconhecido e mais vantagens acumula. E estrategicamente as instituições possuírem revistas bem qualificadas possui peso diferencial nesse processo. 


\section{6 \\ Considerações finais}

Toda história do campo social está presente, em cada momento, em forma materializada - em instituições tais como os serviços permanentes de partidos ou de sindicatos - e em forma incorporada- nas atitudes dos agentes que fazem funcionar estas instituições ou as combatem (com os efeitos de histerese ${ }^{65}$ ligados à fidelidade).(BOURDIEU, 1989 p. 156)

O mundo social pode ser dito e construído de diferentes modos como Bourdieu afirma em diversas obras. Em toda pesquisa trabalhamos com uma cadeia de interdependência na qual a posição de cada um definiu a posição de todos hierarquicamente.

Durante toda a pesquisa ao olharmos para a hierarquia institucional demonstramos a predominância de instituições do Sul e Sudeste do país e revelando necessidades de avanço nos sistemas de avaliação e de financiamento.

Resolvemos não caracterizar os pesquisadores, mas apenas as instituições como uma forma de caracterizar o problema das disparidades regionais apresentadas e o poder das instituições na caracterização deste problema.

A estrutura de relações entre os agentes, a posição que cada um ocupa, com sua autoridade relativa, determinam o que pode e não pode ser feito no campo. Nesse sentido, as instituições que possuem posições privilegiadas na hierarquia dos bolsistas de produtividade desfrutam do poder científico que gera legitimidade para boa parte das pautas científicas postas por estas perante as principais agências de regulação e fomento da área, como a Capes e o CNPq. O prestígio científico da instituição e, logo, dos pesquisadores geram forças, no sentido da representatividade e do julgamento dos pares, mesmo que não sejam completamente isentos de subjetividades.

O que vimos no campo científico da Educação são relações de forças institucionais orientadas pelos seus agentes mais bem posicionados, enquanto PQs

\footnotetext{
${ }^{65}$ Histerese é utilizada na teoria de P. Bourdieu para explicar uma defasagem estrutural entre as ocasiões e as disposições. "As categorias de percepção e de apreciação ficariam mal ajustadas às possibilidades objetivas do funcionamento de um campo porque o entorno com o qual se confrontam seria demasiado distante daquele com o qual se ajustam" (CATANI et al., 2017 p.229).
} 
do CNPq, para serem mantidas. Seguindo a lógica do efeito Mateus é o reconhecimento e poder que atrai mais reconhecimento e poder.

As nossas análises evidenciam a existência de um jogo que reproduz a hierarquia de bolsistas e acaba privilegiando instituições que já possuem razoáveis condições de produção de trabalhos científicos mantendo uma dinâmica de maior financiamento das pesquisas além da distribuição de bolsas para seus pesquisadores.

Ambos pesquisador renomado e instituição de prestígio, trabalham no intuito de reforçar seu duplo padrão de excelência; uma vez que espaço das relações no campo científico não é homogêneo, sendo detectáveis estreitas relações entre o lugar que os indivíduos ocupam, as redes sociais a que pertencem e os resultados de pesquisa que produzem. (BARBOSA, 2016. p.300-1)

O poder de regulação e manutenção de recursos pelas agências de fomento são a engrenagem de uma luta política na economia de bens simbólicos onde os capitais científicos puros já não bastam para a manutenção de posições. São necessárias estratégias para capitalização de capitais temporais, isto é, sociais e políticos, por meio da ocupação de posições que permitam a ampliação da rede de reconhecimento que, conforme visto em nossa pesquisa, podem representar trunfos no jogo do campo científico.

O jogo existe porque a intenção de jogá-lo também é dado. "Se a técnica do jogo de xadrez não existisse, eu não poderia ter a intenção de jogar o xadrez" do mesmo modo com a política "a intenção política só se constitui na relação com um estado do jogo político e, mais precisamente, do universo das técnicas de acção e de expressão que ele oferece em dado momento." (BOURDIEU, 1989 p.165)

Nosso estudo nos revelou a centralidade de algumas poucas instituições da região Sul e Sudeste concentrando os recursos para o desenvolvimento da pesquisa em Educação. Mas o que caracteriza, de fato, a distinção das instituições com tantos bolsistas de produtividade? Podemos olhar tal centralização como uma ação inicialmente aleatória que tornou-se estratégica na medida em que foram criados órgãos reguladores e associações com poder político de definição das normas e regras que passaram a conceder distinções a pesquisadores e programas em função das avaliações e ranqueamentos diante das acirradas possibilidades de financiamento. 
As delegações de poder para algumas instituições pioneiras na criação da ANPEd e da pós-graduação pode ter contribuído para legitimidade do poder de julgamento, decisão e contenção dos aspirantes ao campo do poder conjugando interesses com a Capes e o CNPq para manutenção de suas posições, enquanto potenciais definidores para as regras do campo, agregando acumulação de capitais rentáveis no jogo do campo científico.

Especificamente no caso da USP, que tende a prevalecer em todas as dimensões analisadas (formadora de pesquisadores, maioria dos bolsistas de produtividade geral e nas categorias 1A e Sênior e responsável por periódicos), observamos que o grande poder político e a ocupação em diversas esferas do campo científico na área da Educação foi construída diante da obliteração de participação na criação da ANPEd. A USP acabou construindo suas próprias estratégias de entrada e permanência no campo alimentando até hoje um status superior as demais instituições em função do seu poder/ autoridade científica de conceder e retirar vantagens de instituições e pesquisadores.

A exemplo da USP, algumas outras instituições em destaque na hierarquização elaborada possuem a função de condicionar o funcionamento da economia dos bens simbólicos em jogo no campo. Dotadas das atitudes/capitais exigidos pelo campo, elas são capazes de impor os valores no jogo do campo científico na área.

Pudemos constatar que mesmo diante da existência de critérios para as avaliações e concessões de bolsas, os casos "exceções" das bolsas de PQ do CNPq que privilegiam o passado do pesquisador funciona como um aparato acadêmico com utilidades extracientíficas servindo de estratégia para reconhecimento e legitimação de determinados sujeitos, objetos de pesquisa e instituições em detrimento de outros (HEY, 2008).

Em nossa pesquisa pudemos notar o poder das instituições que comandam as regras do jogo e detém estratégias bastante significativas para além da possível pertença a comitês, comissões e cargos políticos. A posse de periódicos bem qualificados representa a legitimidade do fazer científico pelas instituições. As instituições do campo do poder, conforme as tabelas 18 e 19, possuem os periódicos mais disputados pelos pesquisadores para publicação.

Tais instituições possuem esses periódicos bem qualificados pelo Web Qualis como um trunfo do poder e da legitimidade, uma estratégia bem mais 
relevante e pulverizadora de seu poder diante dos pares. São os periódicos que capitalizam notoriedade no campo. São os periódicos que permitem ler e ser lido, citar e ser citado. E dentro desta dinâmica ter nas comissões e nos números de seu periódico pesquisas de algum membro da instituição já é um poder de diferenciação no campo que somado a boa qualificação pelo Qualis torna-se um trunfo, uma estratégia importante tanto para a manutenção da posição da instituição quanto para conservação e ampliação de sua representação perante as agências de fomento que utilizam o Qualis como parâmetro de avaliação de qualidade e excelência.

Embora em nosso estudo tenhamos convergido com pesquisas que demonstram as falhas do potencial avaliativo do sistema Qualis, que têm privilegiado alguns - premiando mais do que incentivando -, devemos ressaltar que as crescentes críticas e pesquisas sobre as bolsas de produtividade são objeto de atenção do CNPq que têm buscado aprimorar sua forma de avaliação.

A exemplo disso, em recente consulta aos critérios do CA de Educação, percebemos a construção de critérios mais claros do que os do ano de 2013-2016 com planilha anexo com pontuação da produção acadêmica para as bolsas 20182020 discriminando os seguintes item: Produção bibliográfica; formação de pesquisadores (orientação); mérito do projeto (incluído o quesito Inovação) e; Gestão acadêmico-científica) ${ }^{67}$.

A luta que opõe os sujeitos são sempre lutas simbólicas pela conservação ou pela transformação de suas posições, ou seja, lutas pelo monopólio da violência simbólica legítima. Considero que esta tese terá cumprido seu papel se o fez pensar que as jogadas e a dificuldade de transpor as barreiras do campo são bem mais do que operações dos pares.

Há uma série de estratégias que vão dos textos de elaboração de políticas avaliativas à comandos de revistas científicas que congregam um halo em torno de algumas instituições que, tendo adquirido investimentos para si, não conseguiriam suportar a ausência deles.

${ }^{66} \mathrm{O}$ site do $\mathrm{CNPq}$ não apresenta um histórico dos critérios para a avaliação da bolsa de produtividade, portanto, para que conheçam como era anteriormente organizado os critérios sugiro a leitura da tese de Nascimento (2016) que dedica parte significativa do trabalho a apresentar critérios de bolsas de produtividade do CNPq assim como do Qualis periódicos e livros.

${ }^{67}$ Ver mais em http://cnpq.br/web/guest/view//journal_content/56_INSTANCE_0oED/10157/5966303. acesso em 1/11/2018. 
Diante da ausência de recursos para todos, a luta concorrencial utiliza-se de estratégias políticas, sociais e científicas. O efeito Mateus é reforçado e cultivado e não o denunciamos como anti-ético, mas como um processo que deve estar cada vez menos presente quando falamos de avaliação e distribuição de recursos. As exceções das concessões de recursos e financiamentos precisam ser criteriosamente estabelecidas sem a carga de subjetividade presente nas redações de seus parâmetros.

Disso se depreende que, por ser uma disfunção social, que reforça o preconceito velado que perpassa e influencia as estruturas sociais e científicas e privilegia o individualismo, o efeito Mateus demanda que os cientistas se auto submetam contínua e humildemente a uma autoavaliação crítica de sua conduta profissional, bem como que favoreçam atitudes mais éticas e inclusivas que nos permitam construir, num futuro próximo, uma ciência eticamente responsável que seja de todos e para todos, e não, uma ciência cega de suas responsabilidades e consequências. Enfim, para se possamos construir uma ciência inclusiva, em que o efeito Mateus seja esquecido e não promova o esquecimento. (BARBOSA, 2016 p.313)

Com efeito, pretendemos com este estudo mostrar que, - apesar das barreiras protetivas de algumas instituições do topo da hierarquia para não perderem seus recursos - há também uma preocupação dos pesquisadores e do próprio sistema de avaliação da Capes e do CNPq em aprimorar e ampliar as possibilidades de participação das diversas regiões do país aumentando o diálogo e o desenvolvimento científico da área da Educação reconhecendo as necessidades e singularidades das diferentes regiões do nosso Brasil. 


\section{Referências bibliográficas}

ALVES, M. F. ; OLIVEIRA, J. F. Pós-Graduação no Brasil: do Regime Militar aos dias atuais. RBPAE, v. 30, n. 2, p. 351-376, 2014.

BALL, S. J. Profissionalismo, gerencialismo e performatividade. Cadernos de Pesquisa, São Paulo, v. 35, n. 126, p. 539-564, set./dez. 2005.

BARBOSA, A. S. Implicações ética do efeito Mateus na ciência. Mediações, Londrina, v.21, n.1, p.286-316, 2016.

BOURDIEU, P. Coisas ditas. São Paulo: Brasiliense, 201104a.

BOURDIEU, P. O mercado de bens simbólicos. In: A economia das trocas simbólicas. São Paulo: Perspectiva, 2007.

BOURDIEU, P. O poder simbólico. Rio de Janeiro: Bertrand, 1989/1998.

BOURDIEU, P. Os usos sociais da ciência: Por uma sociologia clínica do campo científico. São Paulo: Editora UNESP, 2004.

BOURDIEU, P. Para uma sociologia da ciência. São Paulo: Companhia das letras, 2005.

BOURDIEU, Pierre. Elogios da sociologia: discurso de aceitação da medalha de ouro do CNRS. Revista Brasileira de Ciências Sociais, v.28, n.83, p.25-31, 2013.

BOURDIEU. Pierre. Homo academicus. Florianópolis: Ed. da UFSC, 2014.

CAMPOS, M. M.; FÁVERO, O. A pesquisa em educação no Brasil. Cadernos de Pesquisa, São Paulo, n.88, p.5-17, 1994.

CAREGNATO, C. E.; LEITE, D. B. C.; MIORANDO, B. S. Pesquisadores e legitimidade científica no campo da Educação. Linhas críticas, Brasília, v.22, n. 47, p.189-209, 2016.

CATANI, A. M. (Org.) Vocabulário Bourdieu. Belo Horizonte: Autêntica Editora, 2017.

CATANI, A. M. As possibilidades analíticas da noção de campo social. Educação \& Sociedade, v.32, n.114, p.189-202, 2011.

COCK, J. C. A. N.; ANTUNES, A. L.; FERRARO, J. P. et al. Operando com conceitos de Bourdieu: produtividade em pesquisa e hierarquias acadêmicas no campo da educação. Educ. Pesqui. [online], São Paulo, v.44, e178938, p.1-19, 2018.

COENEN-HUTHER, J. Sociologie des elites. Cursus Sociologie. Paris: Armand Colin, 2004.

CUNHA, L. A. Autonomia universitária : teoria e prática. In: VESSURI, H. (Org.) Universidad e investigación científica: convergências y tensiones. Buenos Aires: CLACSO; UNESCO, 2006.

CUNHA, L. A. O desenvolvimento meandroso da educação brasileira entre o estado e o mercado. Educação \& Sociedade, Campinas, vol. 28, n. 100 - Especial, p. 809-829, out. 2007.

CURY, C. R. J. Quadragésimo ano do parecer CFE no 977/65. Revista Brasileira de Educação, n.30, p.7-20, 2005.

FÁVERO, M. L. A.A universidade no Brasil: das origens à Reforma Universitária de 1968. Educar em revista, Curitiba, n.28, p.17-36, 2006.

FERRARO, A. R. A ANPEd, a pós-graduação, a pesquisa e a veiculação da produção intelectual na área da educação. Revista Brasileira de Educação, Rio de Janeiro, n.30, p.47-69, 2005. 
FRANÇA, E. A. Avaliação da Capes e Gestão de Programas de Excelência na Área de Educação. 249 p. Tese de Doutorado. Departamento de Educação, Pontifícia Universidade Católica do Rio de Janeiro, Rio de Janeiro, 2014.

GATTI, B. A. Implicações e perspectivas da pesquisa educacional no Brasil contemporâneo. Cadernos de Pesquisa, n.113, p.65-81, 2001.

GATTI, B. A. Pós-graduação e Pesquisa em Educação no Brasil 1978-1981. Cadernos de Pesquisa, n.44, p. 1-17, 1983.

GOUVEIA, F. C. F. A institucionalização da pós-graduação no Brasil: o primeiro decênio da Capes (1951-1961). RBPG, Brasília, v. 9, n. 17, p. 373 - 397, julho de 2012

GUEDES, M. de C.; AZEVEDO, N.; FERREIRA, L. O. A produtividade científica tem sexo? Um estudo sobre bolsistas de produtividade do CNPq. Cadernos Pagu, n. 45, p.367-399, 2015.

HENRIQUES, V. M. P. de M. ANPEd e a preocupação da autonomia: em busca de reconhecimento e consagração. Tese de Doutorado. 191f. Pontifícia Universidade Católica do Rio de Janeiro. Rio de Janeiro, 1998.

HEY, A. P. Esboço de uma sociologia do campo acadêmico: a educação superior no Brasil. São Carlos: EdUFSCar, 2008.

LEITE, A. C. F. ; NETO, I. R. Perfil dos bolsistas de produtividade em pesquisa do CNPq em Educação. Revista Brasileira de Ensino Superior, v.3, n.4, 2017.

LIMA, Denise M. de Oliveira. Campo do poder, segundo Pierre Bourdieu. Cógito, Salvador, n. 11, p. 14-19, out. 2010.

MENDONÇA, A. W. P. C. A formação dos mestres: a contribuição de Anísio Teixeira para a institucionalização da pós-graduação no Brasil. In: Seminário "Um olhar sobre Anísio Teixeira" Mesa Redonda "Política Educacional", Rio de Janeiro, 3 de sete. 1999. Rio de Janeiro. UFRJ/CFCH/PACC/, Fundação Anísio Teixeira, 1999.

MERTON, R. K. The Matthew Effect in Science: The reward and communication systems of science are considered. Science, v. 159, n. 3810, p.56-63, jan. 1968.

MORITZ, G.de O.; MORITZ, M. O.; MELO, P. A. A Pós-Graduação brasileira: evolução e principais desafios no ambiente de cenários prospectivos. Disponível em:https://repositorio.ufsc.br/bitstream/handle/123456789/26136/5.30.pdf?sequen $\mathrm{ce}=1 \&$ isAllowed $=\mathrm{y}$. Acesso: $28 / 12 / 2018$.

NASCIMENTO, B. S. A produção científica dos bolsistas de produtividade do CNPQ: trajetórias da elite consagrada no campo da Educação no Brasil. Tese de doutorado. 216f. Programa de Pós-Graduação em Educação da Universidade Federal do Paraná, 2016.

NASCIMENTO, B. S.; BUFREM, L. S. Histórias e trajetórias: uma análise da produção científica da elite consagrada no campo da educação no Brasil. Encontro Nacional de Pesquisa em Ciência da Informação, v. 17, 2016.

PETERS, G. Habitus, reflexividade e neo-objetivismo na teoria da prática de Pierre Bourdieu. Revista Brasileira de Ciências Sociais, v.28, n.83, p.47-71, 2013. RODRIGUES, L. O. C. Publicar mais, ou melhor? O tamanduá olímpico. Psicol. USP, São Paulo, v.22, n.2, p. 457-472, São Paulo, 2011.

ROMANI, J. P. O Conselho Nacional de Pesquisas e institucionalização da Pesquisa Científica no Brasil In: SCHWARTZMAN, S. (org.) Universidades $e$ Instituições Científicas no Rio de Janeiro. Conselho Nacional de Desenvolvimento Científico e Tecnológico (CNPq). Brasília. p.135-166, 1982. Disponível em: http://www.schwartzman.org.br/simon/rio/jacqueline.htm. 
SANTOS, A. L. F. dos; AZEVEDO, J. M. L. de. A pós-graduação no Brasil, a pesquisa em educação e os estudos sobre a política educacional. Revista Brasileira de Educação, Rio de Janeiro, v. 14, n. 42, p.534-550, 2009.

SAVIANI, D. A pós-graduação em Educação no Brasil: trajetória, situação e perspectiva. Revista Diálogo Educacional, Paraná, v.1, n.1, p.1-19, 2000.

SAVIANI, D. O legado educacional do regime militar. Caderno Cedes, Campinas, vol. 28, n. 76, p. 291-312, set./dez. 2008.

SAVIANI, D. O protagonismo do professor Joel Martins na pós-graduação. Revista Brasileira de Educação, n.30, p.21-35, 2005.

SCHWARTZMAN, S. A universidade primeira do Brasil: entre intelligentsia, padrão internacional e inclusão social. Estudos Avançados, São Paulo, v.20, n.56, p.161-189, 2006. Disponível em: http://www.scielo.br/scielo.php?script=sci_arttext\&pid=S0103-

40142006000100012 . Acesso em: 8/11/2017.

SILVA, L. L. Estudo do Perfil Científico dos Pesquisadores com Bolsa de Produtividade do CNPq que atuam no Ensino de Ciências e Matemática. Revista Brasileira de Pesquisa em Educação em Ciências, v. 11, n. 3, 2011.

VICTOR, A. D. Desigualdade e estratificação social: um estudo de caso sobre o Efeito Mateus a partir da Bolsa de Produtividade em Pesquisa do Conselho Nacional de Desenvolvimento Científico e Tecnológico para o campo da Sociologia (2002/2012). Tese de Doutorado. 219f. Instituto de Ciências Sociais, Departamento de Sociologia, Universidade de Brasília, 2014.

WACQUANT, L. Bourdieu 1993: um estudo de caso em consagração científica. Revista Brasileira de Ciências Sociais, v.28, n.83, p.33-46, 2013.

WAINER, J.; VIEIRA, P. Avaliação de bolsas de produtividade em pesquisa do $\mathrm{CNPq}$ e medidas bibiométricas: correlação para todas as grandes áreas. Perspectivas em Ciência da Informação, v.18, n.2, p.60-78, 2013. 


\section{Apêndices}

8.1

Apêndice 1- Relação entre nível do bolsista de produtividade e a publicação em periódicos no triênio (2013-2016) por instituição

*Legenda:

\begin{tabular}{|c|c|c|c|}
\hline \multirow{2}{*}{$\mathrm{PQ} 1 \mathrm{~A}$} & \multicolumn{2}{|c|}{$P Q 1 B$} & \multirow[t]{2}{*}{$P Q 1 D$} \\
\hline & $\mathrm{POSr}$ & PQ 1C & \\
\hline & INSTITUIÇÃO & $\begin{array}{l}\text { NÚMERO } \\
\text { PERIÓ| }\end{array}$ & $\begin{array}{l}\text { E PUBLICAÇÕES EM } \\
\text { ICOS NO TRIÊNIO } \\
(2013-2016)\end{array}$ \\
\hline & UFRGS & & 88 \\
\hline & UNIFESP & & 45 \\
\hline & UFBA & & 44 \\
\hline & UFRJ & & 42 \\
\hline & UEL & & 41 \\
\hline & UFSCAR & & 41 \\
\hline & UFRGS & & 38 \\
\hline & UEL & & 37 \\
\hline & UEM & & 33 \\
\hline & UERJ & & 33 \\
\hline & UNEB & & 32 \\
\hline & UNESP & & 30 \\
\hline & UNICAMP & & 30 \\
\hline & FURG & & 28 \\
\hline & UFMG & & 28 \\
\hline & UFES & & 27 \\
\hline & UFPR & & 26 \\
\hline & UFRGS & & 25 \\
\hline & UFSCAR & & 25 \\
\hline & UERJ & & 24 \\
\hline & UNESP & & 24 \\
\hline & USP & & 24 \\
\hline & PUC-RS & & 22 \\
\hline & UECE & & 22 \\
\hline & UNESP & & 22 \\
\hline & UFF & & 21 \\
\hline & USP & & 21 \\
\hline & PUC-RS & & 20 \\
\hline & UNESP & & 20 \\
\hline & UNIFESP & & 20 \\
\hline & UEM & & 19 \\
\hline
\end{tabular}




\begin{tabular}{|c|c|}
\hline UFMG & 19 \\
\hline UFPR & 19 \\
\hline UFRGS & 19 \\
\hline UFRJ & 19 \\
\hline UNB & 19 \\
\hline UNICAMP & 19 \\
\hline UNISINOS & 19 \\
\hline UERJ & 18 \\
\hline UFU & 18 \\
\hline UNISINOS & 18 \\
\hline UFC & 17 \\
\hline UFPEL & 17 \\
\hline UFSC & 17 \\
\hline UFU & 17 \\
\hline UNESP & 17 \\
\hline UFRGS & 16 \\
\hline UNESP & 16 \\
\hline UNESP & 16 \\
\hline UNICAMP & 16 \\
\hline UNICAMP & 16 \\
\hline UNISINOS & 16 \\
\hline UERJ & 15 \\
\hline UFMG & 15 \\
\hline UFMG & 15 \\
\hline UFRJ & 15 \\
\hline UFU & 15 \\
\hline UNESP & 15 \\
\hline UNESP & 15 \\
\hline PUC-GOIÁS & 14 \\
\hline UEPG & 14 \\
\hline UFF & 14 \\
\hline UFMG & 14 \\
\hline UFPA & 14 \\
\hline UFSCAR & 14 \\
\hline UFSCAR & 14 \\
\hline UNESP & 14 \\
\hline UNESP & 14 \\
\hline PUC-RIO & 13 \\
\hline PUCRS & 13 \\
\hline PUC-RS & 13 \\
\hline PUC-SP & 13 \\
\hline UFF & 13 \\
\hline UFRGS & 13 \\
\hline
\end{tabular}




\begin{tabular}{|c|c|c|}
\hline & UFRJ & 13 \\
\hline & UNICAMP & 13 \\
\hline & UNISINOS & 13 \\
\hline & PUC-SP & 12 \\
\hline & UERJ & 12 \\
\hline & UERJ & 12 \\
\hline & UFMG & 12 \\
\hline & UFPR & 12 \\
\hline & UFRGS & 12 \\
\hline & UFRGS & 12 \\
\hline & UFRJ & 12 \\
\hline & UFRN & 12 \\
\hline & UFSCAR & 12 \\
\hline & UFSCAR & 12 \\
\hline & UFSM & 12 \\
\hline & UFU & 12 \\
\hline & UNICAMP & 12 \\
\hline & UNICAMP & 12 \\
\hline 巳 & UNISINOS & 12 \\
\hline ర్ & USP & 12 \\
\hline & PUC-SP & 11 \\
\hline 总 & UERJ & 11 \\
\hline & UFPB & 11 \\
\hline & UFRGS & 11 \\
\hline & UFRGS & 11 \\
\hline & UFSC & 11 \\
\hline & UNICAMP & 11 \\
\hline & UNIFESP & 11 \\
\hline & USP & 11 \\
\hline & UERJ & 10 \\
\hline & UERJ & 10 \\
\hline & UFAL & 10 \\
\hline & UFPB & 10 \\
\hline & UFRGS & 10 \\
\hline & UFRJ & 10 \\
\hline & UNISINOS & 10 \\
\hline & USP & 10 \\
\hline & PUC-RIO & 9 \\
\hline & PUC-SP & 9 \\
\hline & UFMG & 9 \\
\hline & UFRGS & 9 \\
\hline & \begin{tabular}{|l|} 
UFSCAR \\
\end{tabular} & 9 \\
\hline & UFSCAR & 9 \\
\hline
\end{tabular}




\begin{tabular}{|c|c|}
\hline UNISINOS & 9 \\
\hline USP & 9 \\
\hline USP & 9 \\
\hline USP & 9 \\
\hline UFBA & 8 \\
\hline UFMG & 8 \\
\hline UFMG & 8 \\
\hline UFSCAR & 8 \\
\hline UFSM & 8 \\
\hline USP & 8 \\
\hline UERJ & 7 \\
\hline UFC & 7 \\
\hline UFMG & 7 \\
\hline UFPE & 7 \\
\hline UFRJ & 7 \\
\hline UFRN & 7 \\
\hline UFSCAR & 7 \\
\hline UFSCAR & 7 \\
\hline UNESP & 7 \\
\hline UNESP & 7 \\
\hline USP & 7 \\
\hline USP & 7 \\
\hline USP & 7 \\
\hline USP & 7 \\
\hline USP & 7 \\
\hline USP & 7 \\
\hline USP & 7 \\
\hline PUC-RS & 6 \\
\hline PUC-RS & 6 \\
\hline PUC-SP & 6 \\
\hline UFF & 6 \\
\hline UFMG & 6 \\
\hline UFMG & 6 \\
\hline UFPE & 6 \\
\hline UFRGS & 6 \\
\hline UFSC & 6 \\
\hline UFSCAR & 6 \\
\hline USP & 6 \\
\hline UTP-PR & 6 \\
\hline UERJ & 5 \\
\hline UFC & 5 \\
\hline UNB & 5 \\
\hline UNESP & 5 \\
\hline
\end{tabular}




\begin{tabular}{|l|c|}
\hline UERJ & 4 \\
\hline UERJ & 4 \\
\hline UFMG & 4 \\
\hline UFMG & 4 \\
\hline UFRJ & 4 \\
\hline UFRN & 4 \\
\hline UFSC & 4 \\
\hline PUC-RIO & 3 \\
\hline UERJ & 3 \\
\hline UFBA & 3 \\
\hline UFPR & 3 \\
\hline UFRJ & 3 \\
\hline USP & 3 \\
\hline USP & 3 \\
\hline PUC-RIO & 2 \\
\hline UNB & 2 \\
\hline USP & 2 \\
\hline UFJF & 1 \\
\hline USP & 1 \\
\hline PUC-CAMPINAS & 0 \\
\hline USP & 0 \\
\hline \multicolumn{1}{|c|}{ 181 PQS } & 2457 publicações em periódicos \\
\hline
\end{tabular}

Fonte: banco de dados SOCED / Plataforma Lattes - CNPq, 2016. 


\section{2}

\section{Apêndice 2 - Média da Idade científica}

\begin{tabular}{|c|c|c|}
\hline $\begin{array}{c}\text { Categoria } \\
\text { dos PQs }\end{array}$ & $\begin{array}{c}\text { Média da } \\
\text { idade } \\
\text { científica }\end{array}$ & $\begin{array}{c}\text { Menor e maior } \\
\text { ano de ingresso na } \\
\text { instituição }\end{array}$ \\
\hline 1A & 28,56 & $1968 / 1999$ \\
\hline SR & 37,90 & $1972 / 1984$ \\
\hline 1B & 24 & $1977 / 2005$ \\
\hline 1C & 21,38 & $1983 / 2002$ \\
\hline 1D & 19,44 & $1984 / 2006$ \\
\hline
\end{tabular}

Fonte: banco de dados SOCED / Plataforma Lattes - CNPq, 2016. 